\title{
The Long and The Short: Portfolio Turnover Ratios \& Mutual Fund Investment Time Horizons
}

\begin{abstract}
Anne M. Tucker*
Mutual fund portfolio turnover ratios (PTR) are at the center of the short-termism debate, which criticizes corporate maneuvers taken to prop up near-term earnings at the expense of long-term, value focused investments and policies. Scholars and policymakers often rely on portfolio turnover ratios to argue that mutual fund short-termism, as measured by the PTR, is increasing and infecting operating company time horizons. This article answers two main questions central to discerning mutual funds' role in the shorttermism debate. The first is, how long, on average do U.S. registered mutual funds hold onto their assets? The second is, how good of a measure is the PTR at approximating mutual fund holding patterns in light of criticisms that the PTR is an indirect measure, does not reflect fund flows, and excludes investment strategy considerations?

Using a unique data set of U.S. registered mutual funds from 2005-15, this Article finds that mutual fund investment time horizons, as measured by portfolio turnover ratios, did not decline during 2005-15. This finding holds for all major categories of mutual funds, including index funds and actively managed funds and produced an average holding period in the range of fifteen to seventeen months. Based on this analysis, scholars and policymakers may think of mutual fund investment time horizons as short, but not shortening. These findings are confirmed by three alternative measurements of time horizons: Duration, Churn Rates, and Modified Portfolio Turnover. Consistent acrossmeasure results mitigate PTR criticisms as a rough estimate of time horizons and endorse its continued use in SEC reporting. These observations also validate policymakers' and scholars' use of mutual fund PTRs in legal and policy debates, and contribute current, empirical evidence adding nuance to claims of mutual fund short-termism.
\end{abstract}

\footnotetext{
*Anne M. Tucker, Associate Professor of Law, Georgia State University College of Law. The careful work of Honglin Ren, GSU Robinson College of Business, Ph.D. candidate in Finance \& Alicia Plemmons, GSU Andrew Young School of Public Policy, Ph.D. candidate in Economics contributed immeasurably to the creation and analysis of the dataset described herein. Ryan DelCampo and Holly van den Toorn's legal research skills also advanced this work. I express gratitude to all who reviewed working drafts of the Article including members of the Institutional Investor Roundtable, dedicated faculty at the University of Florida as a part of their faculty speakers' series and colleagues at Georgia State University College of Law. Individuals' whose edits and conversations advanced my thinking in significant ways include Frank Partnoy, Mark Roe, Jessie Fried, Anita Krug, Alan Palmiter, William Birdthistle, Jon Lukomnik, Jordan Barry, Steven Davidoff Solomon, Dan Sokol, Jennifer Taub, Bill Bratton, Martijn Cremers, and Chuck O'Kelley. All mistakes are my own.
} 


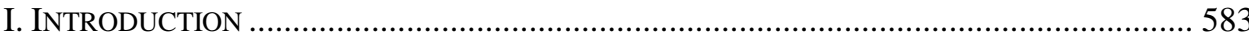

II. PORTFOLIO TURNOVER RATIO: U.S. CALCULATION AND USES ................................. 587

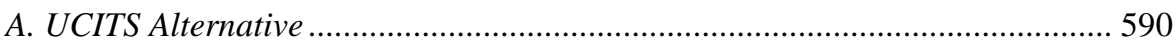

III. PortFolio Turnover Ratio Data In Public DEBATES ....................................... 590

A. The Portfolio Turnover Ratio Signal Strength \& Criticisms ........................... 591

1. Time Horizon \& Transaction Cost Estimates............................................ 591

2. Common Critique: Strategy \& Liquidity ................................................. 593

3. Common Critique: Round Trip Trades ................................................ 595

4. Common Critique: Asset Classes \& Rare Events ..................................... 596

5. Common Critique: Tax-Specific Concerns............................................. 596

B. PTR Uses ....................................................................................................... 597

1. A Literature Review of PTR ....................................................................... 597

a. PTR in Legal Literature ..................................................................... 597

b. PTR as Investment Time Horizon Estimate ........................................... 598

c. PTR as a Transaction Cost Estimate ...................................................... 599

d. Limitations of Portfolio Turnover Ratio Calculations............................ 600

e. Law \& Policy .......................................................................................... 600

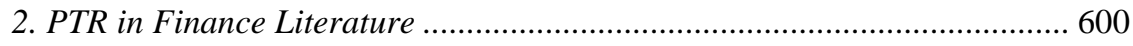

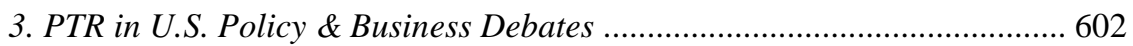

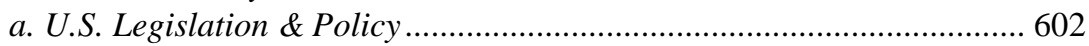

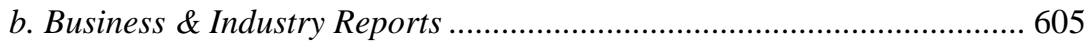

IV. REMEASURING PORTFOLIO TURNOVER RATIOS ................................................ 607

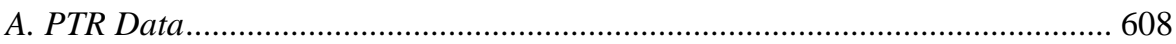

B. Mutual Fund Time Horizon PTR Re-measurement Methodology ................... 611

1. Overview of Measure .............................................................................. 611

2. General Portfolio Turnover Ratio Trends ..................................................... 612

3. Trends by Fund Cap \& Style Codes ............................................................ 615

C. Robustness Checks: Alternative Measures of Mutual Fund Investment Time

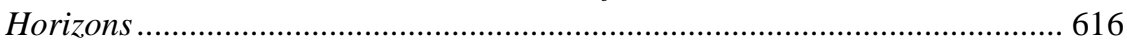

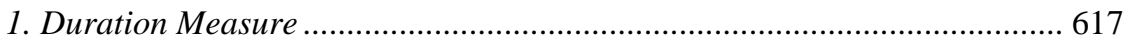

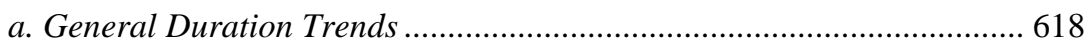

b. Duration Trends by Style and Cap Codes ............................................ 620

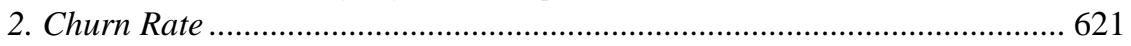

a. Churn Rate General Trends ............................................................. 623

b. Churn Rate Trends by Fund Style \& Cap Codes .................................. 624

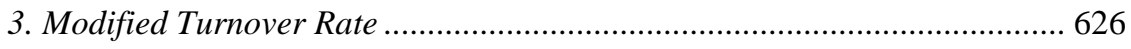

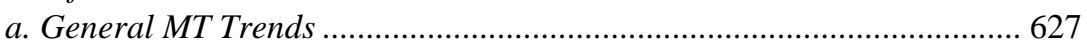

b. MT Trends by Fund Style and Cap Codes ................................................629

V. DATA DiSCUSSION ................................................................................................. 629

A. Average Holding Periods PTR \& Alternative Measures ................................. 629

B. Signal Strength: Relationship Between PTR \& Alternative Measures ............. 630

1. Limitations of Empirical Observations ..................................................... 633

C. Mutual Fund Turnover Report \& Time Horizon Estimate

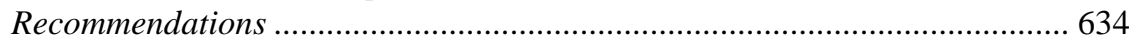

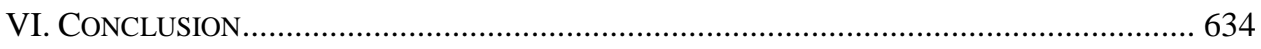

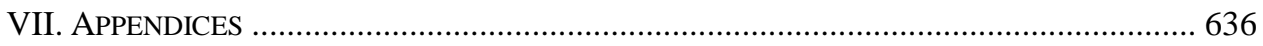




\section{A. Appendix 1: Top 10 Public Companies by Market Capitalization \& Top 10} Institutional Holders.

\section{INTRODUCTION}

Mutual fund investment time horizons are central to the short-termism debate. ${ }^{1}$ Shorttermism is a general, negative diagnosis for an inappropriate and unjustified focus on shortterm gains or earnings, usually measured in quarters, over long-term returns. ${ }^{2}$ Using a unique dataset, this Article evaluates the investment time horizons of all U.S. registered mutual funds from 2005-2015 using the SEC reported metric of portfolio turnover ratios (PTR) and three alternative measures developed in the finance literature: Duration, Churn Rate, and Modified Portfolio Turnover. With this dataset, I contribute to two foundational inquiries. First, how long, on average, do mutual funds hold onto their assets? Second, how good of a measure is the PTR at approximating mutual fund holding patterns?

As I demonstrate below, the assumption that mutual fund investor time horizons have been shortening during the past decade are incorrect. They are short - in the range of fifteen to seventeen months - but not shortening. Rather, mutual fund time horizons have remained relatively constant, between 2005 and 2015, with evidence of increased holding periods following the financial crisis. These findings are consistent across three of the four measures ${ }^{3}$ and analyzed across different mutual fund market segments.

Recent empirical data on mutual fund holding patterns add nuance to a common narrative attributing corporate short-term performance pressures to institutional investors,

1. Other institutional investors, activist hedge funds, and high frequency traders all contribute to the shorttermism debate. See Luis A. Aguilar, Comm'r, SEC, Speech at Georgia State University, Institutional Investors: Power \& Responsibility (Apr. 19, 2013), https://www.sec.gov/news/speech/2013-spch041913laahtm ("The universe of institutional investors includes mutual funds and ETFs regulated by the SEC, as well as pension funds, insurance companies, and a wide variety of hedge funds and managed accounts."); John C. Coffee Jr. \& Darius Palia, The Impact of Hedge Fund Activism: Evidence and Implications 38-40 (European Corp. Governance Inst. (ECGI), Working Paper No. 266/2014, 2014), https://papers.ssrn.com/sol3/papers.cfm?abstract_id=2496518 (discussing activist hedge funds relationship with short-termism); STEPHEN DAVIS ET AL., WHAT THEY Do WITH Your Money: How the Financial System Fails Us AND How to FIX IT 52 (2016) ("High-frequency computer driven trading is estimated to account for 61 percent of all stock market trades in the United States.").

2. "Short-termism or myopia can be defined as the focus of investors and managers on short-term gains, whether quarterly earnings or short-term portfolio returns, at the expense of long-run shareholder value." Dionysia Katelouzou, Myths and Realities of Hedge Fund Activism: Some Empirical Evidence, 7 VA. L. \& Bus. REv. 459, 477 (2013). See also Danyelle Guyatt \& Jon Lukomnik, Does Portfolio Turnover Exceed Expectations? 3 RotMAn InTERNT'L J. PENSION MGMT 40, 40-45 (2010) (defining short-termism in asset managers as "an average holding period of twelve months or less" but noting the "arbitrary" cut off of twelve months). For a discussion of contributing attributes, like information asymmetry, see K.J. Martijn Cremers \& Simon Sepe, Institutional Investors, Corporate Governance and Firm Value, 41 SeATTLE U. L. REV. 387, 393-95 (2018).

3. The Churn Rate produced an estimated average holding time of 10-12 months. The results of this measure and the others are discussed in Part IV. 
including mutual funds. ${ }^{4}$ Scholars posit that institutional investors' narrow focus on quarterly earnings favors corporate actions with near-term benefits, regardless of long-term effect. ${ }^{5}$ Institutional investor pressure, ${ }^{6}$ particularly from mutual funds, can permeate and infect operating company time horizons. To illustrate the reach and depth of mutual fund holdings, see Appendix 1 summarizing the top unaffiliated holders of stock in the top-ten market capitalization, public companies. ${ }^{7}$ Funds' quarterly earning preoccupation and anxiety may feed the quarterly anxiety of corporate boards of directors. Mutual fund shorttermism may encourage corporate maneuvers to prop up short-term value, eroding longterm value-enhancing investments. ${ }^{8}$ Short-termism is seen as a contagion that can spread from funds to firms.

The short-termism debate is a subtext to discuss corporate control, governance norms, and the role of markets. ${ }^{9}$ Scholars sympathetic to negative short-termism claims propose an antidote of increased corporate board control to insulate managers from the pressures of

4. There are several versions of the short-termism narrative, which has a storied history. Consider legal scholar Mark Roe, who engaged with the short-termism debate in 1991 and again in 2013. Mark J. Roe, A Political Theory of American Corporate Finance, 91 Colum. L. REV. 10, 13 (1991) ("Modern writers blame corporate mismanagement on shareholders, who they say value short-run profits excessively, to the detriment of the nation. They claim that managers would take the long-view but are stymied by Wall Street's short-run goals; companies shun long-term investment, and industry underinvests in research and development.").

5. Mutual fund short-termism is attributed, in part, to fund manager payment schemes-where managers receive a percentage of total assets under management - and resulting pressures to keep investors in the fund through the enticement of high quarterly earnings. See, e.g., Lynne Dallas, Short-Termism, the Financial Crisis and Corporate Governance, 37 J. CORP. L. 265, 317 (2012) (describing payment incentives).

6. "In practice, short-termism is manifested in the form of two distinct but inter-locking general practices. The first of these practices is investor short-termism, and the second is managerial short-termism. ...[T]he second dimension of short-termism typically arises in response to the first, given the general responsiveness of corporate managers to perceived stock market signals." Marc T. Moore \& Edward Walker-Arnott, A Fresh Look At Stock Market Short-Termism, 41 J.L \& Soc. 416, 423-24 (2014) (discussing managerial short-termism on pages 427432); see also David Millon, Shareholder Social Responsibility, 36 SeATTLE U.L. Rev. 911, 915-16 (2013) (describing short-term institutional investor pressures on corporate managers).

7. All U.S. mutual funds are required by federal tax and investment company laws to be "diversified entities. Generally speaking, with respect to $75 \%$ of the fund's assets, no more than $5 \%$ may be invested in the securities of any one issuer (company), which means that twenty-five percent of a fund's assets may be more concentrated. 15 U.S.C. $§ 80 a-5$ (2017). IRS regulations impose a maximum ten percent investment cap in the "outstanding voting securities" of any one issuer. 26 U.S.C. § 851(e)(2) (2017) (commonly referred to as subchapter M of IRS code requiring mutual fund diversification); see also Comprehensive Regulatory Regime for U.S. Mutual Funds, ICI 3 (2014), https://www.ici.org/pdf/14_ici_usfunds_regulation.pdf (discussing diversification requirements).

8. Jonathan Bailey \& Jonathan Godsall, Focusing Capital on the Long Term, Short-Termism: Insights from Business Leaders, SHAREHOLDER F. 3 (Dec. 26, 2013),

www.shareholderforum.com/access/Library/20131226_McKinsey.pdf (describing increased pressure to produce short-term performance among boards of directors and institutional investors); $c f$. George W. Dent, Jr., The Essential Unity of Shareholders and the Myth of Investor Short-Termism, 35 DEL. J. CORP. L. 97, 128 (2010) ("The charge that myopic shareholders force short-termism on farsighted managers seems not only wrong but backwards. To the extent that myopia is a problem, it stems from the managers, not the shareholders.").

9. Who is or should be investing in the short term or the long term is a question that has deep intellectual roots in the corporate governance quest for the appropriate balance of power. Mark J. Roe, Corporate ShortTermism - In the Boardroom and Courtroom, 68 BuS. LAw. 977, 979 (2013) [hereinafter Roe, Corporate ShortTermism] ("Over the years, the chairs of the Securities and Exchange Commission, Congress, business analysts, and the business media have regularly excoriated trading markets as perniciously shortening corporate time horizons, justifying corporate law rules insulating boards from markets.”). 
greedy, short-term orientated investors. ${ }^{10}$ Opposing scholars highlight short-term investors' ability to unlock firm value and counter corporate management long-term bias, or myopia. Proponents draw from competitive market pricing efficiency theories so that long-term beneficial actions are priced into current prices as are value detracting time irrationalities like short-termism. ${ }^{11}$ Promoting shareholder voting rights and activism is consistent with this view. ${ }^{12}$ Identifying the cause or causes of an inappropriately shortterm time horizon is necessary, and preliminary, to identifying any solutions.

The short-termism debate is not purely academic. Legislators and practitioners have proposed legal and policy solutions reflective of the first narrative that institutional investors' short-termism negatively infects corporate management time horizons. ${ }^{13}$ Mutual funds control $\$ 15.7$ trillion in assets, own $31 \%$ of U.S. public companies, and are the primary retirement savings vehicle for 93 million Americans. ${ }^{14}$ Mutual funds are major market participants; they influence operating companies; and, they are a foundation of our national retirement policy and individual financial security. ${ }^{15}$ All mutual fund investors bear the direct costs of portfolio turnover through transaction fees like commissions and taxes. All mutual fund investors also bear the indirect costs of any negative market externalities generated by short termism. ${ }^{16}$ If tomorrow's future is mortgaged for today's gain, this is a costly gamble for too many working Americans saving for retirement.

Each of the preceding paragraphs implicate a rich and divisive body of literature that the footnotes cursorily address. For purposes of this Article, it does not matter whether you believe that short-term pressures within funds permeate into the operating company's consciousness or whether the funds' transferred time horizon encourages value reducing operating company decisions. This Article asks a more foundational question: what do we know about mutual fund time horizons and are they increasingly short-term? If so, the contagion narrative gains prominence and support. If not, the short-termism narrative lacks nuance and invites revision.

10. See, e.g., Dominic Barton, Capitalism for the Long Term, HARV. Bus. Rev. (Mar. 2011) https://hbr.org/2011/03/capitalism-for-the-long-term (arguing that to combat short-termism, part of a three pronged- strategy should include "bolstering boards ability to govern like owners").

11. See, e.g., Cremers \& Sepe, supra note 2, at 395-98 (providing a thoughtful summary of the relationship between information efficient market pricing and the short-termism debate).

12. See, e.g., Lucian A. Bebchuk, The Myth that Insulating Boards Serves Long-term Value, 113 CoLuM L. REV. 1637 (2013) (dismissing the value of board insulation and advocating for shareholder engagement through voting and mechanisms to hold corporate boards of directors accountable).

13. See, e.g., Barton, supra note 10 (arguing that to combat short-termism, part of a three-pronged strategy should include "bolstering boards' ability to govern like owners").

14. See Appendix 1-Investment Company Fact Book, ICI 37 (2016), https://www.ici.org/pdf/2016_factbook.pdf [hereinafter ICI 2016 FАСТВОок] (describing mutual fund ownership trends); see also id. at 2 (discussing who holds mutual funds).

15. Mutual funds are the dominant retirement savings vehicle, in part, because of tax incentivized retirement accounts where participation is a part of employees' compensation and there is no viable alternative. Anne M. Tucker, Locked In: The Competitive Disadvantage of Citizen Shareholders, 125 YALE L.J. 163, 168-69 (2015) [hereinafter Tucker, Locked In].

16. See generally JAMES P. HAWLEY \& ANDREW T. Williams, THE Rise OF FiduCiaRy CAPITALISM: How Institutional InVESTORs CAN MAKe CORPORATE AMERICA MORE DEMOCRATIC (2000) (describing the change in corporate ownership and the consequences); see also Ronald J. Gilson \& Jeffrey N. Gordon, The Agency Costs of Agency Capitalism: Activist Investors and the Revaluation of Governance Rights, 113 COLUM. L. REV. 863, 865 (2013) (describing the dominance of institutional shareholders). 
Part II describes how all mutual funds report an indirect measure in their annual N1A filing with the SEC - the portfolio turnover ratio (PTR). ${ }^{17}$ For those unfamiliar with the PTR, it estimates what percentage of a mutual fund's portfolio assets (i.e., stocks) were bought or sold in the last year. The percentage of asset turnover roughly estimates how frequently a mutual fund replaces existing stock holdings with new holdings. For example, a turnover ratio of $20 \%$ can be used as an estimate that a mutual fund buys and sells $20 \%$ of its stock holdings each year, or in other words, holds each stock position, on average, for approximately five years. Critics of short-termism have co-opted the PTR, a measure originally constructed as a transaction cost estimator, as a signal of mutual fund investment time horizons.

The portfolio turnover ratio, as a window into mutual fund time horizons, is criticized as an indirect measure that generates unreliable and inaccurate estimates-critiques explored in Part III. Flawed as the portfolio turnover ratio may be, however, it remains the only estimate that all funds calculate and that all funds report annually to the SEC. Part III catalogues how law, finance, and policy interpret portfolio turnover ratios and link the PTR to mutual fund time horizons.

Four points are clear from the historical review in Part III. First, despite the criticisms levied against the PTR as a time horizon estimator, policy debates and legal scholarship cite to portfolio turnover ratios as evidence - often the only empirical evidence - to support the primary assertion that institutional investors are increasingly short-term and a contagion that infects the time horizons of operating company managers. Second, the empirical basis for short-termism claims is self-referential and dated. It can be traced back to John Bogle's work in the early 2000's. Third, finance literature engages with portfolio turnover ratios, but the work translates poorly to answer the questions of this Article: what do we know about mutual fund time horizons and the strength of the PTR signal? Finally, documenting the widespread use of and reliance on portfolio turnover ratios, and combining it with the absence of new data on the topic, justifies the empirical review undertaken in Part IV.

In Part IV, I chart the portfolio turnover ratios of all open-ended, publically traded mutual funds from 2005-15 to observe trend lines and explore the central question of this Article: are mutual fund investment time horizons increasing or decreasing? ${ }^{18}$ I expand my inquiry by borrowing from finance literature and computing three alternative measures of mutual fund holdings and portfolio turnover-Duration, Churn Rate, and Modified Turnover. ${ }^{19}$ I compare the ten-year trends under each of those measures to the PTR calculations. In these two ways, I test whether portfolio turnover ratios are increasing (more short-termism) and the strength of the PTR signal as to mutual fund investment time horizons. My supporting hypothesis is that the PTR signal is reinforced if the alternative measures are correlated with and tell a time horizon story consistent with that of the PTR. If, on the other hand, portfolio turnover ratio data generate trends inconsistent with the alternative measures and without a correlation, this would discount the signaling value of

17. The U.S. calculation of mutual fund portfolio turnover rates is one of two main approaches, the other being the UCITS methods in the U.K. See infra notes $41-46$ and accompanying text.

18. A ten-year time window is a narrow view and reflects the limits of an empirical project of this nature undertaken in the context of legal scholarship. Future work may expand the inquiry to a broader time range to bolster the observations made herein.

19. I use the Duration measure, the Churn Rate, and the Modified Portfolio Turnover Ratio. Equations, explanations, and results under each measure are set forth in Part V. 
the PTR for mutual fund time horizons. Because the mutual fund industry covers different types of assets and investment strategies that have inherently different time horizons, segmenting out, for example, active versus passive management (index) funds and small versus large cap funds strengthens the test. ${ }^{20}$

This Article contributes to the existing literature by connecting legal scholarship, finance scholarship, industry and policy debates on the issue of mutual fund investment horizons. The data set compiled and analyzed herein contributes to the academic literature by introducing primary, empirical information on mutual fund investment time horizons. ${ }^{21}$ My research fills the empirical gap of the last 15 years on the question of mutual fund turnover ratio trends.

With this empirical evidence, I conclude in Part V. The four measures of mutual fund time horizons, charted over a ten-year period, tell a largely consistent story. Despite significant fluctuation following the 2008 financial crisis, from 2005-2015, mutual funds' investment time horizons did not decrease when evaluated under any measure. This does not undercut the claim that mutual fund time horizons are short; they are consistently shorter than historical figures. Between 2005-2015, the average mutual fund PTR was $79 \%$, which is in sharp contrast to $26 \%$ in 1945 and $45 \%$ in 1975, but lower than estimates from the early 2000 's of $100-110 \% .^{22}$ Recent mutual fund time horizons are not currently in consistent, rapid decline. ${ }^{23} \mathrm{I}$ conclude Part $\mathrm{V}$ with observations about the general strength of the PTR signal, its continued role in mutual fund time horizon analysis and suggestions for future work in the area.

\section{Portfolio Turnover Ratio: U.S. CALCUlation AND USES}

Every open-ended mutual fund calculates and reports its portfolio turnover ratio on its annual $\mathrm{N}-1 \mathrm{~A}^{24}$ filing - the mutual fund prospectus - with the SEC. ${ }^{25}$

20. As described in detail in Part V, mutual funds are sorted by active versus index funds and later by CRSP style and objective codes for large cap, mid cap, small cap and micro-cap, and style funds including growth, growth \& income (blended), and income. See CRSP Style Code, CRSP, www.crsp.com/products/documentation/crsp-style-code (last visited Mar. 6, 2018) (defining the CRSP style and objective code categories).

21. Martijn Cremers and Simone Sepe call for further academic research into the "the behavior of other classes of institutional investors, such as banks, insurance companies, mutual funds, and the like, against the benchmark of aggregate institutional behavior could help further our understanding of the role played by institutional ownership in the corporation's inter-temporal choices." Cremers \& Sepe, supra note 2, at 417.

22. Effects of Short-Term Trading on Long-Term Investments: Hearing on S. 1654 and S. 2160 Before the S. Comm. On Fin, 101st Cong. 58 (1990) (report of the Joint Comm. on Taxation) (citing to Stephen A. Berkowitz and Dennis E. Logue, The Portfolio Turnover Explosion Explored, 13 J. PORTFOLIO MgMT. 38 (1987); see also John Bogle, The Mutual Fund Industry 60 Years Later: For Better or Worse?, Fin. ANALYSTS J. (2005), https://www.vanguard.com/bogle_site/sp20050102.htm (reporting shortening investment time horizons).

23. One commenter working in the mutual fund industry noted that in 2004, the SEC implemented its "Market Timing Rules," effectively eliminating much of the frequent trading that became disruptive to mutual funds and their ability to manage flows. Market-Timing Rule, 17 C.F.R $§ 270.22 c-2$ (2006); Disclosure Regarding Market Timing, 69 Fed. Reg. 22,300 (Apr. 23, 2004) (codified at 17 C.F.R. pts. 239, 274).

24. See SEC Form N-1A, SEC, https://www.sec.gov/about/forms/formn-1a.pdf (last visited Mar. 6, 2018) [hereinafter SEC Form N-1A] (establishing mutual fund annual prospectus reporting requirements).

25. The US calculation of mutual fund portfolio turnover rates is one of two main approaches, the other being the UCITS methods in the U.K. Meaningful Disclosure of Costs and Charges, THE INV. Ass'N (Feb. 2015), https://www.theinvestmentassociation.org/assets/files/consultations/2015/20150210- 
U.S. funds calculate the portfolio turnover ratio by dividing the lesser $^{26}$ of the total purchases or sales of portfolio securities by the monthly average of the value of the fund's portfolio securities (average of the daily net asset value or NAV) ${ }^{27}$ The portfolio turnover ratio excludes all securities transactions with maturity or expiration dates less than one year plus additional exclusions disclosed in the filing. ${ }^{28}$

\section{SEC Portfolio Turnover Ratio Calculation:}

$$
\frac{\text { Lesser of Purchases or Sales }}{\text { Average Fund Value over } 12 \text { months }}
$$

Portfolio turnover ratios provide a window, albeit a fuzzy one, into fund holding patterns. Funds buy and sell securities for many reasons such as (1) to pursue a fund advisor's investment strategy; (2) to buy new assets when new investors invest with the fund; or (3) to sell shares because mutual fund investors redeemed their shares by cashing out of the fund. ${ }^{29}$ Turnover ratios may reflect trading activity motivated by one or more of these reasons. Distinguishing discretionary trades driven by strategy - motivation number 1 - from trades required by fund flows - motivations number 2 and 3 informs how to interpret the portfolio turnover ratio. The motivating context, however, is completely indiscernible when comparing turnover ratios between funds. This limitation, and others, are discussed in Part III.

Funds report portfolio turnover to shed light on transaction costs and fund expenses, which impact fund performance. ${ }^{30}$ The N-1A form describes and interprets the portfolio turnover ratio as follows:

The Fund pays transaction costs, such as commissions, when it buys and sells

iacostsandchargesreport.pdf [hereinafter IA Meaningful Disclosure].

26. An assumption of the SEC portfolio turnover ratio calculation is the amount by which purchases or sales exceed the other does not contribute to turnover. $I d$. at 21 ("[T] he difference between purchases and sales is indicative of the net flow into, or out of, the fund during the year.").

27. A fund's net asset value, or NAV, represents the total assets under management of a fund and the price, per share, paid to an existing investor, or required of a new investor into the fund. See Tucker, Locked In, supra note 15 , at 165 .

28. SEC Form N-1A, supra note 24, at 25. Derivatives are included in the US calculation method, but not in the UCITS method. IA Meaningful Disclosure, supra note 25, at 21; see also infra note 166. The author's discussions with mutual fund executives indicate that TBA and Dollar Rolls are also excluded. Some funds utilize a "TBA" or "dollar roll" strategy, which is typically excluded from the turnover calculation because of the additional noise it creates. Dollar rolls are repurchase transactions in which the one counterparty of a "To Be Announced" trade agrees to sell the TBA in the same month, and then buy it back in a future month. As you can see, a buy, sell, buy trade sequence creates the potential for a large turnover figure, especially when these trades are in the millions or tens of millions of dollars, typically. See, e.g., Dollar Roll Primer, THOMSON ReUTERS (Nov. 14, 2016), http://www.mortgages-tr.com/knowledge-base/2016/11/14/wxifxecc5lfijsvnq7wyj7coc6q7ez.

29. See Tucker, Locked In, supra note 15, at 165 (describing mutual fund flows and unique attributes of share redemption in mutual funds as compared to selling equity shares).

30. Enhanced Disclosure and New Prospectus Delivery Option For Registered Open-End Management Investment Companies, 74 Fed. Reg. 4546, $4554-4557$ (Jan. 26, 2009) (codified at 17 C.F.R. pts. 230, 232, 239, 274); see also Edwin J. Elton et al, Efficiency with Costly Information: A Reinterpretation of Evidence from Managed Portfolios, 6 REV. FIN. STUD. 1, 18 (1993) ("[T]he relationship between performance and turnover becomes negative and significant at the 5 percent level using a two-tailed test. Management does not earn enough excess return to compensate for the full cost of increased turnover."). 
securities (or "turns over" its portfolio). A higher portfolio turnover rate may indicate higher transaction costs and may result in higher taxes when Fund shares are held in a taxable account. These costs, which are not reflected in annual fund operating expenses or in the example, affect the Fund's performance. During the most recent fiscal year, the Fund's portfolio turnover rate was $\%$ of the average value of its portfolio. ${ }^{31}$

Funds report their portfolio turnover ratio in the summary section of Form N-1A for the most recent fiscal year as a percentage of the average value of its portfolio plus a brief description. ${ }^{32}$ Under the 2009 Rules, ${ }^{33}$ funds discuss portfolio turnover ratios in the statement of additional information (SAI), ${ }^{34}$ including factors that may have significantly impacted the portfolio turnover ratio. For example, funds may report that derivative position premiums may increase turnover ${ }^{35}$ and identify other products, like future delivery contracts, that may increase fund turnover. ${ }^{36}$ Funds routinely caution investors that the portfolio turnover ratio may be higher than $100 \%$ annually. ${ }^{37}$

Portfolio turnover ratios also tie into discussions of fund liquidity and dilution-foci of newly enacted SEC rules in 2016-specifically swing pricing. ${ }^{38}$ Keith Cuthbertson describes the fund turnover costs born by long-term mutual fund investors who absorb the price of commissions, bid-ask spreads and price impact costs generated by fund flows from investors leaving or buying into the fund. ${ }^{39}$ These invisible costs of staying in a fund are

31. SEC Form N-1A, supra note 24; see also Am. Funds Emerging Mkts. Bond Fund, Registration $\begin{array}{lllll}\text { Statement } & \text { (Form } & \text { N-1A) } & \text { (Mar. } & 18,\end{array}$ https://www.sec.gov/Archives/edgar/data/1660935/000005193115001502/afembfnla.htm (providing an example of a filed $\mathrm{N}-1 \mathrm{~A}$ )

32. Enhanced Disclosure and New Prospectus Delivery Option For Registered Open-End Management Investment Companies, 74 Fed. Reg. at 4554-4557.

33. Comments on Proposed Rule: Enhanced Disclosure and New Prospectus Delivery Option, SEC, https://www.sec.gov/comments/s7-28-07/s72807.shtml (last visited Mar. 6, 2018) (comments to 2009 final rule on quarterly disclosures; 29 comments reviewed, two discuss portfolio turnover ratio)

34. See SEC Form N-1A, supra note 24 (containing the SAI and instructions).

35. Oppenheimer Emerging Mkts. Innovators Fund, Registration Statement (Form N-1A) (Apr. 2014).

36. "The fund may enter into contracts ... This can increase the fund's market exposure, and the market price of the securities that the fund contracts to repurchase could drop below their purchase price. While the fund can preserve, and generate capital using such contracts by, for example, realizing the difference between the sale price and the future purchase price, the income generated by the fund may be reduced by engaging in such transactions. In addition, these transactions may increase the turnover rate of the fund." American Funds Income Series, Summary Prospectus (Form 487K) (Nov. 1, 2014).

37. See, e.g., Oppenheimer Emerging Mkts. Innovators Fund, Registration Statement (Form N-1A) (Apr. 2014) ("The Fund may engage in active and frequent trading to try to achieve its investment objective and may have a portfolio turnover rate of over $100 \%$ annually. Increased portfolio turnover may result in higher brokerage fees or other transaction costs, which can reduce performance. If the Fund realizes capital gains when it sells investments, it generally must pay those gains to shareholders, increasing its taxable distributions.”). Observations from one mutual fund executive revealed that the SEC staff comments to prospectus disclosures increasingly require "Frequent Trading Risk" to be added to the Principal Risk Section of the Summary Prospectus if the PTR is greater than $100 \%$ for the previous fiscal year. (Notes on file with Author).

38. Investment Company Swing Pricing, 81 Fed. Reg. 82,084 (Nov. 28, 2016) (codified at 17 C.F.R. pts. 210, 270, 274); Investment Company Liquidity Risk Management Programs, 81 Fed. Reg. 82,142 (Nov. 18, 2016) (codified at 17 C.F.R. pts. 270, 274).

39. Keith Cuthbertson et al., Mutual Fund Performance: Measurement and Evidence, 19 Fin. MKTS. INST. \& INSTRUMENTS 63, 149 (2010). 
related to fund flow-motivated transactions and are shouldered by investors that remain in the fund, often retirement investors. ${ }^{40}$

\section{A. UCITS Alternative}

As a point of contrast, the European Commission undertaking for collective investments in transferable securities (UCITS) required an alternative calculation of fund portfolio activity. The measure, discontinued in $2010,{ }^{41}$ added purchase and sales of securities together before subtracting the issues and cancellations. ${ }^{42}$

The UCITS method attempted to identify discretionary trading by separating out fund flows-motivations 2 and 3 - from management strategy trades-motivation $1 .^{43}$ The numerator is divided by the daily average net asset value or daily NAV. ${ }^{44}$ By adding together purchases and sales, the UCITS calculation was prone to bloat. If a fund manager sold all of the securities and bought new in a quarter, the intuitive turnover ratio would be $100 \%$, but under the UCITS it would produce an estimate of $200 \% .^{45}$ For this reason, it is a more accurate estimator of actual transaction costs, but a less accurate estimator of mutual fund investment time horizons. The Investment Association compared the SEC and UCITS methods and recommended a modified SEC approach based upon "operational pragmatism" noting that the methods produced similar results (within $20 \%$ of each other) and were imperfect measures in their own ways. ${ }^{46}$

\section{Portfolio Turnover RATio DATA In PUBlic DEBATES}

The portfolio turnover ratio acts as a mirror reflecting mutual fund investment behavior. The reflected behavior is interpreted to estimate transaction costs ${ }^{47}$ and investment time horizons. ${ }^{48}$ This Part documents the uses of portfolio turnover ratios-as both a cost estimate and, more importantly for this Article, as an estimate of investment time horizon in policy, industry and academia. Each are examined below, and subject to

40. See Tucker, Locked In, supra note 15, at 178-79 (describing the transactional costs born by locked in mutual fund investors, typically retirement investors who entered the securities market through defined contribution plans).

41. Due, in part, to the criticisms levied at both the U.S. and the UCITS method, UCITS excluded turnover ratio disclosures in the 2010 Key Investor Information Document (KIID) Directive 2009/65/EC on UCITS IV and Commission Regulation 583/2010 has replaced the simplified prospectus with the Key Investor Information Document (KIID). IA Meaningful Disclosure, supra note 25, at 18.

42. Id. at 19. The calculation is: (Purchases of Securities+Sale of Securities)-(Subscription of Shares+Redepmption of Shares)

43. $I d$. Average Fund Value over 12 months

44. Id.

45. Id. at 20. On the other side of the coin, the UCITS method can also produce negative turnover ratios, for example, when a fund discontinues selling a share class. Negative portfolio turnover ratios are "widely accepted" as "meaningless." IA Meaningful Disclosure, supra note 25, at 20.

46. $I d$.

47. See id. (discussing transaction costs).

48. For example, the portfolio turnover ratio reflects mutual fund time horizons by generating an approximation of how long, on average, a fund owns each stock. For example, a portfolio turnover ratio of $20 \%$ gives a rough estimate that a fund turns over its holdings once every five years, or in other words, each stock is held for approximately five years. 
signaling and interpretation flaws addressed in Subpart A. Those familiar with portfolio turnover ratios may wish to skip to Subparts B-E where PTR uses are discussed.

Several key points merit noting at the outset. First, historical policy debates and legal scholarship relied heavily upon turnover ratio data as support for the assertion that institutional trading is increasing, and therefore, investment time horizons are decreasing. Second, much of the Congressional testimony and legal scholarship is self-referential, citing to a single source from the early 2000s for the claim of increasing mutual fund short termism. Third, the claim of increasing mutual fund short-termism is contradicted by leading industry estimates from the ICI. Fourth, despite weak foundations, increased mutual fund short-termism claims persist. Fifth, empirical finance studies translate poorly to legal scholarship ${ }^{49}$ because the narrowly-designed empirical studies offer nuanced observations about PTR correlations observable within their datasets that are not fully transferable to policy debates.

\section{A. The Portfolio Turnover Ratio Signal Strength \& Criticisms}

The portfolio turnover ratio is a signal, or proxy, for (1) mutual fund investment time horizons and (2) transaction cost estimators.

To illustrate how portfolio turnover ratios are used, consider two mutual funds. The first fund has approximately $\$ 2.5$ billion in assets and invests in small capitalization technology companies with a growth objective (Small Cap Tech Fund or SCT Fund). ${ }^{50}$ The fund has an annual PTR of 73\%. The second fund has \$1 billion in assets, invests in an income strategy consistent with Islamic principles, and has an annual PTR of 10\% (Islamic Income Fund or II Fund). ${ }^{51}$ For purposes of comparing the SCT Fund to the II Fund, the PRT indicates that the SCT fund changes its portfolio holdings more frequently and therefore likely has a shorter investment time horizon and higher trading transaction costs than the II Fund. The PTR, for reasons discussed below, provides a limited signal beyond these broad-brush strokes because the indirect measure is, at different times, over inclusive, under inclusive, and insensitive. ${ }^{52}$

\section{Time Horizon \& Transaction Cost Estimates}

The portfolio turnover ratio is a blunt measure creating a shadow in relief when used

49. See ICI 2016 FACTBOOK, supra note 14 , at 37

50. This fund example is based loosely on Ridgeworth Capital Silvant Small Stock Growth Fund. See Silvant Small-Cap Growth Stock, VIRTUS INV. PARTNERS, https://www.virtus.com/products/silvant-small-capgrowth-stock\#shareclass.A/period.quarterly (last visited Mar. 6, 2018).

51. This fund example is based loosely on the Amana Income Fund. See SATuRna CAP., http://www.saturna.com/amana/income-fund\#/overview (last visited Mar. 6, 2018). Some of the guiding Islamic principles are the sharing in profits and loss, the prohibition on usury or interest, the prohibition of vice investments such as gambling or pornography, and the prohibition on conventional debt instructions. Id.

52. The analogy of a wearable fitness tracker - a popular device - may be helpful. When the measure is over inclusive, it produces a bloated result distorted on the high end the same as if a fitness tracker recorded $20 \%$ more steps than you actually took each time you moved. When the measure is under-inclusive, it produces a watered down result, painting an incomplete picture the same as if the fitness tracker only recorded $80 \%$ of the steps taken each time you moved. The insensitivity critique is a variation of being over or under inclusive. With insensitivity, the measure is tone deaf - it interprets data without nuance the same as if a fitness tracker recorded all movement, no matter how subtle, as intense cardio exercise. 
as a proxy for fund holding patterns. ${ }^{53}$ Consider if the Islamic Income Fund invests seventy percent of its holdings in ten Fortune 100 companies and holds those assets for seven years on average. The remaining $30 \%$ of II Fund portfolio assets are invested in foreign and smaller capitalization companies and are traded more frequently - a rate of thirty percent. A $30 \%$ turnover ratio for thirty percent of II Fund assets produces a ten percent turnover ratio for the entire fund. Here, the PTR does not produce a clear picture of the fund's investment time horizon-failing to capture accurately either the pool of long-term investments or the pool of shorter-term investments. Similarly, if the II Fund changes its holdings in one of its top ten companies, in that year, it might be tempting to interpret the resulting increase in the PTR (approximately 17\%) as evidence that the fund was shortening its investment time horizon. The reality, of course, is that $93 \%$ of the assets had been traded just as they had been the year before and consistent with the fund's long-term strategy. ${ }^{54}$ Analyzing portfolio turnover without context and without historical data can distort the signal.

Similarly, the PTR signals that between the II and SCT funds, the SCT Fund engages in more transactions and therefore is likely to have higher transaction costs. The strength of the PTR signal is muted by its failure to reflect contributing cost factors, which may help an investor understand how much costlier is the $73 \%$ SCT portfolio turnover compared with the $10 \%$ II Fund turnover. ${ }^{55}$ The SEC has acknowledged these limitations, describing the portfolio turnover ratio as an "imperfect measure" of fund transaction costs. 56

I address the bluntness critique and its several permutations, along with examples below. The key takeaway is that the PTR provides a flat transaction estimate that does not consider liquidity issues, fund strategy, round trip trades, non-equity asset classes, and rare fund events. Each of these critiques are noted below.

53. Because the portfolio turnover ratio can only indirectly capture time horizons, the approach is incapable of coping "with circumstances where substantially all trading activity results from net flows and the pricing mechanism provided protection from dilution." IA Meaningful Disclosure, supra note 25, at 21.

54. Professor Mark Roe provided a good illustration of the portfolio turnover ratio's limitations in extrapolating stock holding patterns in an example of a corporation with 100 shareholders who each own 100 shares for three years. Roe, Corporate Short-Termism, supra note 9, at 999. Thereafter, 10 of the shareholders become active and sell their shares within four months to other active shareholders who sell their stock within four months; 90 shareholders continue to hold for an average of three years.

"One might be tempted then to say that for the ... holders of XYZ stock during the past year the average duration for holding was only twenty months, while in the good old days it was thirty-six months. Holding duration has nearly halved. These statements would be accurate counts, but the question is whether they are the best way to interpret the changing holding duration for policymaking purposes. . . For 90 percent of the shareholders, nothing has changed and their holding period has not shortened." Id.

Turnover ratio's limitations of painting a complete picture at an operating company, apply with equal force to a mutual fund. If a mutual fund churns some, but not all of its portfolio assets, the fund's turnover ratio may paint a fuzzy picture like with operating companies as described by Professor Roe.

55. The SEC noted that "a higher portfolio turnover rate tends to result in higher transaction costs and a lower portfolio turnover rate tends to result in lower transaction costs," but acknowledged the lack of direct correlation between the two. Enhanced Disclosure and New Prospectus Delivery Option For Registered OpenEnd Management Investment Companies, 74 Fed. Reg. 4546, 4554-4557 (Jan. 26, 2009) (codified at 17 C.F.R. pts. 230, 232, 239, 274).

56. $I d$. 


\section{Common Critique: Strategy \& Liquidity}

Mutual fund holdings — what assets are owned — and discretionary trading on a fund's strategy shape portfolio turnover ratios. Fund strategy, fund flow, and asset liquidity critiques highlight how the PTR is an insensitive measure and affect the reliability of the PTR as an estimate of mutual fund time horizon and transaction costs. ${ }^{57}$

Fund portfolio turnover is shaped, in part, by a fund's investment strategy ${ }^{58}$ For example, actively managed funds may have a higher turnover than passively indexed funds. ${ }^{59}$ Small capitalization funds are also expected to have high turnover compared with large cap funds because small cap investing involves less efficient markets, higher volatility in pricing in underlying companies susceptible to news events, attempting growth, and subject to frequent failures. ${ }^{60}$

Similarly consider the different asset types and restrictions between the SCT Funda small cap tech/pharma fund - and II Fund - a growth Islamic fund. The crux of the dominant complaint against the portfolio turnover ratio as a time horizon estimate is that it provides no indication of the motivation prompting the trade. Was the trade forced by investment strategy, or was an investment manager churning and chasing alpha? Because the portfolio turnover ratio can only indirectly signal time horizons, the approach is incapable of digesting turnover drivers by net fund flows and pricing dilution to compare it with strategy-motivated transactions. ${ }^{61}$

Fund flows and liquidity demands influence a fund's portfolio turnover. New investors buying into a fund may require the fund to purchase new assets with the newly invested cash. ${ }^{62}$ Conversely, investors redeeming their shares and exiting may force the fund to sell assets to pay the redemption price to exiting fund shareholders. ${ }^{63}$ Part II first introduced these motivations. A fund's liquidity needs may also be shaped by the demographics of fund subscribers and corresponding liquidity needs: pension funds may be long-term oriented and retail open-ended funds more short-term. ${ }^{64}$ Additionally, unexpected cash flows, either in or out, due to sharp swings in markets may also impact

57. John M.R. Chalmers et al., An Analysis of Mutual Fund Trading Costs 15 (Nov. 23, 1999) (unpublished manuscript), darkwing.uoregon.edu/ finance/FEN_CEK1.pdf.

58. $I d$.

59. See, e.g., Lynn A. Stout, Are Stock Markets Costly Casinos? Disagreement, Market Failure and Securities Regulation, 81 VA. L. REV. 611, 663-64 (1991) (describing active funds as trading more frequently than index funds); see also Craig McCann, Churning, 9 J. LEGAL ECON. 49, 53 (1999) (describing how investment strategy influences portfolio turnover ratio). $C f$. Part $\mathrm{V}$ results where the difference between index and active funds' portfolio turnover ratio is in the distribution and not in the mean.

60. See Guyatt \& Lukomnik, supra note 2, at 42 .

61. The approach is incapable of coping "with circumstances where substantially all trading activity results from net flows and the pricing mechanism provided protection from dilution." IA Meaningful Disclosure, supra note 25 , at 21 .

62. See, e.g., Merced Bullard, The Mutual Fund as a Firm: Frequent Trading, Fund Arbitrage \& The SEC's Response to the Mutual Fund Scandal, 42 Hous. L. REV. 1271, 1317-18 (2006) (“A fund with shareholders who trade frequently would also generally have a high turnover ratio because the constant movement of cash in and out of the fund would require the fund to buy and sell portfolio securities frequently.").

63. Enhanced Disclosure and New Prospectus Delivery Option For Registered Open-End Management Investment Companies, 74 Fed. Reg. 4546, 4554-4557 (Jan. 26, 2009) (codified at 17 C.F.R. pts. 230, 232, 239, 274).

64. See Andrei Shleifer \& Robert W. Vishny, The Limits of Arbitrage, 52 J. FIn. 35 (1997). 
fund liquidity. ${ }^{65}$

An example may illustrate this point. The SCT fund has a strategy to invest in small capitalization pharmaceutical and technology companies, like Spectrum Pharmaceuticals, Inc. Spectrum has a market cap of $\$ 1.9$ billion and almost 250,000 shares outstanding on Nasdaq. ${ }^{66}$ Large volume trades in securities from smaller companies with less liquid securities are more likely to impact the price of the security than with larger companies and more liquid securities. In theory, a deeper pool of stock is less susceptible to supply and demand price impacts. Consider the impact of a 100,000 share sale of Spectrum Pharmaceuticals compared with a 100,000 share sale of Microsoft Corporation - a major holding of II Fund-with over 7.7 billion stock shares outstanding and a market capitalization of $\$ 500$ billion. ${ }^{67}$ Both transactions involve 100,000 shares, but the Spectrum sale likely has a higher price impact than the sale of Microsoft shares.

Asset availability may also impact a stock's price. If II Fund can buy Microsoft shares from several different intermediaries, II may expect a more stable price resulting from the competition. If there is a limited pool of intermediaries selling the Spectrum stock, then the pricing may be more variable and therefore, inefficient. ${ }^{68}$ Variability in stock pricing affects the bid-ask spread, an invisible transaction cost. ${ }^{69}$ Stable pricing minimizes exposure to buying stock more expensively than it can be sold-the basis of bid-ask spreads. Each of our mutual funds-SCT and II-need to acquire 1000 shares of stock. SCT acquires Spectrum Stock and the price varies by $9 \%$ across trades. Compare that with II Fund acquiring 1000 shares of Microsoft stock, which varies by $1 \%$ across trades. ${ }^{70}$ The bid-ask spread exposure is greater for SCT buying Spectrum Stock than for II Fund buying Microsoft, but the 1000 share acquisition for each fund will be treated as the same input in the PTR. In this way, the PTR is blind to how the type of security being bought and sold impacts transaction fees - through bid-ask spreads - perhaps more than the number of units being sold. $^{71}$

65. Enhanced Disclosure and New Prospectus Delivery Option For Registered Open-end Management Investment Companies, 74 Fed. Reg. at 4554-4557; see also Guyatt \& Lukomnik, supra note 2, at 43-44 (attributing the credit crisis of 2008 as a source of increased fund turnover observed in their sample from 20062009).

66. See Spectrum Pharmaceuticals Inc., NASDAQ http://www.nasdaq.com/symbol/sppi (last visited Jan. 27, 2018). The smaller company stock may also be on smaller exchanges with higher transaction costs.

67. See Microsoft Shares Outstanding, https://ycharts.com/companies/MSFT/shares_outstanding (last visited Mar. 6, 2018).

68. Open-End Fund Liquidity Risk Management Programs; Swing Pricing; Re-Opening of Comment Period for Investment Company Reporting Modernization Release, 80 Fed. Reg. 62,274, 62,299 (Oct. 15, 2015) (codified at 17 C.F.R. pt. 270).

69. I describe the bid-ask spread as invisible because it is not directly reflected in the PTR calculation or in other fee and cost estimations provided by mutual funds.

70. For those less comfortable with the stock example, consider gasoline, a highly fungible good with broad availability. The price of retail gasoline may vary by up to 20 cents per gallon within a city. Alternatively consider an antique Rolex watch, which is fungible to some degree, but scarce with limited sellers. The price of the watch may vary more widely from dealer to dealer - say by $\$ 500$ - even within the same city. If you want to buy and sell gas, the stable price minimizes your exposure to buying gas more expensively than you can sell it. If you were buying and selling the Rolex watch, in contrast, the price variation introduces more risk that the watch will not sell at the same price of purchase.

71. '[T]wo conditions that must be met for turnover to fully capture variation in funds' trading costs. First, the average spread of funds' portfolio holdings must be constant across funds and over time. Second, after normalizing against holdings, a fund's volume of trading in a stock must be unrelated to the stock's spread." 
Finally, liquidity may impact smaller funds more significantly than larger funds. Consider how a large cash inflow of \$50M USD may affect a smaller fund-the II Fund at $\$ 1$ billion - with a purchase of $5 \%$ of assets within its strategy within a short time period. If there are limited securities and those are susceptible to significant supply and demand price fluctuations, this type of transaction may be costlier than a $\$ 5$ million inflow at a larger fund - such as SCT at $\$ 2.2$ billion. Here, fund size and liquidity interact. The pool of possible assets to acquire and/or assets that are less susceptible to demand price impacts shape transactions costs. ${ }^{72}$ Smaller net asset (AUM) funds amplify these transaction costs with fewer assets to absorb the costs. For both funds, the inflow may yield a similar number of transactions and thus a similar denominator ${ }^{73}$ for calculating the portfolio turnover ratio. Yet, the smaller funds' trades may be costlier, blunting the sensitivity of the portfolio turnover ratio calculation's inputs.

\section{Common Critique: Round Trip Trades}

The portfolio turnover ratio excludes round trip trades generating an incomplete picture of fund transactions. ${ }^{74}$ Funds calculate the portfolio turnover ratio based on the lesser of purchases or sales ignoring stock that is bought and sold (or vice versa) in the same measurement period. This omission impacts transaction cost estimates significantly as an under inclusive measure. ${ }^{75}$

Excluding round trip trades also distorts the value of the PTR as a time estimate. ${ }^{76}$ Consider if SCT Funds holds Spectrum stock for 2 years and sells at the beginning of 2018. If SCT Fund buys Spectrum stock again in December 30, 2018 neither trade is recorded for PTR calculations. Conversely, if SCT Fund buys Spectrum stock January 2, 2019 one trade is calculated in both the 2018 and 2019 PTR. On the other hand, excluding round trip trades makes the PTR largely insensitive to high frequency trading preventing distortion from extreme outliers. 77

Because all U.S. funds exclude round trips in their turnover ratio calculation, an investor may still be able to infer relative transaction cost exposure and holding patterns between two or more funds. For example, the comparison between SCT's 73\% PTR and II

Chalmers et al., supra note 57, at 20. “[T]urnover will be an accurate proxy for trading costs only if trading costs are proportional to turnover (spread sensitivity close to zero) and the proportionality coefficient (the fund's average spread) is constant across funds .... Both turnover and the average spread of holdings are important determinants of funds' spread costs." Id. at 21.

72. Paul Hanouna et al., Liquidity and Flows of U.S. Mutual Funds, SEC 23 (Sept. 2015), https://www.sec.gov/dera/staff-papers/white. . .liquidity-white-paper-09-2015.pdf.

73. The denominator - the number of transactions - would be the same, or close to the same, between the two funds. The numerator - the total assets - of course, would be different.

74. Mutual Fund Industry Practices and Their Effect on Individual Investors:Hearing Before the Subcomm. On Cap. Mkts., Ins., and Gov't Sponsored Enterprises of the H. Comm. on Fin. Servs., 108th Cong. 203 (2003) (statement of Wayne H. Wagner).

75. A round trip trade does more than double the cost estimate because neither leg was included in the original calculation. Rather it adds two transactions where there was none before.

76. Claudia Champagne et al., Portfolio Turnover Activity and Mutual Fund Performance, $44 \mathrm{~J}$. MANAGERIAL FIN. 326 (2018).

77. See, e.g., K.J. Martijn Cremers \& Ankur Pareek, Short-Term Trading and Stock Return Anomalies: Momentum, Reversal and Share Issuance, 19 REV. FIN. 1649, 1655 (2015) (discussing how quarterly snap shots render a measure insensitive to high frequency trading). 
Fund's 10\% PTR gives the investor a rough comparison between the funds, but is incomplete to estimate anticipated transaction costs or holding periods for either fund.

\section{Common Critique: Asset Classes \& Rare Events}

The portfolio turnover ratio is also a limited estimation of mutual fund transactions because it excludes bonds, derivatives, options, ${ }^{78}$ commodities $^{79}$ and other securities outside of equity markets. ${ }^{80}$ The II Fund's prohibition on debt and usury instruments results in a nearly $100 \%$ equity asset allocation. The SCT fund holds roughly $20 \%$ of its portfolio assets in fixed income instruments like bonds, debentures and quasi-equity. In this way, the 73\% PTR estimated for the SCT fund underestimates the amount of transactions for the fund as a whole because $20 \%$ of the assets - and all of their transactions - are excluded from the turnover estimate. This limitation impacts the PTR signal as to both transaction costs and time horizon estimates as an under inclusive measure.

Additionally, PTR estimates may be skewed by rare events - change in fund manager or investment strategy - rendering the reported ratio a poor indicator of future transaction costs. ${ }^{81}$ Returning to the original example, when the II Fund divests one of its major holdings if, for example the operating company begins participating in a prohibited vice business, the II Fund's PTR would increase. The increased PTR may be indicative of transaction costs, but not of time horizon estimates for the fund outside of special events.

\section{Common Critique: Tax-Specific Concerns}

Portfolio turnover ratios can be a rough proxy for tax efficiency. ${ }^{82}$ Portfolio turnover ratio may help investors interpret a fund's expense ratio, identifying transactions with

78. See, e.g., Donald Arthur Winslow \& Seth C. Anderson, A Model for Determining the Excessive Trading Element in Churning Claims, 68 N.C. L. REv. 327, 331 n.23 (1990) ("Option vehicles present a form of investment that is susceptible to churning (or perhaps a naturally higher rate of turnover that may disguise churning), but not so amenable to traditional measures (including the turnover rate. ..)").

79. See id. ("[c]ommodities differ from other securities in that they are inherently short-term investments, highly sensitive to market fluctuations, and bear commissions computed differently from other securities.").

80. The Impact of Institutional Investors on Corporate Governance, Takeovers, and the Capital Markets: Hearing Before the Subcomm. on Sec. of the S. Comm. on Banking, Housing, and Urban Affairs, 101st Cong. 101-497 (1989) (statement of Carolyn Kay Brancato).

81. Enhanced Disclosure and New Prospectus Delivery Option For Registered Open-End Management Investment Companies, 74 Fed. Reg. 4546, 4554-4557 (Jan. 26, 2009) (codified at 17 C.F.R. pts. 230, 232, 239, 274). Despite these limitations, the SEC declined to incorporate five or ten year portfolio turnover ratio averages into the filing due to calculation complications as well as no "direct correlation between portfolio turnover and transaction costs." Id. See also Letter from Kathleen Clark, Seward \& Kisssel LLP, to Nancy Morris, Sec'y, SEC (Mar. 4, 2008), www.sec.gov/comments/s7-28-07/s72807-124.pdf; Letter from Robert W. Uek, Chair, IDC Governing Council, to Nancy Morris, Sec'y, SEC, (Feb. 15, 2008), www.sec.gov/comments/s7-28-07/s7280751.pdf. Note that in my sample, I exclude all ETF funds, regardless of when classified as such, and similarly treat all funds that identify as index at any point in the sample as an index fund.

82. See, e.g., Tim Beyers, Does Portfolio Turnover Matter?, Motley Fool (Nov. 22, 2006) http://www.fool.com/investing/mutual-funds/2006/11/22/does-portfolio-turnover-matter.aspx (describing the turnover ratio as a rough proxy for tax efficiency and a tool to understand expense ratios). This benefit is overstated because it assumes that a fund is unable to offset the gains with selling positions in losses and neutralizing the taxable event. In this way, portfolio turnover is a positive feature of portfolio management, and does not necessarily correspond to taxable events. Letter from Kathleen Clark to Nancy Morris, supra note 81 . 
potential tax consequences (i.e., capital gains) ${ }^{83}$ There is no direct correlation, however, between turnover ratios and high taxable gains to investors if a fund offsets realized gains with realized losses. ${ }^{84}$ In this way, the turnover ratio may predict bloated tax liability as an over inclusive measure.

The portfolio turnover ratio is not an absolute measure of cost estimates, or, even less so, of time horizons. ${ }^{85}$ Yet, because the portfolio turnover ratio is the only publicly available measure ${ }^{86}$ on mutual fund trading activity, the signal-however flawed-is heavily relied upon. In the next Subparts, I document the relationship between policy and industry interpretations of PTR and its use in law and finance scholarship.

\section{B. PTR Uses}

The SEC requires PTR calculations in all mutual fund annual prospectus filings. The PTR measure, originally intended to inform investors as to transaction costs, ${ }^{87}$ has morphed into a proxy for mutual fund investment time horizons used in academia, policy and industry. This Part documents PTR's role in institutional investors policy and investment initiatives, as well as in a broader public debate on short-termism.

\section{A Literature Review of PTR}

\section{a. PTR in Legal Literature}

Legal scholarship broadly engages with the mutual fund short-termism debate from questions of tax policy, ${ }^{88}$ corporate governance, ${ }^{89}$ market regulation, ${ }^{90}$ to investor

83. "If the Fund realizes capital gains when it sells investments, it generally must pay those gains to shareholders, increasing its taxable distributions." Oppenheimer Emerging Mkts. Innovators Fund, Registration Statement (Form N-1A) (Apr. 2014). See also Reporting Capital Gains, IRS (May 25, 2011) https://www.irs.gov/newsroom/reporting-capital-gains.

84. Increasing Disclosure to Benefit Investors: Hearing on H.R. 887 and H.R. 1089 Before the Subcomm. on Fin. and Hazardous Materials of the H. Comm. on Commerce, 106th Cong. 46 (1999) (statement of the SEC).

85. IA Meaningful Disclosure, supra note 25, at 18 (describing the use of the portfolio turnover ratio by the SEC as "controversial and contested" and describing the turnover ratio as difficult to understand and an imperfect measure). See also Chunhua Lan et al., Mutual Fund Investment Horizon and Performance (2015) (unpublished manuscript), https://www.aeaweb.org/conference/2015/retrieve.php?pdfid=982 (stating that the portfolio turnover ratio "does not describe the rich information that is contained in the heterogeneity of stock holding period").

86. Legal researchers can obtain the portfolio turnover ratio through SEC filings, Morningstar reports and through compilations produced by the ICI. See, e.g., ICI 2016 FACTBOOK, supra note 14, at 37.

87. See SEC Form N-1A, supra note 24 (explaining that a higher portfolio turnover rate may indicate higher transaction costs).

88. See, e.g., Dallas, supra note 5, at 348-51 (discouraging short term trading through tax policy); Lawrence H. Summers \& Victoria P. Summers, When Financial Markets Work Too Well: A Cautious Case for a Securities Transactions Tax, 3 J. Fin. SERV. RES. 261, 263 (1989) (discussing tax policy to reduce transactions, which increased after fix commission fees were removed in 1975).

89. See, e.g., Jesse M. Fried, The Uneasy Case for Favoring Long-Term Shareholders, 124 YALE L.J. 1554, 1577,1626 (2015) ("My analysis indicates that it is ultimately an empirical question as to which shareholdersshort-term or long-term - have interests that are better aligned with a firm's creation of economic value over time."); Bebchuk, supra note 12.

90. Steven L. Schwarcz, Temporal Perspectives: Resolving the Conflict Between Current and Future Investors, 89 MiNN. L. REV. 1044, 1081 (2005) (attributing market efficiency to noise trading and other short- 
protection. ${ }^{91}$ Among legal scholarship, a smaller universe of articles discuss portfolio turnover ratios in the context of the short/long term debate-I count 34 articles between 1990 and 2016. ${ }^{92}$ As observed in other areas, portfolio turnover is discussed both as an indicator of investment time horizons and as an estimate of transaction costs. ${ }^{93}$

\section{b. PTR as Investment Time Horizon Estimate}

A majority of law review articles-21 - cite increasing portfolio turnover rates as evidence of increasing mutual fund short-termism. ${ }^{94}$ Beginning in the late 1990s and gaining momentum after the financial crisis, legal scholarship cites to portfolio turnover ratios as an evidentiary cornerstone in the short-termism debate. ${ }^{95}$ Of these articles, ten provide an estimate of turnover of mutual funds or at the operating company level. ${ }^{96}$ The turnover estimates vary depending upon the time of the article (sample spans over 25 years) and the context (operating company or mutual fund, active fund vs. hedge fund). The most frequently occurring estimates in legal literature suggest that NYSE stocks are held, on average, less than one year, and that managed (active) mutual funds have an average turnover ratio of $75-115 \% .{ }^{97}$ New scholarship by Martijn Cremers and Simon Sepe finds

term trading practices); Paul G. Mahoney, Is There a Cure for "Excessive" Trading?, 81 VA. L. REv. 713, 71819 (1995) (describing noise trading and short-term trading and consequences).

91. Dallas, supra note 5, at 336 (discussing investor protections in the Dodd-Frank Act); see also Leo E. Strine, Jr., Can We Do Better by Ordinary Investors? A Pragmatic Reaction to the Dueling Ideological Mythologists of Corporate Law, 114 ColuM. L. REV. 449, 502 (2014) [herineafter Strine Jr., Can We Do Better?] (discussing limited protections in shareholder democracy for indirect investors).

92. I identified 34 articles that specifically discuss portfolio turnover.

93. Dallas, supra note 5, at 297 (discussing declining average holding periods of stock by institutional investors); Id. at 320-30 (discussing operating expense ratio and the exclusion of brokerage commissions-fees impacted by portfolio turnover).

94. See Appendix 2, for the table of coded articles; additional legal research analysis on file with author. $C f$, Cremers \& Sepe, supra note 2, at 403-04 (reporting lengthening institutional investor time horizons over 1983-2015).

95. See, e.g., Appendix 2; additional legal research analysis on file with author.

96. Iris H-Y Chiu, Reviving Shareholder Stewardship: Critically Examining the Impact of Corporate Transparency Reforms in the UK, 38 DEL. J. CORP. L. 983, 1013 (2014); Dent Jr., supra note 8, at 122 n.103; Alicia Davis Evans, A Requiem for the Retail Investor?, 95 VA. L. REV. 1105, 1107, 1124 (2009); Nadelle Grossman, Turning a Short-Term Fling Into a Long-Term Commitment: Board Duties in a New Era, 43 U. MiCH. J.L. REFORM 905, 910 (2010); David Millon, Shareholder Social Responsibility, 36 SEATTLE U. L. REV. 911, 913 (2013); Lawrence E. Mitchell, A Critical Look at Corporate Governance, 45 VAND. L. REV. 1263, 1291 n. 119 (1992); Roe, Corporate Short-Termism, supra note 9, at 1000; P. Alexander Quimby, Note, Addressing Corporate Short-Termism through Loyalty Shares, 40 FLA. ST. U. L. REV. 389, 394-95 (2013); Stout, supra note 59, at 66364; Leo E. Strine, Jr., One Fundamental Corporate Governance Question We Face: Can Corporations be Managed for the Long Term Unless Their Powerful Electorates Also Act and Think Long Term?, 66 Bus. LAW. 1, 10-11 (2010) [hereinafter Strine Jr., One Fundamental Corporate Governance Question]; Justice Jack B. Jacobs, "Patient Capital": Can Delaware Corporate Law Help Revive It?, 68 WASH. \& LEE L. REv. 1645, 165051 (2011).

97. Chiu, supra note 96, at 1013 (stating that "empirical research reports that most institutions turn over their portfolios by 72 to 200 percent every year"); Dent Jr., supra note 8, at $122 \mathrm{n} .103$ (stating that "mutual funds had a median portfolio turnover rate of 0.72 , meaning that they held their investments somewhat more than a year on average"); Evans, supra note 96, at 1124 (citing to a $91 \%$ turnover rate by 2005); Grossman, supra note 96, at 910 (estimating that "every share of stock of a NYSE-listed company was traded at least once during the year"); Quimby, supra note 96, at 394-95 (stating that "[m]utual funds-which are the primary 401(k) contribution investors for Americans-turn over $117 \%$ of their stock portfolio a year, while hedge funds turn over $300 \%$ 
a relationship between active institutional investor ownership and increased activism with decreased investment time horizons, proving an empirical basis for claims that institutional investor time horizons can infect and influence corporate strategies. ${ }^{98}$

Professors Lucian Bebchuk and Mark Roe cite alternative empirical work to support the opposite assertion that turnover ratios are decreasing, thus holding patterns among mutual fund investors are increasing. ${ }^{99}$ Their work casts doubt on the "widely held" but "unquestioned" view that short-term trading among institutional investors has increased dramatically to negative consequences. ${ }^{100}$ Subsequent law review articles-those published after 2013 - have not widely adopted this view. ${ }^{101}$

\section{c. PTR as a Transaction Cost Estimate}

Legal literature also discusses portfolio turnover ratios in the context of cost estimates and the relationship between fees and returns to investors. Scholars note the relationship between turnover and transaction fees born of commissions, bid-ask spreads, marketimpact costs and opportunity costs. ${ }^{102}$ Others link high turnover to high transactions

annually"); Stout, supra note 59, at 663-64 (stating that "the average active stock mutual fund turns over more than seventy-five percent of its portfolio annually"); Strine Jr., One Fundamental Corporate Governance Question, supra note 96, at 10-11 ("The average portfolio turnover at actively managed mutual funds, for example, is approximately 100 percent a year. Median turnover is in the 65 percent range."); Jacobs, supra note 96, at 1650-51 (stating that "[a]t actively managed mutual funds, which constitute the primary investor of American 401(k) retirement funds, the annual turnover is about 100\%").

98. Cremers \& Sepe, supra note 2, at 390, 413.

99. Bebchuk, supra note 12, at 1661 (" $[R]$ ecent empirical work suggests that the holding duration of institutional investors has been stable over the past quarter of a century and, if anything, lengthened slightly over time. And it is far from clear that activist investors have shorter investment horizons than other shareholders."); Roe, Corporate Short-Termism, supra note 9, at 1000 ("A team of finance economists-Martijn Cremers, Ankur Pareek, and Zacharias Sautner - recently assembled data showing that two of America's primary shareholdersFidelity and Vanguard - have holding durations that have not budged since 1985. The overall holding duration for mutual funds and pension funds-America's core stockholder class-increased during the quarter century from 1985 to $2010 . "$ ).

100. Roe, Corporate Short-Termism, supra note 9, at 1006. See also Lucian A. Bebchuk et al., The LongTerm Effects of Hedge Fund Activism, 115 Colum. L. REv. 1085, 1096 (2015) ("[I]t is theoretically possible that activists might, in some cases, want companies to act in ways that are not value-maximizing in the long term. However, it is far from clear how often such cases arise. Furthermore, such cases might be outweighed by cases in which activists have a clear interest"); Bebchuk, supra note 12, at 1661 ("There are reasons to believe that insulation advocates overestimate the extent to which activist interests, and shareholders in general, have short horizons."); Dent Jr., supra note 8, at 126-28 (2010) ("In sum, the charge that activist investors try to cut corporate R \& D seems meretricious.").

101. See e.g., Lynne L. Dallas \& Jordan M. Barry, Long-Term Shareholders and Time-Phased Voting, 40 DEL. J. CORP. L. 541, 564 (2016) (noting a "continuing trend toward short-term shareholding over several decades"); Strine Jr., Can We Do Better?, supra note 91, at 478 ("Actively traded funds turn over at a rate which makes it difficult to believe that their managers are basing their decisions on a genuine assessment of the corporations' long-term cash flow prospects as opposed to their speculation abaout where the market is heading."); Marc T. Moore, \& Edward Walker-Arnott, A Fresh Look at Stock Market Short-Termism, 41 J. L. \& SoC'Y. 416, 418 (2014) (identifying short-termism as problematic). Cf, Coffee Jr. \& Palia, supra note 1, at 41 (describing shrinking investment time horizon evidence as "far from dispositive"); $i d$. at 39 (describing the term short-termism as "an illegitimate argument, at best a 'debater's weapon' used only by corporate lobbyists"); Cremers \& Sepe, supra note 2 (reporting lengthening institutional investor time horizons over 1983-2015).

102. See, e.g., Winslow \& Anderson, supra note 78, at 343 ("Because transaction costs (commissions) are a direct cost to the investor and are a function of turnover, they directly affect the return that a portfolio will 
costs - fees that reduce the returns enjoyed by mutual fund investors. ${ }^{103}$ Early portfolio turnover articles - those written before the 2008 financial crisis-focus on turnover as estimators of costs, but not those written afterwards. ${ }^{104}$

\section{d. Limitations of Portfolio Turnover Ratio Calculations}

Only two law review articles specifically discuss the limitations of turnover ratios as an accurate cost estimator; none raise the limitations of the turnover ratio to reflect investment horizons. ${ }^{105}$ Considering the criticisms levied against portfolio turnover ratios as cost and time horizon estimates summarized Part A, this oversight perhaps suggests failure to appreciate the nuance of PTR calculations or, alternatively, that a deeper understanding of the calculation has evolved over time. ${ }^{106}$

\section{e. Law \& Policy}

The policy documents and legal scholarship self-referentially cited to common academic sources for the assertion of decreasing time horizons and increasing shorttermism. Many of the sources attributed the claim to 2003 testimony from John Bogle. ${ }^{107}$ The absence of new data in legal scholarship demonstrates the need to ascertain current investment time horizon trends. My research fills this gap.

\section{PTR in Finance Literature}

Finance and related business scholarship incorporates portfolio turnover measures into a variety of academic, empirical studies. The universe of scholarship engaging with institutional investor turnover or short-termism - at the fund or operating company levelis large. I reviewed 33 articles at the intersection of these two inquiries. In contrast to the legal scholarship review, few finance articles relied heavily on portfolio turnover for the assertion that investment time horizons are increasingly short-term. ${ }^{108}$ The following

generate. Any transaction costs that are in excess of the minimum amount necessary to maintain a portfolio at a given point on the efficient frontier will reduce the investor's return, yet will not reduce the risk involved.").

103. Stout, supra note 59, at 674-75 (noting the impact of trading costs on return, especially when compounding and opportunity costs are taken into account). See also Winslow \& Anderson, supra note 78, at 329 ("The symptoms of this lack of financial grounding have been imprecision and timidity in use of quantitative turnover rates as a factor indicative of excessive trading."); Bullard, supra note 62, at 1318 (stating that high portfolio transaction costs may effect turnover rate); Dallas, supra note 5, at 329-30 (stating the importance of taking "trading costs into account").

104. See, e.g., Dallas, supra note 5, at 296-301 (discussing asset turnover, estimated time horizons, and corporate governance effects).

105. Winslow \& Anderson, supra note 78, at 340 ("[T]he sweeping generality of these tests ignores differences between the objectives of investors, a factor clearly relevant in assessing churning claims, because the excessiveness of a given turnover rate depends on those objectives and the nature of the account."); Bullard, supra note 62 , at $1317-18$.

106. Anne M. Tucker, The Citizen Shareholder: Modernizing the Agency Paradigm to Reflect How and why a Majority of Americans Invest in the Market, 35 SEATTLE U.L. REV. 1299, 1326 n. 133 (2012) (citing to other scholars' work and Morningstar reported mutual fund portfolio turnover ratios in connection with claims of shortterm mutual fund investment horizons).

107. See infra notes 125,130 .

108. See, e.g., Brian Bushee, Do Institutional Investors Prefer Near-Term Earnings Over Long-Run Value?, 18 CONTEMP. ACCT. RES. 207, 213-15 (2001) [hereinafter Bushee, Do Institutional Investors] (categorizing 
discussion summarizes the more nuanced and limited ways in which finance literature interprets and incorporates PTR.

Fund portfolio turnover is used as a proxy in finance literature ${ }^{109}$ for behavioral concepts like investor under reaction, ${ }^{110}$ liquidity, ${ }^{111}$ disagreement, ${ }^{112}$ and information integration into market pricing. ${ }^{113}$ Turnover may also be used to identify discrete categories of investors such as hedge funds ${ }^{114}$ and high frequency traders ${ }^{115}$ and to interpret their role in financial markets.

Other finance scholars have interpreted turnover as a measure of investor attention ${ }^{116}$ or to signal short investment horizons linked to myopic firm pricing, overweighting shortterm earnings ${ }^{117}$ and underweighting long-term earnings potentials. ${ }^{118}$ High portfolio turnover ratios of institutional investors has been linked to reduced corporate research and development $(\mathrm{R} \& D)$ spending and innovation. ${ }^{119}$

Still others have linked short investor time horizons to both the likelihood that a firm will receive an acquisition bid and for a lower bid premium, tying investor time horizons into a larger literature on the impact of shareholder identities and stock price. ${ }^{120}$ Investor time horizons are linked to larger discussion about the scarcity of long-term capital due to

institutional investors as long or short term, based in part upon their turnover ratios as well as their organizational status such as endowment or hedge funds); see also Chunhua Lan et al., supra note 85, at 6 (noting difficulty in interpreting turnover data and the cross-sectional variation in investment horizons of institutional investors).

109. See generally Cremers \& Pareek, supra note 77, at 1654-55.

110. C. Lee \& B. Swaminathan, Price Momentum and Trading Volume, 55 J. Fin. 2017, 2018 (2000).

111. Y. Amihud, Illiquidity and Stock Returns: Cross-section and Time-Series Effects, 5 J. FIN. MKTs. 31, 35 (2002).

112. H. Hong \& J.C. Stein, Disagreement and the Stock Market, 21 J. ECON. PERSP. 109, 124-25 (2007).

113. T. Chordia \& B. Swaminathan, Trading Volume and Cross-Autocorrelation in Stock Returns, 55 J. FIN. 913, 915 (2000).

114. Alon Brav et al., Hedge Fund Activism, Corporate Governance, and Firm Performance, 63 J. Fin. 1729, 1732 (2008).

115. Nan Qin \& Vijay Singal, Mutual Fund Performance in the Era of High Frequency Trading, 3, 7 (2017) (unpublished manuscript), https://papers.ssrn.com/sol3/papers.cfm?abstract_Id=2726427; see also DAVIS ET AL., supra note 1, at 52 (estimating computer generated high-frequency trading to comprise over $60 \%$ of stock market trades).

116. K. Hou et al., A Tale of Two Anomalies: The Implication of Investor Attention for Price and Earnings Momentum (The Ohio State University, Working Paper, 2009).

117. See, K.J. Martijn Cremers \& Jianping Mei, Turning Over Turnover, 20 REv. Fin. STUD. 1749, 1750 (2007) (describing the effect of turnover at individual stock levels). See also Brian Bushee, Institutional Investors, Long-Term Investment, and Earnings Management (Jan. 1998) (unpublished manuscript), https://papers.ssrn.com/sol3/papers.cfm?abstract_id=52686; Andrew G. Haldane, Exec. Dir., Fin. Stability \& Richard Davies, Economist, Fin. Inst. Div., Bank of Eng., Speech at the 29th Societe Universitaire Europeene de Recherches Financieres Colloquium in Brussels: The Short Long (May 11, 2011), https://www.bis.org/review/r110511e.pdf (describing statistically significant evidence of short-termism in the pricing of companies' equities).

118. Bushee, Do Institutional Investors, supra note 108, at 238.

119. Brian J. Bushee, The Influence of Institutional Investors on Myopic R\&D Investment Behavior, 73 ACCT. REV. 305, 330 (1998) (finding that "a high proportion of ownership by institutions exhibiting transient ownership characteristics (i.e., high portfolio turnover diversification, and momentum trading) significantly increases the probability that managers reduce $\mathrm{R} \& \mathrm{D}$ to boost earnings.").

120. Jose-Miguel Gaspar et al., Shareholder Investment Horizons and the Market for Corporate Control, 76 J. FIN. ECON. 135, 136-38 (2005); see also E.S. Hotchkiss \& D. Strickland, Does Shareholder Composition Matter? Evidence from the Market Reaction to Corporate Earnings Announcements, 58 J. FIN 1469, 1472 (2003). 
liquidity needs and distorted incentives of delegated portfolio management. ${ }^{121}$

Finance scholarship also uses mutual fund portfolio turnover as an indicator of fund operational expenses, frequently comparing and correlating turnover with fund performance and investors' returns. ${ }^{122}$ Generally, higher turnover and expenses correlate negatively with fund performance. ${ }^{123}$ Because fund turnover is an indicator of, not a true measure of, transaction costs ${ }^{124}$ subsequent research studies generated a more direct measure - an estimate of trading costs based upon commissions, spreads, and price impact rather than rely on the indirect measure of turnover-with fund performance. ${ }^{125}$

Because portfolio turnover data is incorporated into finance literature's narrowlydesigned empirical studies and is used to make nuanced observations about correlations observable within their datasets, these findings translate poorly to the main question of this Article, and can't be used as such. In much of the finance literature, portfolio turnover ratios are just one data point in a sophisticated empirical design, or used as part of a robustness check on the primary empirical claim. These limitations pose translation issues when legal scholars look to finance work that included time horizon metrics, but which are not independently establishing mutual fund time horizons.

\section{PTR in U.S. Policy \& Business Debates}

\section{a. U.S. Legislation \& Policy}

Several legislative initiatives focused directly or indirectly on institutional investors ${ }^{, 126}$ portfolio turnover rates spanning from 1986 to 2010 and produced 10 congressional hearing records; five from the Senate and five from the House of

121. "Shorter horizons could result from the inability to continuously gather capital to implement long-term strategies or from the incentives to trade on short-term signals if there is imperfect information about the portfolio manager's ability." Gaspar et al., supra note 120, at 136.

122. See, e.g., Roger Edelen et al., Shedding Light on "Invisible" Costs: Trading Costs and Mutual Fund Performance, 69 Fin. ANALYSTS J. 33, 35 (2007) (describing direct estimates of fund trading costs as difficult because of availability and computational complexity but noting that turnover was widely used by academics and financial managers because of its availability); see also Keith Cuthbertson et al., Mutual Fund Performance: Measure and Evidence, 19 FIN. MKTS. INST. \& INSTRUMENTS 63, 97 (2010) (describing finance literature research on mutual funds as being concerned with two key issues of abnormal performance. The first is, ex-post performance that outperforms similar funds and is persistent to support the idea that managers add value. The second is ex ante abnormal return identification.).

123. Edwin J. Elton et al., Efficiency with Costly Information: A Reinterpretation of Evidence from Managed Portfolios, 6 REV. FIN. STUD. 1, 18 ("[T] he relationship between performance and turnover becomes negative and significant at the 5 percent level using a two-tailed test. Management does not earn enough excess return to compensate for the full cost of increased turnover.").

124. Chalmers et al., supra note 57 , at 1 .

125. Cuthbertson et al., supra note 122, at 155 (describing turnover as an indirect measure and citing subsequent literature observing a cost estimator in conjunction with fund performance).

126. Pension funds were the original focus of the legislative inquiry, and after the rise of the defined contribution society and mutual fund investment increase, the conversation turned from pension funds as institutional investors to mutual funds. See, e.g., Pension Funds in the Capital Markets: Hearing Before the Subcomm. on Telecomm, Consumer Prot., and Fin. of the H. Comm. on Energy and Commerce, 99th Cong. (1986); Mutual Fund Industry Practices and Their Effect on Individual Investors: House Hearing Before the Subcomm. on Capital, Mkt. Ins. and Gov't Sponsored Enter. Of the H. Comm. on Fin. Serv., 108th Cong. (2003) [hereinafter Mutual Fund Industry Practices, 108th Cong.]. See also Anne M. Tucker, Retirement Revolution: Unmitigated Risks in the Defined Contribution Society, 51 Hous. L.REv. 153, 156-58 (2013). 
Representatives. The Congressional records, totaling over 2600 pages, contain over $70^{127}$ oral testimonies, committee discussions, written testimony submissions, letters to a Congressional committee, and attached reports that directly discussed institutional investors' portfolio turnover ratio and grappled with, to varying degrees, the value and correct interpretation of portfolio turnover ratios. The Congressional record documents the power of the short-term narrative with repeated testimonies emphasizing the threat of everincreasing short-termism. Thirty record entries discussed the threshold question of whether institutional investors are increasingly short-term, all concluded or inferred that they are. Senator and Chairman Lloyd Bentsen opened a Senate hearing before the Committee on Finance on the Effects of Short-Term Trading on Long-Term Investments ${ }^{128}$ by stating:

Heads of large corporations have been telling me that there is a real deterrent these days to making long-term investments ... Institutional investors react to short-term fluctuations by churning their stock holdings . . . In 1970, the turnover rate was 19 percent, now it is over 50 percent ... I am concerned that too many investors today, particularly institutional investors, look just to the quarterly returns, instead of the long-term prospects of the companies ... [I] would like for this hearing to address the following questions: Has there been a marked trend toward short-term trading behavior? If so, what are the effects of that trend on the business decisions of our country's corporate leaders?

Thirty-seven entries cited portfolio turnover ratios as evidence of institutional investors' shortened time horizons. ${ }^{129}$ Fourteen entries focused on whether portfolio turnover ratios are good estimators of transaction costs, ${ }^{130}$ specifically addressing tax implications. ${ }^{131}$ Entries frequently linked portfolio turnover ratios to a broader debate about the impact of fees on returns to mutual and pension fund investors. ${ }^{132}$ Fourteen entries linked high turnover with high fees - commissions, opportunity costs, market spread and tax-linking both to poor performance because high fees negatively impact investors'

127. This number is a rough estimate of substantive discussions of portfolio turnover ratio and includes repeated entries by the same individual who may have appeared for oral testimony and questioning as well as submitted a written response. See, e.g., Effects of Short-Term Trading on Long-Term Investments: Hearing on S. 1654 and S.2160 Before the S. Comm. on Fin., 101st Cong. (1990) (statement of Sen. Bob Dole) [hereinafter Effects of Short-Term Trading, 101st Cong.]. It may also include an individual who testified before several committees as such John C. Bogle did in 2003. Mutual Fund Industry Practices, 108th Cong., supra note 126; Review of Current Investigations and Regulatory Actions Regarding the Mutual Fund Industry: Hearings before the Comm. on Banking, Hous. and Urban Affairs US Senate,108th Cong. (2003).

128. Effects of Short-Term Trading, 101st Cong., supra note 127.

129. See, e.g., The Mutual Funds Integrity and Fee Transparency Act of 2003: Hearing Before the Subcomm. on Capital Mkt., Ins. and Gov't Sponsored Enter. of the H. Comm. on Fin. Serv., 108th Cong. 102 (2003) (statement of David S. Pottuck, CEO of the Charles Schwab Corporation).

130. "The advantage that turnover rate (an indirect indicator of fund transaction costs) has over the dollar amount of brokerage costs (a more direct measure) is that turnover rate is less affected by the asset size of a fund. Unfortunately, disclosure of a fund's portfolio turnover does not directly reveal a fund's actual transaction costs or elicit specific information about these costs. A mutual fund's transaction costs include commissions, spreads, market impact costs and opportunity costs." Mutual Fund Trading Practices and Abuses that Harm Investors; Hearing before the Fin. Mgmt., the Budget and Int'l Sec. Subcomm. of the S. Comm. on Gov't Affairs, 108th Cong. 225 (2002) (statement of Paul F. Roye, Director of Division of Investment Management, SEC).

131. See supra notes 83-84 and accompanying text.

132. See infra Appendix 1. 
return. $^{133}$

Closely related to the issue of fee estimates and fee impact, twenty-one entries advocated for the continued or enhanced disclosure of the portfolio turnover ratio to educate investors and shine light on outlier fund behavior. ${ }^{134}$ Proposed House bill 1089 the Mutual Fund Tax Awareness Act of $2000^{135}$ _illustrates the relationship between these concerns. The text of the bill begins,

The Congress finds the following:

$\ldots$

(2) The average portfolio turnover rate for an actively managed (nonindex) fund has increased from 30 percent 20 years ago to almost 90 percent today, and average capital gains distributions of growth funds, per share, have more than doubled in the last 10 years.

(3) If a fund's performance is based mostly on short-term gains, investors can lose a significant part of their return to taxes.

.

(6) Improved disclosure of the effect of taxes on mutual fund performance would allow shareholders to compare after-tax returns to raw performance, and would permit the investors to determine whether the fund manager tries to minimize tax consequences for shareholders.

(7) ... the prospectus may not expressly inform shareholders about the impact the portfolio turnover rate has on total returns.

Seventeen entries noted the limitations of the portfolio turnover ratio calculations. ${ }^{136}$ Twelve entries focused exclusively on the portfolio turnover ratios of pension funds without discussing mutual funds generally. ${ }^{137}$

The legislative record demonstrates that policy makers and testifying experts cited to portfolio turnover ratios as evidence of investor short-termism, often to support legislative measures such as taxes, disclosures and enhanced mutual fund oversight.

133. See, e.g., Mutual Fund Industry Practices, 108th Cong., supra note 126 (statement of John C. Bogle, Vanguard Group and Bogle Financial Markets Research Center).

134. See infra Appendix 2.

135. Mutual Funds Tax Awareness Act of 2000, H.R. 1089, 106 ${ }^{\text {th }}$ Cong. (1999-2000) (H.R. 1089 passed the House and was read in Committee in the Senate, but did not pass). For additional Legislature history, see Billover, CONGRESS.GOV, https://www.congress.gov/bill/106th-congress/house-bill/1089/actions (last visited Mar. 11, 2018).

136. See infra Appendices 1 \& 2; additional legal research and Congressional record analysis on file with author.

137. See infra Appendices $1 \& 2$; additional legal research and Congressional record analysis on file with author. 
Table 1: Congressional Record Entries

\begin{tabular}{|l|l|}
\hline Short-termism debate generally & 30 \\
\hline Portfolio turnover ratio as evidence of short-term & 37 \\
\hline Disclosure of portfolio turnover ratio & 21 \\
\hline Portfolio turnover ratio as a transaction cost estimate & 14 \\
\hline Portfolio turnover ratio \& fee impact on returns & 14 \\
\hline Criticisms of portfolio turnover ratio calculations & 17 \\
\hline General portfolio turnover ratio discussion & 17 \\
\hline Positive/ favorable discussion & 15 \\
\hline Pension specific testimony & 12 \\
\hline
\end{tabular}

\section{b. Business \& Industry Reports}

The business community discusses portfolio turnover ratios and mutual fund investment time horizons in two different ways. Business thought leaders and think tanks, such as Dominic Barton of McKinsey \& Co, ${ }^{138}$ Andrew G. Haldane, ${ }^{139}$ Chief Economist at the Bank of England, and The Aspen Institute ${ }^{140}$ engage directly with the question of increasing short-termism. These industry specialists discuss short-termism, often in reference to mutual funds' increasing turnover rates and shrinking investment time horizons. ${ }^{141}$ For example, building on these themes, a 2010 study of institutional asset managers' investment time horizons found that $65 \%$ of asset managers exceeded their expected portfolio turnover on average by $26 \%{ }^{142}$ In other words asset managers - those who direct mutual fund and other institutional investments - trade more than they say and think they do, creating a time horizon conflict between fund managers and clients. ${ }^{143}$

The Investment Company Institute (ICI), on the other hand, reports recent data describing decreasing turnover ratios, suggesting increasing investment time periods. The

138. Barton, supra note 10; see also Bailey \& Godsall, supra note 8, at 3, 7 (noting that institutional investors played a role in shaping short term pressures on corporate board members, but also noting that the biggest source of pressure was the board itself).

139. Haldane, supra note 117 (describing short-termism debate and empirical evidence supporting the dual assertions that short termism is on the rise and is correlated with negative externalities).

140. Overcoming Short-Termism: A Call for a More Responsible Approach to Investment and Business $\begin{array}{llllll}\text { Management, } & \text { ASPEN } & \text { INST. } & 3 & \text { (Sept. } & 9,\end{array}$ https://assets.aspeninstitute.org/content/uploads/files/content/docs/pubs/overcome_short_state0909_0.pdf ("focus of some short-term investors on quarterly earnings and other short-term metrics can harm the interests of shareholders seeking long-term growth and sustainable earnings"); see also Long-Term Value Creation: Guiding Principles for Corporations and Investors, ASPEN INST. (June 15, 2010), https://assets.aspeninstitute.org/content/uploads/2016/04/Aspen_Principles_with_signers_June_10_0.pdf (establishing aspirational guidelines for good business practice).

141. See supra note 140 (noting the high rates of portfolio turnovers).

142. Guyatt \& Lukomnik, supra note 2, at 41.

143. Id. at 44 . 
ICI, an association of regulated funds established in 1940, collects and distributes data from its member funds and annually produces the ICI Factbook. ${ }^{144}$ The ICI-a leading source of mutual fund data for industry, businesses and academics ${ }^{145}$ _reports a generally positive outlook on mutual fund portfolio turnover trends as declining. The ICI reported between 2012 and 2016 that the asset-weighted turnover rates were below the national average over the past 30-40 years. ${ }^{146}$ According to ICI, the average asset-weighted turnover rate for mutual funds between 1908 and 2015 was $60 \%{ }^{147}$

The ICI reports the asset-weighted rate ${ }^{148}$ because by giving more weight to funds with larger assets, the weighted PTR mean "indicates the average portfolio turnover actually experienced by fund shareholders." ${ }^{\prime 49}$ The asset weight includes both active and index funds and the turnover ratio are pulled from the fund's annual prospectus filings (the form N1-A). ${ }^{150}$

144. About ICI, ICI, https://www.ici.org/about_ici/mission (last visited Feb. 19, 2018); ICI 2016 FACTBOOK, supra note 14.

145. For example, a recent Westlaw search by the author produced 3,265 law review articles and journals citing to the ICI publications. Per the 2016 Annual Report, the ICI represents more than 17,000 funds. ICI 2016 FАСТВОOK, supra note 14. For a list of member funds belonging to the ICI, see Membership, ICI, https://www.ici.org/about_ici/membership (last visited Mar. 11, 2018).

146. ICI 2016 FАСТВOOK, supra note 14, at 37 ("In 2015, the asset-weighted annual turnover rate experienced by equity fund investors was 44 percent, well below the average of the past 36 years."); 2015 Investment Company Fact Book, ICI 37 (2015), https://www.ici.org/pdf/2015_factbook.pdf ("In 2014, the assetweighted annual turnover rate experienced by equity fund investors was 43 percent, well below the average of the past 35 years."); 2014 Investment Company Fact Book, ICI 36 (2014), https://www.ici.org/pdf/2014_factbook.pdf ("In 2013, the asset-weighted annual turnover rate experienced by equity fund investors was 41 percent, well below the average of the past 34 years."); 2013 Investment Company Fact Book, ICI 29 (2013), https://www.ici.org/pdf/2013_factbook.pdf ("In 2012, the asset-weighted annual turnover rate experienced by equity fund investors was 48 percent, well below the average of the past 33 years (Figure 2.5)."); 2012 Investment Company Fact Book, ICI 31 (2012), https://www.ici.org/pdf/2012_factbook.pdf ("In 2011, the asset-weighted annual turnover rate experienced by equity fund investors was 52 percent, somewhat below the average experience of the past 38 years (Figure 2.7).”).

147. ICI 2016 FАСТВOOK, supra note 14 , at 37.

148. To generate an asset-weighted average, a weight must be calculated for each fund, which is a fund's assets divided by the total assets of all funds in a category (i.e., all equity funds). Multiplying each fund's turnover ratio by the weight generates the asset-weighted average. Neither the calculation nor the underlying data for the ICI calculations are made available, as are other types of figures reported by the ICI. Helpful staff at the ICI responded to my inquiries and provided the information. Email from Emily Gallagher, ICI, to author (March 18, 2016) (on file with author).

149. ICI 2016 FАСТВOOK, supra note 14, at 37 ("Neither a simple average nor a median takes into account where fund assets are concentrated.").

150. Id. 
Figure $1^{151}$

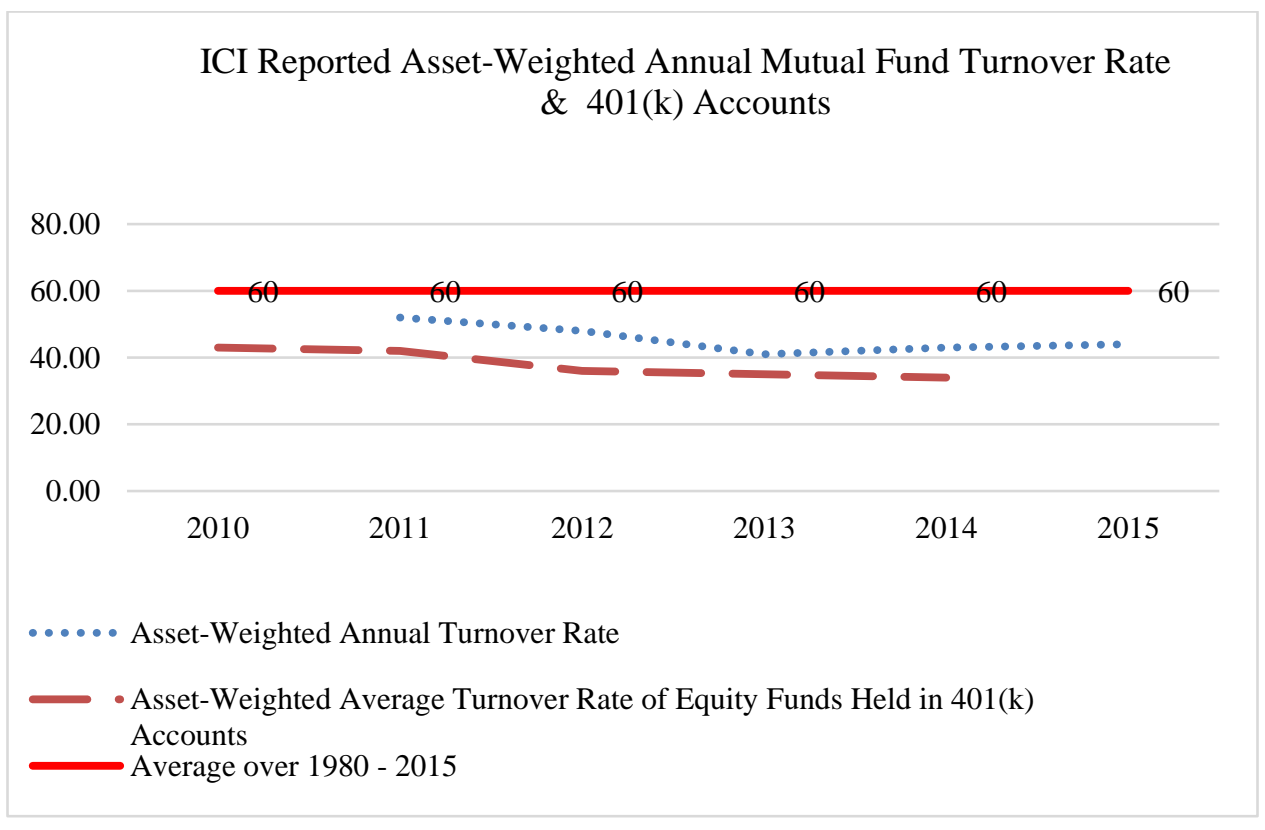

The prior Part documents the argumentative force and weight given to the institutional investors' PTR in policy debates, academic scholarship, and industry reports. Here an important tension is made plain: the PTR is a flawed and incomplete measure of cost and time estimates, ${ }^{152}$ yet, it is the only publicly available measure on mutual fund trading activity, and thus, it is heavily replied upon. ${ }^{153}$ With this duality in mind, we turn to evaluate the claim of continued shortening of time horizons and to compare the picture painted by portfolio turnover ratios with that of alternative measurements.

\section{REMEASURING PORTFOLIO TURNOVER RATIOS}

The current empirical support for any claim of continued decrease in mutual fund time horizons is flimsy and inconclusive at best. New data is needed to ascertain current trends. To contribute to this foundational inquiry, I compile and analyze - using summary statistics ${ }^{154}$ - a dataset of mutual fund portfolio turnover data. In light of the reliability

151. Id. at 37

152. Describing the use of the portfolio turnover ratio by the SEC as "controversial and contested" and describing the turnover ratio as difficult to understand and an imperfect measure. IA Meaningful Disclosure, supra note 28, at 18. See also, Chunhua Lan et al., supra note 85, at 6 (stating that the portfolio turnover ratio "does not describe the rich information that is contained in the heterogeneity of stock holding periods").

153. Legal researchers can obtain the portfolio turnover ratio through SEC filings, Morningstar reports, and compilations produced by the ICI. See, e.g., ICI 2016 FАСтвOOK, supra note 14, at 37.

154. The summary statistics used in this article are primarily focused on averages and distributions. The complexity of the project was derived from the need to compute the alternative measures for each mutual fund in the sample and the resulting size of the dataset. 
concerns catalogued in the previous Part, I segment the data by fund style and objective. I also compare the PTR trends to the results generated by three alternative calculations: Duration, Churn Rate \& Modified Portfolio Turnover Ratio.

\section{A. PTR Data}

The dataset is derived from the CRSP survivor-bias-free U.S. mutual fund database to generate a sample of domestic equity managed mutual funds from 2005 to 2015 . The CRSP database provides fund returns and characteristics such as total assets under management, expense ratio, load, and turnover. Portfolio holdings data of these funds are from the Thomson Reuters S12 database. ${ }^{155}$ The S12 database details the holdings of all mutual funds and reports the fund manager, which is often the reported manager in $13 \mathrm{~F}$ filings as aggregated in the S34 database. ${ }^{156}$ By example, Fidelity would be the reported fund manager for a Fidelity-managed fund like Magellan. Magellan holdings would be reported in the S12 and all of Fidelity's funds, including Magellan, would be aggregated and reported in the S34 database. Another key difference is that $13 \mathrm{~F}$ filings, as made available in the S34, feature mutual funds in addition to other institutional investors such as trust departments at banks and pension funds. The CRSP database and S12 databases are merged using the Wharton Research Data Services' (WRDS) MFLINKS tables, where the Wharton Financial Institution Center Number (WFICN) is the common identifier. This step generates a sample of 2960 unique funds. ${ }^{157}$

The mutual fund industry is not monolithic. Different funds have different investment strategies and asset priorities affecting turnover impact between funds based, in part, on trading styles and objectives. ${ }^{158}$ To account for this, funds are classified as

155. Because I used the $\mathrm{S} 12$ database, I did not link to other categories of investors like transient or quasiindexing like that established in Brian Bushee's work. See e.g., Champagne et al., supra note 76, at 9-12 (describing data sources and posting alternative investor classifications). The S12 database details the holdings of all mutual funds and reports the fund manager, which is often the reported manager in $13 \mathrm{~F}$ filings as aggregated in the S34 database. By example, Fidelity would be the reported fund manager for a Fidelity-managed fund like Magellan. Magallan holdings would be reported in the S12 and all of Fidelity's funds, including Magellan, would be aggregated and reported in the S34 database. Another key difference is that $13 \mathrm{~F}$ filings are made available in the S34 featured mutual funds in addition to other institutional investors such as trust departments at banks, pension funds, etc. User's Guide to Thomson Reuters Mutual Fund and Investment Company Common Stock Holdings Databases on WRDS, WHARTON RES. DATA SERV. (July 2008), https://wrdsweb.wharton.upenn.edu/wrds/support/Data/_001Manuals\%20and\%20Overviews/_004Thomson\%20Reuters/M utual $\% 20$ Fund $\% 20$ and $\% 20$ Investment $\% 20$ Company/WRDS $\% 20$ Overview\%20f\%20Thomson $\% 20$ Reuters $\% 2$ 0Mutual\%20Fund\%20and\%20Investment\%20Company\%20Data.pdf.cfm.

156. Recent research has uncovered missing share classes (up to 58\% of new domestic mutual funds from 2008-2015) from the CRSP Mutual fund Database that are not matched to the Tomson Reuters 12s Mutual Fund Holdings (TR) database, with implications for the ability to aggregate share classes using the MFLinks file. Qifei Zhu, The Missing New Funds (July 2017) (unpublished manuscript), https://ssrn.com/abstract=3004268. The impact of missing share classes is minimal in this project because a fund's PTR does not vary as between share classes and is reported for the fund, as a whole.

157. The number of funds in the dataset is calculated by counting the observations of WFICNS - the unique identifier assigned to each mutual fund in the CRSP database.

158. Chalmers et al., supra note 57, at 3 (describing the different role of portfolio turnover in different style funds and the subsequent impact on performance monitoring research); see also id. at 19 (describing findings as "turnover captures only a portion of the variation in fund trading costs and ... does a relatively poor job of explaining fund returns. Turnover is surely an important determinant of trading costs, but it is just one component."). 
active, index and ETF using the following methods. First, funds are labeled index in this dataset if labeled as such in the CRSP mutual fund database. Second, all fund names were text searched for "index" to identify any potential missed index funds. These two procedures classify 498 funds as index funds. Note that the large-cap funds track with index funds, thus eliminating any potential for active, large-cap funds in this sample. Third, the process was repeated for ETF funds using both CRSP identifier and a word search for "ETF" in the fund name. These sorting procedures classify 221 funds as ETF, which were excluded ${ }^{159}$ from the results reported below. The remaining 2462 funds are active funds.

Mutual funds are further segmented using the CRSP objective code ${ }^{160}$ to sort capbased funds including large cap, mid cap, small cap and micro-cap, and style funds including growth, growth \& income (blended), and income. Segmenting funds isolates effects unique to fund investment strategy, operating company, industry, or assets. For example, Large Cap funds are index funds, whereas Micro cap funds invest in companies with smaller capitalization of \$200-300 million, fewer shares of stock available for sale, and shares of stock sold on over-the-counter exchanges. ${ }^{161}$

\begin{tabular}{|l|l|l|}
\hline All Funds & Active Funds & Index Funds \\
\hline 2960 & 2462 & 498 \\
\hline
\end{tabular}

The following table presents the number of funds by categories and years to provide a sense of the size and breadth of the sample. ${ }^{162}$ Panel A captures all funds; Panel B and $\mathrm{C}$, respectively, capture actively-managed and index funds.

159. ETF funds are technically open-ended mutual funds, but the investors do not buy direct shares of the fund, like with traditional funds. Rather investors acquire shares on a stock exchange and combine the diversification of mutual funds with the liquidity of exchange-traded stocks. See Exchange-Traded Funds (ETFs), SEC (Dec. 6, 2017), https://www.sec.gov/answers/etf.htm.

160. CRSP Style Code, supra note 20.

161. See id.; see also, MicroCap Stock: A Guide for Investors, SEC (Sept. 18. 2013), https://www.sec.gov/investor/pubs/microcapstock.htm.

162. Because my data is rolled up to the fund level, I do not need to restrict the data to stocks with high institutional ownership as is done in other finance studies of portfolio turnovers, nor do I need to restrict observations based upon time on market (to remove issues such as IPO anomalies). $C f$. Cremers \& Pareek, supra note 77 , at 9,11 . 
Table 2:Panels A-C

Panel A: All Funds

\begin{tabular}{|c|c|c|c|c|c|c|c|}
\hline & \multicolumn{6}{|c|}{ Cap-based } & \multicolumn{3}{c|}{ Style } \\
\hline Year & $\begin{array}{c}\text { Micro } \\
\text { Cap }\end{array}$ & $\begin{array}{c}\text { Large } \\
\text { Cap }\end{array}$ & $\begin{array}{c}\text { Mid } \\
\text { Cap }\end{array}$ & $\begin{array}{c}\text { Small } \\
\text { Cap }\end{array}$ & $\begin{array}{c}\text { Growth } \\
\text { \& } \\
\text { Income }\end{array}$ & Growth & Income \\
\hline $\mathbf{2 0 0 5}$ & 39 & 66 & 303 & 479 & 338 & 943 & 62 \\
\hline $\mathbf{2 0 0 6}$ & 42 & 66 & 322 & 483 & 347 & 931 & 67 \\
\hline $\mathbf{2 0 0 7}$ & 44 & 66 & 345 & 503 & 369 & 963 & 80 \\
\hline $\mathbf{2 0 0 8}$ & 45 & 65 & 369 & 520 & 396 & 1015 & 86 \\
\hline $\mathbf{2 0 0 9}$ & 36 & 59 & 333 & 467 & 379 & 959 & 81 \\
\hline $\mathbf{2 0 1 0}$ & 36 & 57 & 314 & 431 & 353 & 909 & 74 \\
\hline $\mathbf{2 0 1 1}$ & 34 & 56 & 298 & 422 & 342 & 877 & 73 \\
\hline $\mathbf{2 0 1 2}$ & 30 & 54 & 283 & 411 & 314 & 816 & 67 \\
\hline $\mathbf{2 0 1 3}$ & 29 & 47 & 264 & 393 & 293 & 766 & 68 \\
\hline $\mathbf{2 0 1 4}$ & 29 & 47 & 256 & 382 & 286 & 724 & 69 \\
\hline $\mathbf{2 0 1 5}$ & 29 & 41 & 231 & 348 & 256 & 676 & 64 \\
\hline
\end{tabular}

Panel B: Actively Managed Funds

\begin{tabular}{|c|c|c|c|c|c|c|c|}
\hline & \multicolumn{5}{|c|}{ Cap-based } & \multicolumn{3}{c|}{ Style } \\
\hline Year & $\begin{array}{c}\text { Micro } \\
\text { Cap }\end{array}$ & $\begin{array}{c}\text { Large } \\
\text { Cap }^{163}\end{array}$ & $\begin{array}{c}\text { Mid } \\
\text { Cap }\end{array}$ & $\begin{array}{c}\text { Small } \\
\text { Cap }\end{array}$ & $\begin{array}{c}\text { Growth } \\
\text { \& } \\
\text { Income }\end{array}$ & Growth & Income \\
\hline $\mathbf{2 0 0 5}$ & 37 & 0 & 262 & 431 & 303 & 845 & 59 \\
\hline $\mathbf{2 0 0 6}$ & 38 & 0 & 277 & 433 & 310 & 834 & 61 \\
\hline $\mathbf{2 0 0 7}$ & 39 & 0 & 293 & 448 & 331 & 852 & 67 \\
\hline $\mathbf{2 0 0 8}$ & 40 & 0 & 312 & 460 & 353 & 877 & 71 \\
\hline $\mathbf{2 0 0 9}$ & 31 & 0 & 280 & 410 & 336 & 829 & 66 \\
\hline $\mathbf{2 0 1 0}$ & 31 & 0 & 262 & 373 & 313 & 777 & 60 \\
\hline $\mathbf{2 0 1 1}$ & 28 & 0 & 247 & 364 & 301 & 748 & 59 \\
\hline $\mathbf{2 0 1 2}$ & 24 & 0 & 231 & 358 & 277 & 688 & 53 \\
\hline $\mathbf{2 0 1 3}$ & 23 & 0 & 212 & 341 & 257 & 642 & 56 \\
\hline $\mathbf{2 0 1 4}$ & 23 & 0 & 205 & 330 & 253 & 605 & 57 \\
\hline $\mathbf{2 0 1 5}$ & 23 & 0 & 181 & 300 & 225 & 566 & 52 \\
\hline
\end{tabular}

163. Note that there is no large cap fund category for active funds because this category matches an index and thus is scored as a passive fund. See CRSP Style Code, supra note 20 (describing Large Cap funds as "SP S\&P 500 Index Objective Funds"). 
Panel C: Index Funds

\begin{tabular}{|c|c|c|c|c|c|c|c|}
\hline & \multicolumn{3}{|c|}{ Cap-based } & \multicolumn{3}{c|}{ Style } \\
\hline Year & $\begin{array}{c}\text { Micro } \\
\text { Cap }\end{array}$ & $\begin{array}{c}\text { Large } \\
\text { Cap }\end{array}$ & $\begin{array}{c}\text { Mid } \\
\text { Cap }\end{array}$ & $\begin{array}{c}\text { Small } \\
\text { Cap }\end{array}$ & $\begin{array}{c}\text { Growth } \\
\text { \& } \\
\text { Income }\end{array}$ & Growth & Income \\
\hline $\mathbf{2 0 0 5}$ & 2 & 66 & 41 & 47 & 35 & 97 & 3 \\
\hline $\mathbf{2 0 0 6}$ & 4 & 66 & 45 & 50 & 36 & 97 & 6 \\
\hline $\mathbf{2 0 0 7}$ & 5 & 66 & 51 & 56 & 38 & 111 & 13 \\
\hline $\mathbf{2 0 0 8}$ & 5 & 65 & 58 & 60 & 43 & 138 & 15 \\
\hline $\mathbf{2 0 0 9}$ & 5 & 59 & 53 & 57 & 43 & 131 & 15 \\
\hline $\mathbf{2 0 1 0}$ & 5 & 57 & 52 & 58 & 41 & 132 & 14 \\
\hline $\mathbf{2 0 1 1}$ & 6 & 56 & 51 & 58 & 41 & 129 & 14 \\
\hline $\mathbf{2 0 1 2}$ & 6 & 54 & 52 & 52 & 37 & 128 & 14 \\
\hline $\mathbf{2 0 1 3}$ & 6 & 47 & 52 & 53 & 36 & 124 & 13 \\
\hline $\mathbf{2 0 1 4}$ & 6 & 47 & 52 & 52 & 33 & 118 & 12 \\
\hline $\mathbf{2 0 1 5}$ & 6 & 41 & 50 & 48 & 31 & 110 & 12 \\
\hline
\end{tabular}

\section{B. Mutual Fund Time Horizon PTR Re-measurement Methodology}

\section{Overview of Measure}

As noted above, all mutual funds report an annual portfolio turnover ratio on the prospectus form N1-A. ${ }^{164}$ The CRSP database compiles reported portfolio turnover ratios - and other information - for uses such as Morningstar mutual ratings, ICI calculations, and other mutual fund data analysis. ${ }^{165}$ The reported PTR, available through the CRSP database, has been the focus of the Article thus far. The portfolio turnover ratio calculation, as introduced in Part II, divides the lesser of the fund's total securities sold or purchased, by its average total net assets. ${ }^{166}$

164. Registration Form Used by Open-End Management Investment Companies, 63 Fed. Reg. 14,814 (June 1, 1998) (codified at 17 C.F.R. pts. 239, 274); see, e.g., SEC Form N-1A, supra note 24, at 2.

165. See, e.g., Turnover Ratio, MoRNINGSTAR http://www.morningstar.com/InvGlossary/turnover_ratio.aspx (last visited Mar. 11, 2018) (explaining mutual fund turnover ratios for use in investment analysis).

166. SEC Form N-1A, supra note 24, at 18. Calculate the Portfolio Turnover Rate as follows:

(i) Divide the lesser of amounts of purchases or sales of portfolio securities for the fiscal year by the monthly average of the value of the portfolio securities owned by the Fund during the fiscal year. Calculate the monthly average by totaling the values of portfolio securities as of the beginning and end of the first month of the fiscal year and as of the end of each of the succeeding 11 months and dividing the sum by 13 .

(ii) Exclude from both the numerator and the denominator amounts relating to all securities, including options, whose maturities or expiration dates at the time of acquisition were one year or less. Include all long-term securities, including long-term U.S. Government securities. Purchases include any cash paid upon the conversion of one portfolio security into another and the cost of rights or warrants. Sales include net proceeds of the sale of rights and warrants and net proceeds of portfolio securities that have been called or for which payment has been made through redemption or maturity.

(iii) If the Fund acquired the assets of another investment company or of a personal holding company 


$$
\text { Portfolio Turnover Ratio }{ }^{167}=\frac{\text { Min(\$Total Sales,\$Total Purchases) }}{\text { Avg.TNA }}
$$

The portfolio turnover ratio captures trading activity when a manager either sells or purchases assets. The measure does not consider cases where buys are higher than sales due to fund inflows or where sales are higher than buys due to net outflows.

\section{General Portfolio Turnover Ratio Trends}

As illustrated in Figure 2, the mean portfolio turnover ratio for all mutual funds from $2005-2015$ was $79.87 \%$. If a fund turns over approximately $79 \%$ of its stock holding each year, a mutual fund investor is likely to hold onto stock, on average, for a little over 15 months.

One critique of the portfolio turnover ratio is that is does not account for different investment strategies. Breaking the portfolio turnover ratio trends down between active and index funds produced respective means of $79.98 \%$ and $79.35 \%$. The common wisdom might have predicted that active funds have higher trading activity than indexed (passively managed funds), but the mean portfolio turnover ratio for the sample between 2005-2015 shows that the index fund sub-group had higher turnover ratios than active funds in 2005, 2009, 2010, 2012, and 2015. ${ }^{168}$ Differences between active and index funds' PTR are observable in the distribution of the mean where the median PTR is $60 \%$ for active funds and $28 \%$ for index funds. The following figure reports the mean for all funds, all active and all index funds using the CRSP turnover ratio from 2005-2015.

in exchange for its own shares during the fiscal year in a purchase-of-assets transaction, exclude the value of securities acquired from purchases and securities sold from sales to realign the Fund's portfolio. Adjust the denominator of the portfolio turnover computation to reflect these excluded purchases and sales and disclose them in a footnote.

(iv) Include in purchases and sales any short sales that the Fund intends to maintain for more than one year and put and call options with expiration dates more than one year from the date of acquisition. Include proceeds from a short sale in the value of the portfolio securities sold during the period; include the cost of covering a short sale in the value of portfolio securities purchased during the period. Include premiums paid to purchase options in the value of portfolio securities purchased during the reporting period; include premiums received from the sale of options in the value of the portfolio securities sold during the period.

167. This formula was first provided in Part II and expressed as the "Lesser of Purchases or Sales" divided by the "Average Fund Value over 12 months." See supra notes 26,28 and accompanying text.

168. The similarity between active and index funds may be explained, in part, by closet or shadow indexing, a practice where active funds closely follow an index. Closet indexing may account for as much as $30 \%$ of the active mutual fund market. The Rise of Closet Indexers, МкT. WATCH (Mar. 1, 2011, 1:18 PM), http://www.marketwatch.com/story/the-rise-of-the-closet-indexers-1298676720501. 
Figure 2

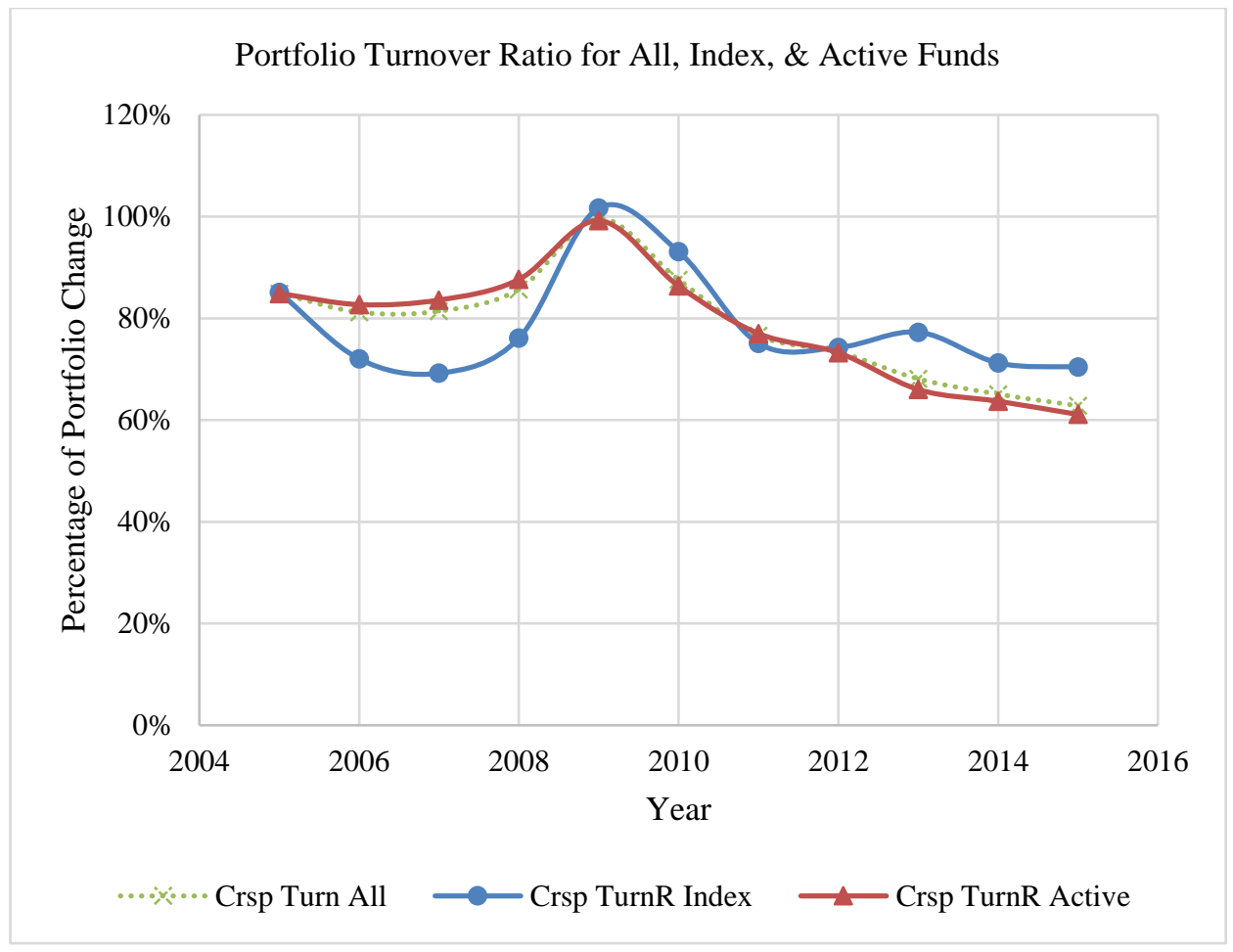

In all cross sections of funds, the portfolio turnover ratio declined when measured at 2005 and 2015. The portfolio turnover ratio numbers peaked in 2009 following the financial crisis and steadily decreased from the high-water mark through 2015, to numbers below where they were in 2005. These trends are inconsistent with claims of continually decreasing mutual fund investment time horizons and consistent with ICI reported figures.

An asset-weighted mean was calculated for this dataset to compare findings with those of the ICI. Asset-weighted means add texture to the simple mean by preventing over amplification of mutual fund market segments. The simple average collects one PTR for each fund regardless of the fund's size (and therefore likely market impact). In this way, five funds with smaller assets ( $\$ 100$ million) contribute five portfolio turnover ratios to the calculation whereas a larger mutual fund of $\$ 1$ billion assets would contribute one portfolio turnover ratio to the mean calculation. A simple average can amplify the role of lower asset funds: the $\$ 500$ million assets held in the five smaller funds affect the mean more than the $\$ 1$ billion assets held in the single fund despite differences in scale. The weighted average matches portfolio turnover ratios with assets to trade and may be a more meaningful lens into market-wide trends. Understanding market trends are central to examining the underlying narrative that mutual fund shorttermism is a contagion infecting operating company time horizons.

The asset-weight calculation for each mutual fund divided the fund's total net assets (tna) by the sum of all funds' (within the category) total net assets. A fund's PTR was 
multiplied by the asset-weight to generate the asset-weighted PTR. The following illustrates the calculation; Table 3 reports the results for all active mutual funds in the dataset.

$$
\begin{gathered}
\text { Fund }_{\mathrm{j}} \text { weight }=\frac{\text { Fund }_{\mathrm{j}} \text { tha }}{\sum \text { all fund tna }} \\
\text { Asset weighted PTR Fund } \text { Fueight }_{\mathrm{f}}=\text { PTR }
\end{gathered}
$$

Table 3: Portfolio Turnover Ratio Weighted Mean for Active Funds 2005-2015

\begin{tabular}{|c|c|c|c|c|c|c|c|c|c|c|}
\hline $\mathbf{2 0 0 5}$ & $\mathbf{2 0 0 6}$ & $\mathbf{2 0 0 7}$ & $\mathbf{2 0 0 8}$ & $\mathbf{2 0 0 9}$ & $\mathbf{2 0 1 0}$ & $\mathbf{2 0 1 1}$ & $\mathbf{2 0 1 2}$ & $\mathbf{2 0 1 3}$ & $\mathbf{2 0 1 4}$ & $\mathbf{2 0 1 5}$ \\
\hline 52.9 & 55.8 & 56.2 & 58.5 & 66.0 & 58.9 & 53.3 & 48.7 & 42.6 & 42.6 & 41.3 \\
$\%$ & $\%$ & $\%$ & $\%$ & $\%$ & $\%$ & $\%$ & $\%$ & $\%$ & $\%$ & $\%$ \\
\hline
\end{tabular}

Under the asset-weight, mutual funds held assets for, on average 23 months. ${ }^{169}$ The longer holding period indicates that larger funds hold assets longer than smaller funds. Between 2005-2015 the asset-weighted mean PTR rose initially, then dropped from 53\% in 2005 to $41 \%$ in 2015 meaning that holding periods increased. In 2005, mutual funds held assets for less than 2 years, but held assets for more than 2 years in 2015. The assetweighted portfolio turnover ratio followed a pattern consistent with an unweighted PTR evaluation, peaking in 2009 following the financial crisis and consistently declining thereafter. The results of the weighted average further mute the narrative that mutual fund short-termism is increasing, a claim that warrants further discussion in the conclusions offered in Part V.

Public mutual fund portfolio turnover ratios - whether simple or asset-weighted — do not demonstrate a clear upward trend over the eleven year window observed in this dataset that would support a narrative of accelerated short-termism. Instead, what we see is somewhat chaotic performance with a large impact following the financial crisis in $2009^{170}$ and a general decline in turnover since 2010 .

Table 4 shows the distribution of the (unweighted) PTR mean from 2005-15 by standard deviation (sd) and quartiles (p25, p50 and p75). Distribution of the (unweighted) PTR mean is skewed left rather than normally distributed, indicating that funds with higher portfolio turnover may act as outliers skewing (augmenting) the mean. This is particularly evident with index funds where the median PTR was $28 \%$, but the mean was $79.35 \%$. Additional graphs of the mean, with a year-by-year breakdown of distributions are included in Appendix 5.

169. The ICI reported equity fund asset-weighted means in 2015 as $44 \%$, a slightly higher number than produced in this sample that may be attributed to incorporating index funds along with actively managed funds in the ICI sample. Readers may take note that the ICI only reports the asset-weighted PTR average. ICI 2016 FАСТВОOK, supra note 14, at 37.

170. The financial crisis effect demonstrates PTR insensitivity to fund flow and pricing impacts. 
Table 4:_Unweighted PTR 2005-15 Mean Distribution ${ }^{171}$

\begin{tabular}{|c|c|c|c|}
\hline Metric & Crsp_PTR \% & Crsp_PTR \% & Crsp_PTR \% \\
\hline $\begin{array}{c}\text { Fund } \\
\text { Type }\end{array}$ & All Funds & Active Funds & Index Funds \\
\hline Mean & $79.87 \%$ & $79.98 \%$ & $79.35 \%$ \\
\hline Sd & 1.246955 & 1.159055 & 1.604844 \\
\hline Count & 88056 & 72940 & 15116 \\
\hline p25 & $27.00 \%$ & $32.00 \%$ & $11.00 \%$ \\
\hline p50 & $55.00 \%$ & $60.00 \%$ & $28.00 \%$ \\
\hline p75 & $97.00 \%$ & $100.00 \%$ & $75.00 \%$ \\
\hline
\end{tabular}

\section{Trends by Fund Cap \& Style Codes}

Noting the criticism of the portfolio turnover ratio regarding insensitivity to fund objectives and investment strategy, I sorted portfolio turnover ratios for all active funds by six style and objective codes.

In Figure 3 below, the flat (solid) line reveals the 11-year average mean portfolio turnover ratios for all active funds. The portfolio turnover means organized by style code contextualize turnover trends. Figure 3 charts the portfolio turnover means by style code and paints a picture consistent with the story of unsegmented portfolio turnover ratios (Figure 2). Mutual funds experienced portfolio turmoil (whether due to investor withdrawals or rebalancing because of the market) in 2009 following the financial crisis. In all six sub-categories, portfolio turnover ratios declined after 2010 and demonstrated a net decrease from the 2005 starting point. The income and growth \& income (also called blended funds) categories have the lowest observable portfolio turnover ratio. Those funds experienced less holdings volatility, noting that their 11-year trend lines were nearly flat so that the ending 2015 percentage was close to the original starting point in 2005. Growth funds experienced the greatest volatility and recorded the highest peak PTR of over $110 \%$.

171. Table 4 lists the Mean, the Standard Deviation (Sd), the number of observations (Count), and the quartiles of distributions at 25\% (p25), 50\% (p50), and 75\% (p75). The 50\% is the median. 
Figure 3

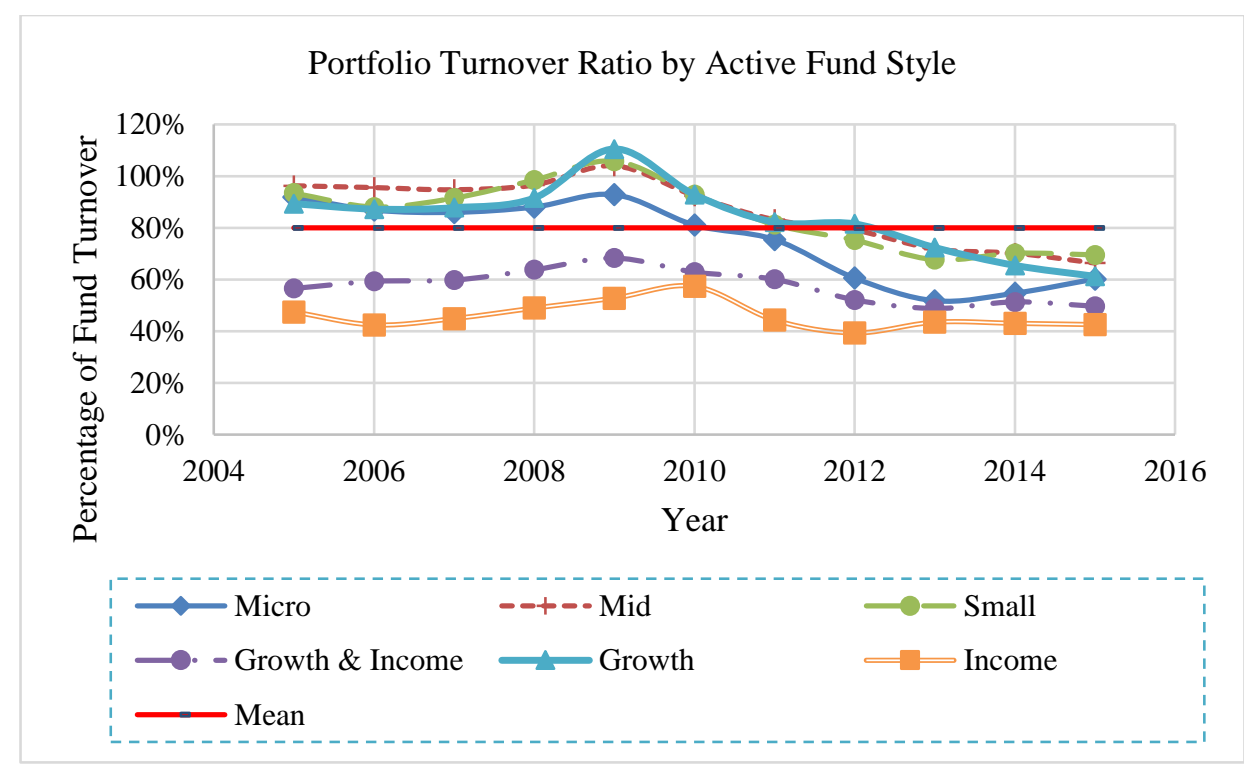

Mutual fund investment time horizons, measured by the PTR from 2005-15, do not show increased mutual fund short-termism. The decreasing turnover ratios suggest that time horizons are chaotic, subject to market volatility and, if anything, lengthening. This observation holds true for index funds and all segments of active funds. Having answered the first inquiry of the Article - what can we observe about mutual fund investment time horizons between 2005-15 using the PTR - we can turn to the second inquiry: how strong is the PTR signal?

\section{Robustness Checks: Alternative Measures of Mutual Fund Investment Time Horizons}

Borrowing from finance literature, I identify three alternative measures of mutual fund portfolio changes: Duration, Churn Rate, and Modified Portfolio Turnover. These measures address concerns raised with the PTR as an incomplete measure of time horizon or transaction costs. Additionally, these alternative measures may validate or undermine the descriptive power of the PTR. By incorporating alternative measures, I indirectly test the strength of the time horizon signal created by the PTR measure. Recall a central hypothesis of this project: if PTRs provide a valuable signal of mutual fund investment time horizon, then the alternative measures will perform similar to the PTR and with observable correlations. If, on the other hand, PTRs generate trends inconsistent with the alternative measures and without a correlation, this may discount the signaling value of the PTR for mutual fund time horizons.

All the alternative measures utilize historical data for the calculation. As such, from my sample of mutual fund activity from 2005-15, the three alternative measures are calculated from 2005-14, not 2015 . $^{172}$

172. For example, consider, "investor turnover uses a one-year history of information on the behavior of 


\section{Duration Measure}

The first alternative measure to the portfolio turnover ratio is the Cremers \& Pareek Duration measure ("Duration"). ${ }^{173}$ The Duration measure differs from the PTR because it is a direct measure (not an approximation) of how long a mutual fund, on average, holds its actual stock portfolio over a five-year period. ${ }^{174}$ The direct measurement eliminates the over- and under-inclusive criticisms of the PRT. Duration also importantly "allows for heterogeneity" in a mutual fund's investment time horizon recognizing that a fund may have both long and short positions in its portfolio. ${ }^{175}$ Duration has an inverse relationship to the PTR. An increasing PTR signaled shorter holding periods, but an increasing Duration measure means that funds are holding onto portfolio assets for longer.

To calculate Duration, compute the holding duration at the stock-institution level for all the stocks in each institutional investors' portfolio, i.e. the weighted number of years the stock had been held in the last five years in the portfolio. ${ }^{176}$ To do this Cremers \& Pareek calculated a weighted measure of the buys and sells by a fund over a period of time (20 quarters), weighted by the length of time the stock was held. It asks how long an institutional investor held a given stock continuously in the portfolio. The measure then generates an average of individual stock holding patterns for each mutual fund. ${ }^{177}$

The equation for stock $i$ duration held by institutional portfolio $j$ at time T-1 is:

$$
\text { Duration }{ }_{i, j, T-1}=d_{i, j . T-1}=\sum_{t=T-W}^{T-1}\left(\frac{(T-t-1) \alpha_{i, j, t}}{H_{i . j}+B_{i . j}}\right)+\frac{(W-1) H_{i . j}}{H_{i, j}+B_{i . j}}
$$

where:

$B_{i, j}=$ total percentage of shares of stock $i$ bought by institution $j$ between $\mathrm{t}=\mathrm{T}$ $\mathrm{W}$ and $\mathrm{t}=\mathrm{T}-1 ; \mathrm{t}, \mathrm{T}$ are in quarters.

$H_{i, j}=$ percentage of total shares outstanding of stock $i$ held by institution $j$ at time $\mathrm{t}=\mathrm{T}-\mathrm{W}$.

$\alpha_{i, j, t}=$ percentage of total shares outstanding of stock $i$ bought or sold by institution $\mathrm{j}$ between time $\mathrm{t}-1$ and $\mathrm{t}$, where $\alpha_{i, j, t}>0$ for buys and $<0$ for sells. ${ }^{178}$

investors." Gaspar et al., supra note 120, at 143.

173. Cremers \& Pareek, supra note 77 , at 1651 . The Duration measure was produced in conjunction with a study on short-term trading impact on stock prices. Id. at 1655 . The authors considered four proxies of short-term trading: stock turnover, percentage of transient investors, fund turnover (the "Churn" measure which is alternative \#2) and a new measure they call Stock Duration.

174. Id.

175. Id. at 1654

176. Id. at $1651 \mathrm{n} .2$. For each stock, they aggregated the duration across all institutions using $13 \mathrm{~F}$ holding reports. I examine the holding patterns of institutions in this Article and did not utilize $13 \mathrm{~F}$ holding reports to aggregate the measure at the operating company stock level.

177. This measure is unique and different from classifying funds as long or short term like the Bushee classifications, which ascribe homogenous holding patterns to certain investors. The duration measure considers that a single investor may have long-term and short-term positions on securities within investor's portfolio and creates a unique measure reflecting the average holding pattern for that investor. Bushee, Do Institutional Investors, supra note 108, at 221.

178. Cremers \& Pareek, supra note 77, at 1659-60. The authors illustrate the impact of the calculation as follows: Suppose the institutional portfolio of Fidelity owns two stocks: IBM and Ford. It owns $5 \%$ of total shares of IBM, $2 \%$ of which it bought 3 quarters back, with the remaining $3 \%$ shares bought 5 quarters back. The 
Cremers and Pareek chose to make the $\mathrm{W}$ (the timing) to be 20 quarters, or 5 years, to isolate the behavioral effects. ${ }^{179}$ Duration $=0$ "if [the] stock $i$ is not in the institutional portfolio $j$ at time T-1."180

To compute Duration ${ }^{181}$ for each institutional fund $j$, I averaged Duration $_{i, j, T-1}$ for all operating company stocks held by each fund to calculate each institution's total weighted portfolio duration.

Because the measure is based upon quarterly holdings reports, the Cremers \& Pareek Duration measure ignores intra-quarterly trading, rendering most high frequency trading invisible in the measure. ${ }^{182}$ It also takes into account tax selling and temporary portfolio adjustments where immediate buybacks cancel intermediate sells, creating a small effect on the current holdings' duration. ${ }^{183}$ The Cremers \& Pareek study looked at fund flows to evaluate whether stock duration was influenced by in-flows where funds had to scale up or conversely out flows whereby funds scaled down. ${ }^{184}$

\section{a. General Duration Trends}

The mean Duration for all funds in the dataset from $2005-14^{185}$ was 15.15 months. ${ }^{186}$ Table 5 shows the distribution of the average 2005-14 Duration mean

weighted age of IBM today in Fidelity's portfolio is $(2 \% / 5 \% \times 3$ quarters $+3 \% / 5 \% \times 5$ quarters $)=4.2$ quarters. Also, suppose it currently owns $1 \%$ shares of Ford, having bought $5 \%$ shares 6 quarters back and having sold $4 \%$ of them 1 quarter back. At this point, the portfolio has thus held $1 \%$ for 6 quarters, but previously held another $4 \%$ for 5 quarters, such that over the past 5 years the weighted average duration (weighted across the percentages of stock owned over time) of Ford is thus $(4 \% / 5 \% \times 5$ quarters $+1 \% / 5 \% \times 6$ quarters $)=5.2$ quarters. Similarly, we calculate this duration measure for every stock-institutional investor pair. The measure thus represents the weighted duration of the holding experience that the institutional investor had in its past for a given stock currently in its portfolio. Id. at 1660 .

179. Despite the 11-year dataset constructed for this study, the 20 quarter or 5-year W value was retained. As Cremers and Pareek explain, the literature was not clear on the ideal value of $\mathrm{W}$ or time period over which to calculate holding changes and their reasoned approach was 5 years. Without reason to change it, I retained the 5 year value. $I d$. at 1660 .

180. Id.

181. In the Cremers \& Pareek measure, fund means the investment management company and not the individual mutual fund. Id. at 1660-61. In contrast, in this Article, the duration measure was calculated for each individual mutual fund utilizing the S12 database rather than the S34 database of 13F filings.

182. Cremers \& Pareek, supra note 77 , at 1654

183. Id. at 1660

184. Id. at 1665-66. Cremers and Pareek, in their study, confirmed that Stock Duration was not driven by fund in and out flows, but by management strategy for their sample from 1985-2010. Id. Cremers and Pareek calculated price pressures created by fund flows following the Coval and Stafford (2007) method. See Joshua Coval \& Erik Stafford, Asset Fire Sales (and Purchases) in Equity Markets, 86 J. FIN. ECON. 479, 481 (2007) (introducing price pressure calculations). Cremers and Pareek also demonstrated that portfolio turnover and stock duration are not highly correlated. "[T]urnover ... increased steadily . . . over the years whereas the variation in Stock Duration [was] cyclical and holdings duration has only slightly lengthened over time." Cremers \& Pareek, supra note 77, at 1661. This measure is based on quarterly holding changes and is like the Gaspar 2005 measure or measure \#2 in this Article. "Stock Duration is negatively correlated with [stock] turnover, with a [-57\%] rank correlation" and - 66\% with fund turnover. Id. at 1662-63.

185. Note that I was unable to calculate Duration for 2015 due to incomplete information available at the time of the data collections. This is true for all the alternative measures - the sample calculations end at 2014. Only the CRSP Turnover Ratio (portfolio turnover ratio) is available for 2015.

186. Cremers and Pareek found a median duration of "close to one and a half years and very stable" over the 
including standard deviation (Sd) and quartiles (p25, p50, and p75). Appendix 5 includes graphs of the average 2005-2014 Duration mean distribution and by-year distributions.

Table 5: Duration 2005-2014 Mean Distribution ${ }^{187}$

\begin{tabular}{|c|c|c|c|}
\hline & Duration (months) & Duration (months) & Duration (months) \\
\hline Metrics & All Funds & Active Funds & Index Funds \\
\hline Mean & 15.12 & 14.03 & 20.53 \\
\hline Sd & 8.719337 & 7.482246 & 11.82 \\
\hline Count & 67691 & 56291 & 11400 \\
\hline $\mathrm{p} 25$ & 8.951331 & 8.804197 & 10.32 \\
\hline $\mathrm{p} 50$ & 13.09455 & 12.59 & 18.92 \\
\hline $\mathrm{p} 75$ & 19.04941 & 17.53339 & 29.87 \\
\hline
\end{tabular}

For the sample period, the Duration measure for mutual funds generally increased. For example, in the dataset, the Duration measure steadily rose for all funds from 14.11 months to 17.39 months between 2005-2014. For active funds, the Duration measure began at 12.85 months in 2005, and concluded at 16.44 months in 2014. Duration trends show little impact from the financial crisis compared with the portfolio turnover ratios. The Duration measure incorporates five years of historical data and thus has a smoothing effect on market shocks - even significant ones like the financial crisis. The Duration measure produced greater variability as between index and active funds than observable under the PTR; likely because Duration is a direct measure and therefore more precise. Index funds decreased in Duration measure from 2005 ( 23.9 months) to 2014 (21.33 months) suggesting that, on average, index funds held portfolio stock for 2 months less in 2014 than in 2005. The index fund trend line displays a significant drop in 2009 following the financial crisis, and remained at an 18-month average Duration through 2010 and then steadily increased through 2014. This trend line suggests that index funds may continue to increase Duration and lengthen stock holding patterns, absent a significant market shock. This also suggests that fund flow and pricing effects may be observed more directly in index funds, rather than active funds. These results are depicted in Table 6 and Figure 4 below.

5-year time period. Cremers \& Pareek, supra note 77, at 1661. For purposes of comparison, the Cremers \& Pareek study eliminated all "stocks in the bottom institutional ownership tercile" and "stocks in the bottom NYSE quintile from the sample." Id. at 1656. They also required all stock and institutional investors to be active for at least two years to be included in the sample. $I d$. at 1656. None of these exclusions applied in my study.

187. Table 5 lists the Mean, the Standard Deviation ( $\mathrm{Sd}$ ), the number of observations (count), and the quartiles of distributions at 25\% (p25), 50\% (p50), and 75\% (p75). 
Table 6: Duration Measure Mean by Year

\begin{tabular}{|c|c|c|c|}
\hline Year & All Funds Duration & $\begin{array}{c}\text { Index Funds } \\
\text { Duration }\end{array}$ & $\begin{array}{c}\text { Active Funds } \\
\text { Duration }\end{array}$ \\
\hline 2005 & 14.11 & 23.9 & 12.85 \\
\hline 2006 & 13.96 & 23.04 & 12.66 \\
\hline 2007 & 14.47 & 22.21 & 13.51 \\
\hline 2008 & 14.72 & 21.85 & 13.44 \\
\hline 2009 & 14.18 & 18.45 & 13.21 \\
\hline 2010 & 14.44 & 18.07 & 13.59 \\
\hline 2011 & 15.27 & 19.43 & 15.45 \\
\hline 2012 & 16.29 & 19.78 & 15.81 \\
\hline 2013 & 16.68 & 20.25 & 16.44 \\
\hline 2014 & 17.39 & 21.33 & \\
\hline & $*$ note, Duration measure reported in months & \\
\hline
\end{tabular}

Figure 4

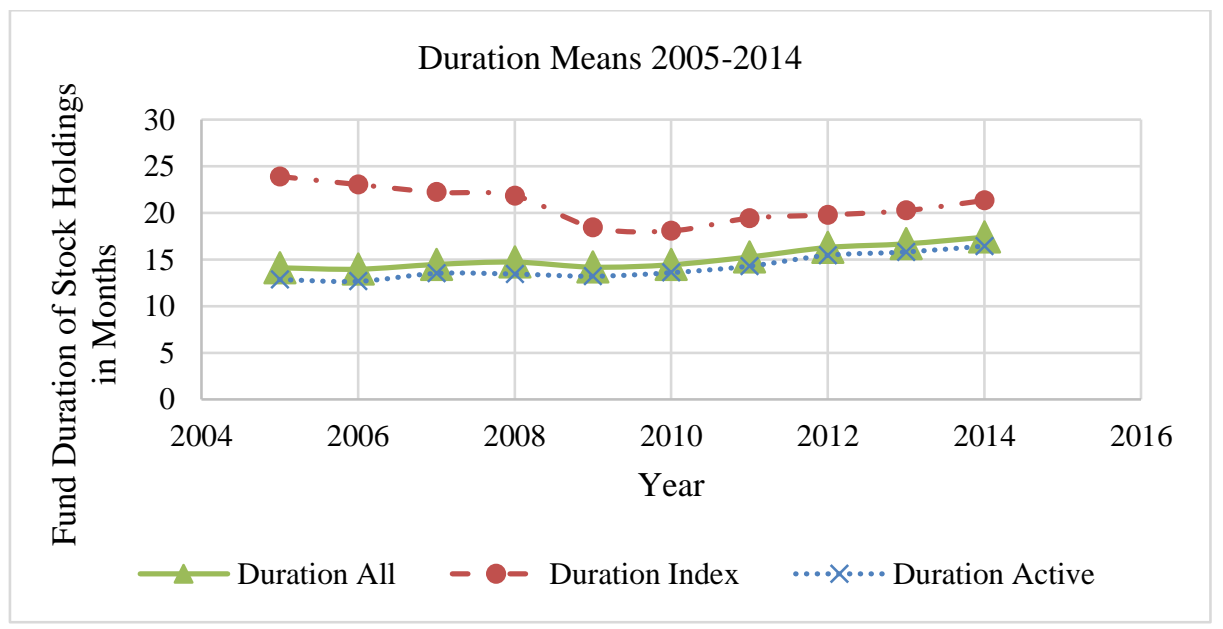

\section{b. Duration Trends by Style and Cap Codes}

The same questions about sensitivity to trading objectives in different styles of funds applies to the Duration measure as it did to the PTR. Accordingly, I segmented the Duration measures for active funds into six categories of funds-micro cap, mid cap, small cap, Growth and Income (blended), Growth, and Income funds - using the CRSP style objective code. In the segmented cross section, the effect of the 2009 financial crisis is further muted, and the upward trend is clear. 
Figure 5

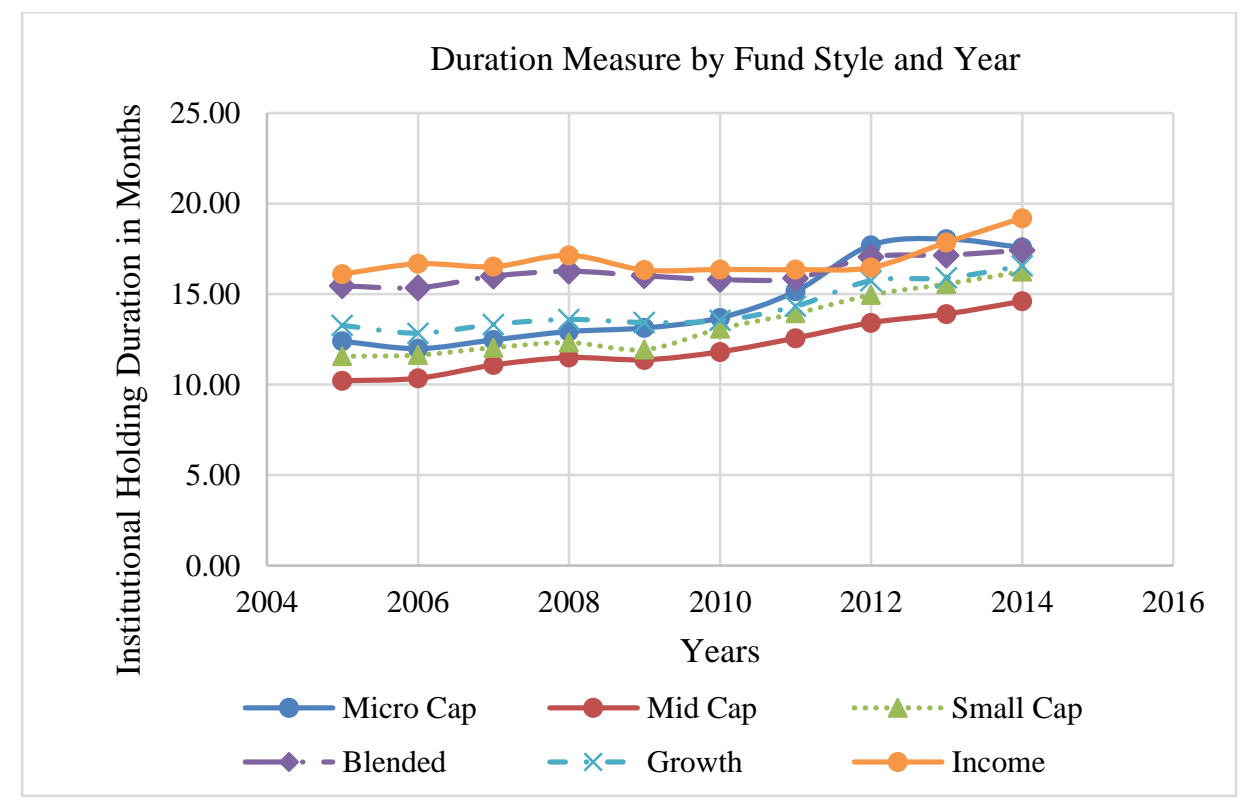

The Duration measure, as applied to mutual funds between 2005-14, does not establish that mutual fund investment time horizons are shortening. The observable increase in the Duration measure across the mutual fund sample from 2005-14, is significant given earlier findings that this measure is not driven by fund flow, and thus aims to reflect a holding strategy rather than a liquidity driver. ${ }^{188}$ The consistency between the trends established in the Duration measure and the portfolio turnover ratio, may support the estimates provided by the PTR - a measure criticized for its bluntness.

\section{Churn Rate}

The second alternative measure of mutual fund time horizons is the Churn Rate. ${ }^{189}$ The Churn Rate is an estimated average of an investor's entire portfolio turnover. ${ }^{190}$

188. Cremers \& Pareek, supra note 77, at 1666.

189. Gaspar et al., supra note 120, at 136. Gaspar used institutional holdings data to infer investment horizons based upon portfolio turnover and explore the relationship between investor time horizons and managerial monitoring and negotiation in acquisitions. The hypothesis of the paper was that short-term shareholders would have weaker incentive to monitor managers thus making the firms more likely the target of an acquisition and that short-term shareholders would be correlated with lower premiums for the target firms held by them. They also hypothesized and observed a correlation between short-term shareholders and the likelihood of bid acceptance. Their findings were consistent with their hypothesis. Id. at 137-38.

190. Id. at 142 ("A short-term investor should buy and sell his investments frequently, while a long-term investor should hold his positions unchanged for a considerable length of time. To implement this idea empirically, I calculate for each institutional investor a measure of how frequently he rotates his positions on all the stocks of his portfolio (churn rate)."). 
Gaspar observed in their 1980-99 sample, a median holding pattern of fifteen months. ${ }^{191}$ The Churn Rate separates transactions generated from fund flow (which would be proportional across all assets) from discretionary trading by comparing asset allocation weights for transactions compared to the portfolio as a whole. ${ }^{192}$ The Churn rate attempts to address the fund flow sensitivity critique levied against the PTR. ${ }^{193}$ Like the Duration measure, the Churn rate should also render high frequency trading invisible because it is a quarterly snap shot of trading that does not reflect transactions held for less than a quarter. $^{194}$

The Churn Rate produces a measure of how frequently the position of portfolio stocks rotated for each mutual fund. ${ }^{195}$ This measure produces the weighted average turnover of an institutional investor's holding of a given stock. ${ }^{196}$ The average turnover is calculated using changes in the quarterly holdings over the past four quarters, and the weights are calculated using the current holdings of each fund. ${ }^{197}$ The Churn rate calculation is:

$$
\text { Churn }=\mathrm{CR}_{\mathrm{i}, \mathrm{t}}=\frac{\sum_{\mathrm{j} \in \mathrm{Q}}\left|\mathrm{N}_{\mathrm{j}, \mathrm{i,t}} \mathrm{P}_{\mathrm{j}, \mathrm{t}}-\mathrm{N}_{\mathrm{j}, \mathrm{i}, \mathrm{t}-1}-\mathrm{P}_{\mathrm{j}, \mathrm{t}-1}-\mathrm{N}_{\mathrm{j}, \mathrm{i}, \mathrm{t}-1} \Delta \mathrm{P}_{\mathrm{j}, \mathrm{t}}\right|}{\sum_{\mathrm{j} \in \mathrm{Q}} \frac{\mathrm{N}_{\mathrm{j}, \mathrm{i}, \mathrm{t}} \mathrm{P}_{\mathrm{j}, \mathrm{t}}+\mathrm{N}_{\mathrm{j}, \mathrm{i}, \mathrm{t}-1} \mathrm{P}_{\mathrm{j}, \mathrm{t}-1}}{2}}
$$

Where, investor $=i$ and the set of companies held by the investor is $Q$ at quarter $t$. Where $P_{j, t}$ and $N_{j, i, t}$ represent the price and the number of shares, respectively, of company $j$ held by institutional investor $i$ at quarter $t .{ }^{198}$

The Churn Rate produces a quarterly transaction estimate. To compare the Churn Rate with the other annual measures, I generated an average annual Churn Rate. ${ }^{199}$ To

191. "Almost $20 \%$ of the portfolio is churned in a quarter, or around $80 \%$ of the position is turned over in a given year. In other words, the median investor is holding an average stock in his portfolio for a period of around $12 / 0.8=15$ months." Id. at 144 . They organized the firms based upon high or low investor turnover as noted by top and bottom $1 / 3$ of the distribution. $I d$. at 149 . They observed a median quarterly Churn rate of $39 \%$. Id. at 145 .

192. Id. at $136-38$.

193. Gaspar et al., supra note 120, calculated the Churn rate across investors' overall portfolios to minimize the possibility that an increase in traded volume of a single company would skew results.

194. The Churn Rate may not be skewed or distorted by high frequency trading, but it does not capture all portfolio transactions.

195. Yan and Zhang studied institutional investor time horizons producing results suggesting that short-term institutions are better informed and that they trade to exploit their information advantage. To test the relationship, the authors constructed a time horizon estimate like the Gaspar Churn rate to sort investors into long and shortterm time horizon categories. Their alternative measure is close to the PTR because it takes the minimum of aggregated purchases and sales - the Churn ( $\min )$ Rate. They found results consistent with other studies that the presence of the institutional investors in companies correlates to positive company stock returns. They found that the "predictive power of total institutional ownership is completely subsumed by short-term institutional ownership" and supports the authors' hypothesis that short-term institutions are (better) informed. An alternative explanation is that short-term institutional investors pressured the companies for higher returns at the expense of long-run firm value. They extended the financial return review to three years to test the durability of the returns, and observed no difference in the extended time review, although not all negative impacts may be discernable at three years. Xuemin (Sterling) Yan \& Zhe Zhang, Institutional Investors and Equity Returns: Are Short-term Institutional Better Informed? 22 REV. FIN. STUD. 893, 893-97 (2009).

196. Gaspar et al., supra note 120 , at 143 .

197. Cremers \& Pareek, supra note 77.

198. Gaspar et al., supra note 120 , at 143

199. The average annual Churn Rate should also mitigate quarterly effects such as fiscal year-end. 
illustrate, for each mutual fund in the data set for the year 2005, there are four churn rates. ${ }^{200}$ An average of the four quarterly churn rates for 2005 create an average quarterly churn rate for each quarter of each observation year. ${ }^{201}$

Using the Churn Rate, fund turnover is calculated at the institutional investor level, and the number is not derived from the fund-stock data such as that used in the Duration measure. ${ }^{202}$ Additionally, the fund Churn Rate does not accommodate heterogeneity in the investment horizon across different stocks in a given institutional portfolio. ${ }^{203} \mathrm{In}$ other words, this measure could label a fund as short or long term, whereas fund-stock level calculations like the Duration measure allows for the same investor to have both long and short holding patterns recognized in different stocks.

\section{a. Churn Rate General Trends}

The mean Churn Rate for all funds in this dataset was $29.83 \%$ per quarter, which equates to approximately $117 \%$ turnover in a year or an average holding time of 10.25 months active funds had a quarterly Churn Rate of $30.79 \%$. The shorter holding periods under this measure suggest strategy-based trading occurs more frequently than fund flow trading. Isolating index funds, the Churn Rate is $25.16 \%$ per quarter or roughly $100 \%$ (over 12 months). A larger observable difference between active and index funds was expected considering the goal of isolating strategy-based trading from fund flows. Table 7 shows the distribution of the 2005-2014 Churn Rate mean including standard deviation (sd) and quartiles (p25, p50, and p75). Appendix 5 graphs the average 20052014 Churn Rate mean distribution for the sample and by-year distributions.

Table 7: Quarterly Churn Rate 2005-2014 Mean Distribution ${ }^{204}$

\begin{tabular}{|c|c|c|c|}
\hline Metrics & $\begin{array}{c}\text { Churn Rate All } \\
\text { Funds }\end{array}$ & $\begin{array}{c}\text { Churn Rate Index } \\
\text { Funds }\end{array}$ & $\begin{array}{c}\text { Churn Rate Active } \\
\text { Funds }\end{array}$ \\
\hline Mean & $29.83 \%$ & $25.16 \%$ & $30.79 \%$ \\
\hline Sd & 0.2140226 & 0.2465657 & 0.2053891 \\
\hline Count & 59111 & 10081 & 49030 \\
\hline p25 & $15.18 \%$ & $7.48 \%$ & $17.11 \%$ \\
\hline p50 & $25.26 \%$ & $15.77 \%$ & $26.39 \%$ \\
\hline p75 & $38.55 \%$ & $34.80 \%$ & $39.06 \%$ \\
\hline
\end{tabular}

200. See Appendix 4 for the quarterly calculations for this measure.

201. To observe the effect of generating an annual number, through the study, I calculated the quarterly churn rate and the average quarterly churn rate. Seeing little variance, I report the annual average below and include the un-aggregated figures in Appendix 4.

202. Gaspar et al., supra note 120 , at 143-44.

203. Cf. Cremers \& Pareek, supra note 77, at 1654.

204. Table 7 lists the Mean, the Standard Deviation (Sd), the number of observations (Count), and the quartiles of distributions at 25\% (p25), 50\% (p50), and 75\% (p75). 
Over the sample time period 2005-14, the Churn rate for all funds, index and active decreased meaning that funds adjusted their portfolios less frequently in 2014 than in 2005. Similar with the portfolio turnover ratio and Duration measures, the Churn Rate spikes after the financial crisis, but the observable change (1-2 percentage points) for the quarterly $^{205}$ estimate was spread out between 2008-10.

\section{Figure 6}

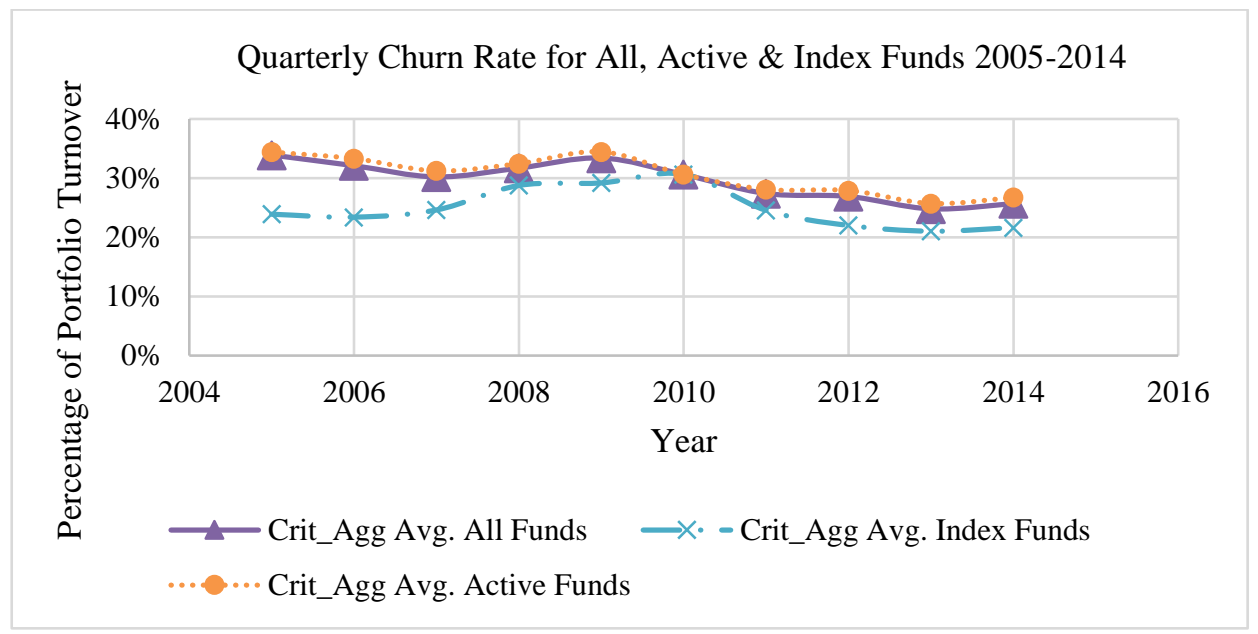

\section{b. Churn Rate Trends by Fund Style \& Cap Codes}

More volatility was observed with the Churn Rate in active funds broken up by style/objective codes than with other measures. Similar with other measures, the Churn Rates spiked in 2009 and generally decreased through 2014. Notably, the Micro-Cap, Mid-Cap, Small-Cap, and Income funds decreased the Churn rate by 10 percentage points or more on the quarterly average during the sample time-period. Growth funds experienced the greatest year-to-year swings in holding patterns, but the least overall change between the starting mean of $26.95 \%$ in 2005 to $25.86 \%$ in 2014 , estimating a 12 month average holding period. ${ }^{206}$ Removing growth funds from the view smooths the picture and produces a shape more closely resembling the other measures.

205. To generate a comparable figure to the CRSP Portfolio Turnover Ratio or the Cremers \& Pareek Duration measure, the average quarterly Churn rate would be multiplied by 4 to estimate the yearly turnover.

206. The growth funds' aggregate churn rate declined from 30\% to $28 \%$ between 2005 and 2014 . 
Figure 7

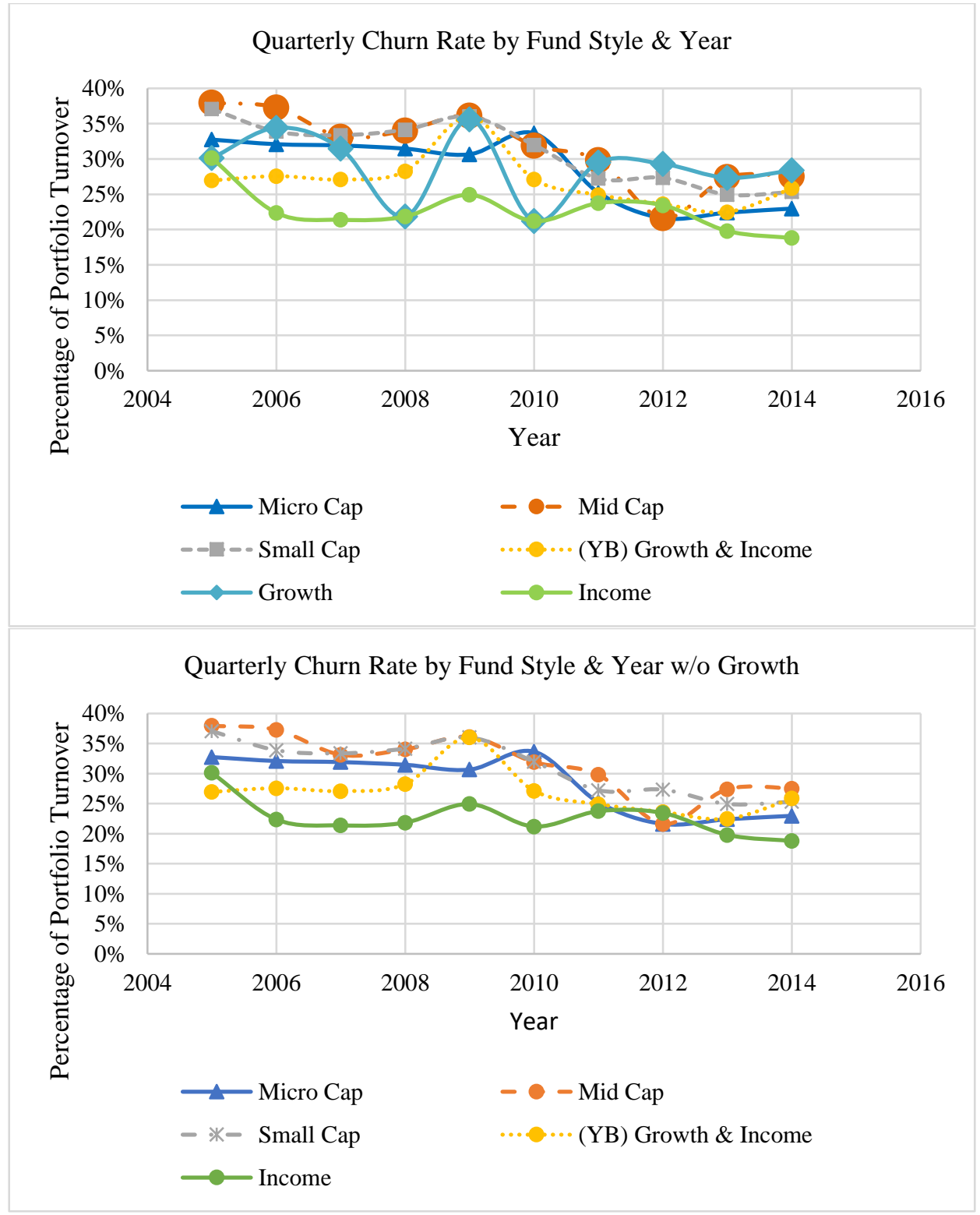

Analyzing mutual fund investment horizons with the Churn Rate evidences fewer portfolio transactions over time. The Churn Rate experienced modest increases (except for Growth funds which spiked) across all funds in 2009 following the financial crisis, in the quarterly averages generating annual estimate trends comparable with the more dramatic changes observed with the annual portfolio turnover ratio and Duration measures. The Churn Rate trend lines suggest more year-to-year variance in transaction 
patterns, especially with Growth fund, which peaks in 2006, 2009 and 2011, but dips in 2008 and 2010. The average holding estimates for Income funds is greater than 15 months, greater than 12 months for Micro funds, and greater than 10 months for Blended, Growth and Mid-cap funds. These estimates are lower and more volatile than the PTR and the other alternative measures examined in this Article.

\section{Modified Turnover Rate}

The third alternative measure to portfolio turnover ratios is the Champagne et al. Modified Turnover (MT) measure. ${ }^{207}$ Champagne et al. found a general decrease of funds' MT of $18.84 \%$ in 1991 to $14.01 \%$ at end of $2012 .^{208}$ The MT captures changes in portfolio weights to reflect the active changes by a mutual fund manager rather than capturing mechanical portfolio adjustments driven by stock price fluctuations. ${ }^{209} \mathrm{MT}$ compares, within a given quarter, the actual portfolio weights to the buy-and hold portfolio weights. For example, neither sales and purchases of the same securities (offsetting trades), or new fund inflows allocated to new stock would increase a fund's MT. ${ }^{210}$ New fund inflows disproportionately allocated among the portfolio, fund outflows resulting in a portfolio reduction or adjustments would increase a fund's MT. ${ }^{211}$ The MT measure is bounded between 0 and $1(0-100 \%)$ making the measure more intuitive than other measures in this Article. A MT measure of close to 0 indicates almost no active changes (outside of price fluctuations). ${ }^{212}$ Conversely, an MT measure of 1, or nearly 1 , indicates active management that purged old holdings and replaced them with new investments. ${ }^{213}$ As a rough estimate, a fund's MT of $25 \%$ per quarter translates into an average stock holding time of approximately one year.

The MT calculation avoids the under inclusive critique of the PTR, which excludes round trip trades. Under the PTR, the two transactions that arise when an asset is bought and sold in the same year are recorded as 0 because the measure is the lesser of purchases or sales. Under the MT, both the purchase and the sale would be recorded. ${ }^{214}$

This measure assesses portfolio activity by applying a weight, ${ }^{215}$ which equals half of the sum of the absolute differences between the quarter $t$ weights of the actual and buy-and-hold equity ${ }^{216}$ portfolios of a mutual fund. ${ }^{217}$

207. Champagne et al., supra note 76 , at 10

208. Id. at 13. Champagne et al. demonstrated a correlation between rising MT (more churning) and falling performance (returns) and falling fund flows (fund investors leaving). Id. at 24-25.

209. Id. at 11 .

210. Id. at 47 .

211. Id.

212. Champagne et al., supra note 76 , at 10 .

213. Id.

214. Id. To avoid bloat, the sum of transactions in MT is divided by 2 .

215. Mark M. Carhart, On Persistence in Mutual Fund Performance, 52 J. Fin. 57, 67 (1997) introduced a similar, but distinct measure to the modified turnover proposed by Champagne et al. The Carhart measure separated the effects of buy and sell trading over fund flow as measured by the percentage change in TNA adjusted for investment returns and measures and found a negative relationship between modified turnover and performance. $I d$.

216. Other asset classes are excluded from this calculation as a measure of portfolio activity. Champagne et al., supra note 76, at 10.

217. Id. at 10 . 


$$
\begin{gathered}
\text { Modified Turnover } \mathrm{j}_{\mathrm{j}, \mathrm{t}}=\frac{1}{2} \sum_{\mathrm{i}=1}^{\mathrm{N}_{\mathrm{j}}}\left|\omega_{\mathrm{i}, \mathrm{t}}^{\mathrm{observed}}-\omega_{\mathrm{i}, \mathrm{t}}^{\mathrm{BH}}\right| \quad(1)^{218} \\
\omega_{\mathrm{i}, \mathrm{t}}^{\mathrm{BH}}=\omega_{\mathrm{i}, \mathrm{t}-1}^{\mathrm{observed}}\left(\frac{1+\mathrm{R}_{\mathrm{it}}}{1+\mathrm{R}_{\mathrm{j}, \mathrm{t}}^{\mathrm{BH}}}\right)
\end{gathered}
$$

In this equation, $\omega_{i, t}^{o b s e r v e d}$ is the weight of stock $i$ as reported in fund $j$ at quarter end $t$. The buy-and-hold weight of stock $i$ at quarter-end $t^{219}$ is represented as $\omega_{i, t}^{B H}$. The total stocks held by fund $j$ is $N_{j}$. $R_{i t}$ is the return of stock $i$ in quarter $\mathrm{t}$, and $R_{j, t}^{B H}$ is the buy-and-hold portfolio return of fund $j$ in quarter $t$ and is computed by:

$$
\mathrm{R}_{\mathrm{j}, \mathrm{t}}^{\mathrm{BH}}=\sum_{\mathrm{i}=1}^{\mathrm{N}_{\mathrm{j}}} \omega_{\mathrm{i}, \mathrm{t}-1}^{\text {observed }} \mathrm{R}_{\mathrm{it}}
$$

Utilizing the formulas above, I report the MT rate for mutual funds from 2005-15. Consistent with the approach used with other measures, I converted the quarterly MT rates to an average rate for each quarter of a year, and report the averages in Appendix 4.

\section{a. General MT Trends}

The mean of the quarterly MT measure for all funds was $17.78 \%, 18.93 \%$ for all active funds, and $12.20 \%$ for all index funds. A mean turnover of $17.78 \%$ for all funds translates into a fund completely changing the fund's holdings over a 17 -month period. ${ }^{220}$ Table 8 shows the distribution of the 2005-2014 Modified Turnover measure mean by standard deviation (Sd) and quartiles (p25, p50, and p75). Appendix 5 graphs the average 2005-14 mean MT distribution for the dataset, as well as by-year MT mean distributions. Table 8 shows the median MT of index funds is $6.83 \%$ compared with $16.33 \%$ in actively managed funds. As noted above, the bounded $0=100 \%$ nature of the MT measure creates a distribution different from the other measures.

218. Equation 1 includes a 0.5 multiplication to restrict the range of the modified turnover to between 0 and 1. Id.

219. Starting at quarter-end $t-1$ weights.

220. The quarterly churn rate of $17.78 \times 4$ quarters generates an annual rate of $71.2 \% .100 / 71.2=1.406 ; 1.406$ $\mathrm{x} 12$ months $=16.82$ months. Champagne et al. reported 14.01 month holding pattern at the end of 2012 using the same calculation, but not the same dataset. Champagne et al., supra note 76, at 13. 
Table 8: Quarterly Modified Turnover 2005-2014 Mean Distribution ${ }^{221}$

\begin{tabular}{|c|c|c|c|}
\hline Metrics & $\begin{array}{c}\text { Mturnover All } \\
\text { Funds }\end{array}$ & $\begin{array}{c}\text { Mturnover } \\
\text { Index Funds }\end{array}$ & $\begin{array}{c}\text { Mturnover Active } \\
\text { Funds }\end{array}$ \\
\hline Mean & $17.78 \%$ & $12.20 \%$ & $18.93 \%$ \\
\hline Sd & 0.1257568 & 0.137575 & 0.1200161 \\
\hline Count & 58997 & 10060 & $10.51 \%$ \\
\hline $\mathrm{p} 25$ & $8.99 \%$ & $2.88 \%$ & $16.33 \%$ \\
\hline $\mathrm{p} 50$ & $15.22 \%$ & $6.83 \%$ & $24.10 \%$ \\
\hline $\mathrm{p} 75$ & $23.27 \%$ & $16.82 \%$ & \\
\hline
\end{tabular}

Between 2005-15, all funds and active funds decreased their MT rate. For all funds and active funds, two other points of note: they both experienced a modest spike in turnover rates in 2009 and experienced a noticeable low in 2013. Index funds, on the other hand, increased between 2005-14, peaking in 2009 and 2010. Differences between active and index funds were more noticeable under the MT measure. The MT measure was less than $25 \%$ in all categories, supporting that, on average, funds are not completely turning over their portfolios within one year.

\section{Figure 8}

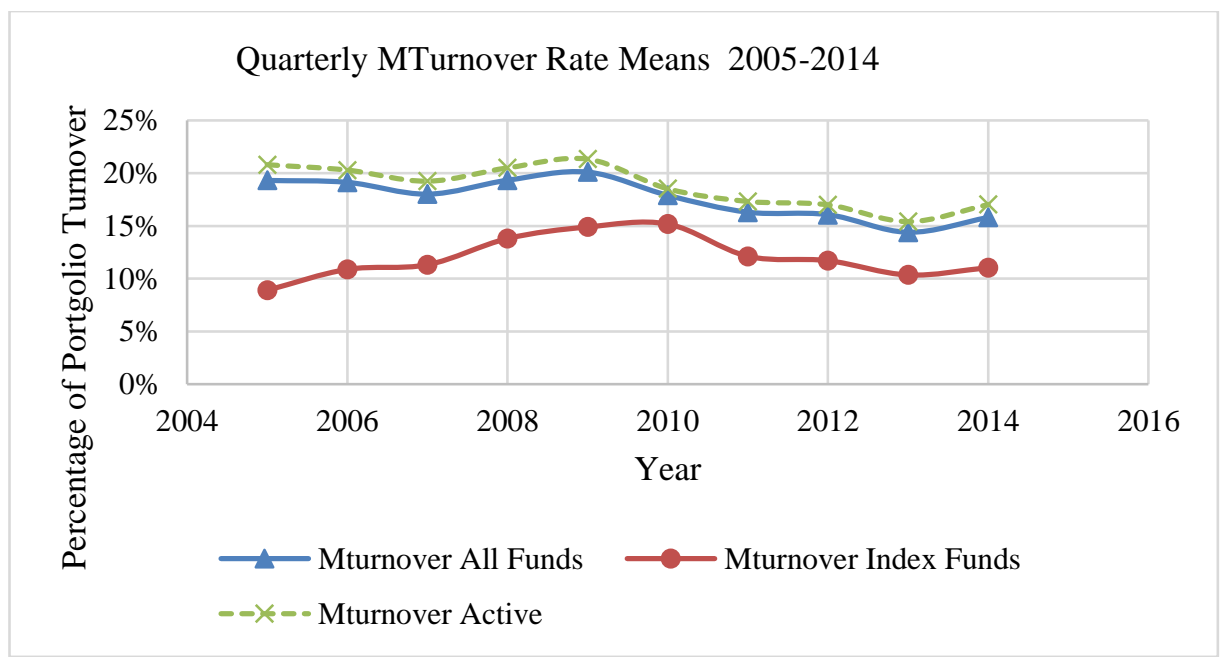

221. Table 8 lists the Mean, the Standard Deviation ( $\mathrm{Sd}$ ), the number of observations (Count), and the quartiles of distributions at $25 \%(\mathrm{p} 25), 50 \%$ (p50), and $75 \%(75 \%)$. 


\section{b. MT Trends by Fund Style and Cap Codes}

Data displayed a general decline in MT calculations. Micro, Mid and Small Cap funds experienced a significant decline of six percent or more from 2005-14. The blended fund (Growth \& Income) remained virtually flat for the 10-year period when looking at 2005 and 2014 numbers, but experienced a four percentage point swing between 2009-13. All fund categories, except Micro-cap funds, experienced a spike in 2009 following the financial crisis.

\section{Figure 9}

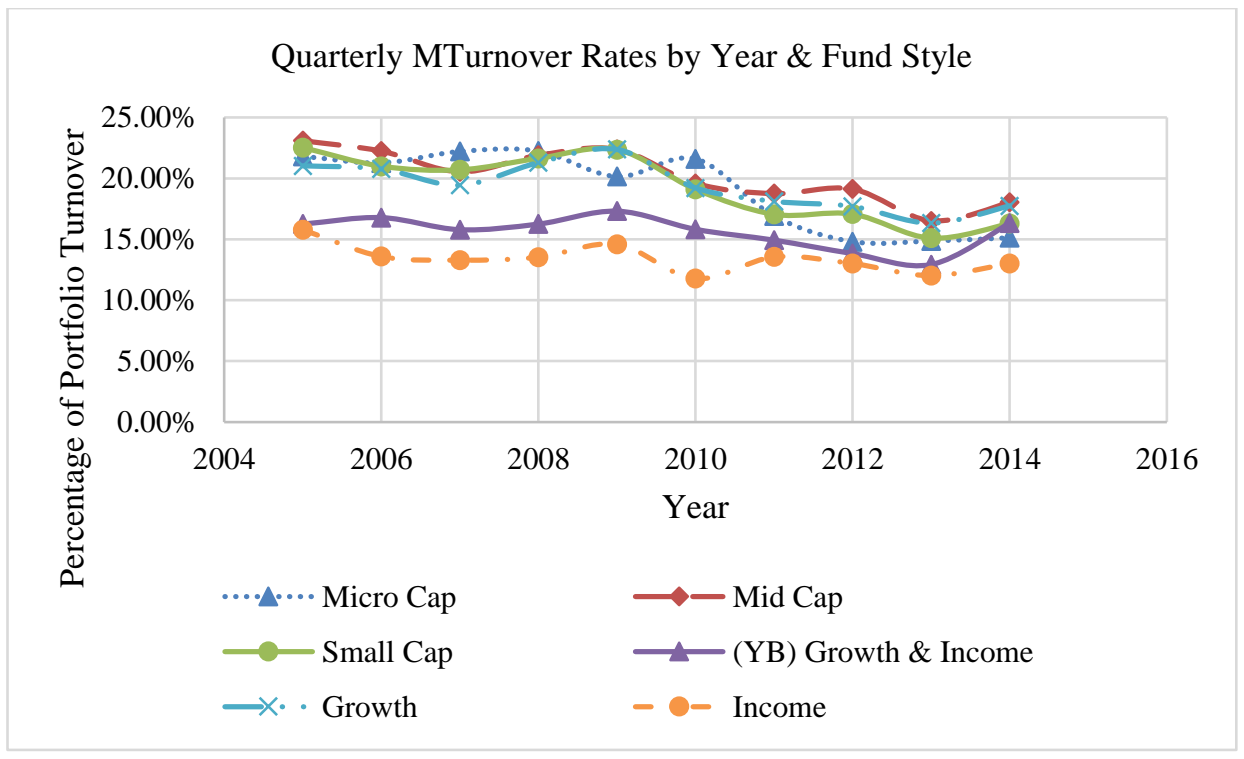

The MT ratio produces a (mostly) declining assessment of fund turnover, or, put another away, demonstrates a decrease in fund transactions. The MT ratio creates a mostly consistent story of decreasing portfolio transactions (except for index funds) observed in all other cuts of the data, and sensitivity to the financial crisis with a modest spike in 2009. The observable increase in MT ratio across all categories from 2013-14 indicates a possible reversal of the trend or chaotic patterns.

\section{DATA DISCUSSION}

\section{A. Average Holding Periods PTR \& Alternative Measures}

Mutual fund holding periods are short - between 10 to 17 months. Three measuresthe PTR, Duration, and MT coalesced around an average mutual fund stock holding time of 15 to 17 months. ${ }^{222}$ The Churn Rate mean estimated shorter holding periods of 10 to 12 months when averaged between 2005-15. The 2014 mean Churn rates, when segmented by fund style, created more consistent estimates of ten to fifteen months

222. As discussed above, the average under each measure was 10 to 17 months: 15 months under the PTR; 15 months under Duration; 10 to 11 month estimate under Churn Rate; and 17 months under MT. 
depending upon fund style (i.e., income funds estimated greater than fifteen months). Most measures created a consistent story of year-to-year variations, with an observable decline between 2005 and 2015, and observable impact around the financial crisis. Consistency between measures is the key take-away, lending support for the continued reporting of mutual fund PTR in annual SEC filings discussed below. There is a distinction to be made between short holding periods, and shortening holding periods. Public mutual fund data, from 2005-15, does not demonstrate a trend of consistently shortening time horizons over the last ten years. Instead, during the sample time period, portfolio turnover ratio declined, indicating increasing time horizons. This observation must be reviewed in light of historical holding patterns, which in 1972 was $38.2 \%$ suggesting an investment time horizon of over two and a half years. ${ }^{223}$ Holding patterns, when measured by portfolio turnover ratios, have declined over time as the turnover ratios increased, but the bleeding appears to have stopped, slowed, or become chaotic over the last decade.

The empirical observations in this Article add nuance to the short-termism narrative. These findings further our understanding of mutual fund investment time horizon patterns and provides a granular view of within fund segments. In this way, the shorttermism debate should benefit from empirical evidence, precision in claims, and ability to target industry segments with the greatest signs of short-termism. All the measures had a long right tail in their distributions, meaning that there were outlier funds with high turnovers that pulled the mean higher, more so than with a normal distribution on a standard bell curve. The bounded zero to one nature of the MT measure muted skewing so distribution of the MT mean most resembles a standard bell curve. The right tails observed in the dataset were not substantial as few organic distributions match a perfect bell curve without some skewing to the right or left. The main difference between the PTR of active and index funds was in the distribution of the mean, not the mean itself, which was negligible at $79.89 \%$ and $79.35 \%$ respectively. The standard deviation for active funds was 1.15 and 1.6 for index funds with the median PTR for each was $60 \%$ in active funds and $28 \%$ in index funds.

\section{B. Signal Strength: Relationship Between PTR \& Alternative Measures}

Consistent trends between the alternative measures and the PTR reinforce the strength of the PTR. By calculating and comparing three alternative measures of fund turnover, I indirectly test the strength of the PTR signal. Using very broad brush strokes, all calculations suggest that institutional investors are holding their stocks for slightly longer periods of time between 2005-15. In some measures, like Duration, an increased

223. Staff of J. Comm. On Taxation, 101st Cong., Tax Treatment of Short-Term Trading 14 (Comm. Print 1990) (citing Stephen A. Berkowitz \& Dennis E. Logue, The Portfolio Turnover Explosion Explored, J. PortFolio MGMT. (Spring 1987)). One commentator in the mutual fund industry noted that 401(k) plans fiduciary obligations to plan participants may encourage sponsors to update the fund "lineup" offered to employees by removing underperforming funds and adding better performing funds. Plan sponsors have over 8,100 funds to choose from when making these decisions. Large swaths of assets could swap out of one fund into another due to the changes in a 401(k) lineup, causing potentially significant turnover. For example, $64 \%$ of plan sponsors updated their money market fund choices after the SEC passed new money market fund rules in 2014, according to consultant firm Callan Associates. Greg Iacurci, 401(k) Plans Make Big Fund Changes Following New Money Market Rules, INV. NEws (Jan. 25, 2017, 1:36 PM), http://www.investmentnews.com/article/20170125/FREE/170129965/401-k-plans-make-big-fund-changesfollowing-new-money-market-rules. 
trend line captures that stocks are held for more months. For all other measures-CRSP Portfolio Turnover Ratio, the Churn rate, and the Modified Turnover - the percentage of fund stock turnover decreased, signaling longer stock holding patterns in mutual funds. Taken as a whole, there is no evidence from 2005-15 that mutual funds' time horizons are in continued, rapid decline. In this respect, the picture painted by PTR calculations of declining turnover and corresponding longer stock holdings is validated by the alternative measures' consistent trend lines.

All measures display noticeable and similar effects from the financial crisis on mutual fund holdings, particularly evident in 2009. Even in measures specifically designed to negate the effect of fund flows and isolate discretionary fund trading experience a shock following the financial crisis. For example, the MT calculation sought to insulate the number from new fund inflows, but this measure still reflected market disruptions that occurred following the financial crisis.

I tested the strength and the direction (negative or positive) of the relationship between the PTR and the alternative measures using a correlation. To understand the relationship tests, recall that increased PTR, MT, and Churn rates estimate shorter holding periods, where as a decrease in Duration estimates a shorter holding period. If there is a relationship between the measures, then as PTR increases, so too should MT and Churn Rate. But as PTR increases, Duration measure should decrease. The table below depicts the relationships.

Table 9: Hypothesis of Relationship Between Measures \& Tests

\begin{tabular}{|l|l|l|}
\hline Relationship 1 & $\uparrow$ PTR & $\begin{array}{l}\downarrow \text { (estimated) holding } \\
\text { periods }\end{array}$ \\
\hline Relationship 2 & $\uparrow$ MT & $\begin{array}{l}\downarrow \text { (estimated) holding } \\
\text { periods }\end{array}$ \\
\hline Relationship 3 & $\uparrow$ Churn Rate & $\begin{array}{l}\downarrow \text { (estimated) holding } \\
\text { periods }\end{array}$ \\
\hline Relationship 4 & $\begin{array}{l}\downarrow \text { (estimated) holding } \\
\text { periods }\end{array}$ \\
\hline \multicolumn{2}{|l|}{} \\
\hline Test \#1 & If PTR $\uparrow$ so too will MT and Churn Rates \\
\hline Test \#2 & If PTR $\uparrow$ then Duration will $\downarrow$ \\
\hline
\end{tabular}

Using a pairwise correlation, ${ }^{224}$ I found a statistically significant, positive correlation between PTR and the Churn rate $(\mathrm{R}=.52, \mathrm{p}<.001)$ as well as with Modified Turnover Ratio $(\mathrm{R}=.43$ for MT with $\mathrm{p}<.001)$. The relationship between PTR and Duration was statistically significant, and negative $(\mathrm{R}=-.38$ for Duration, $\mathrm{p}<.001)$. I repeated the tests isolating active and index funds, demonstrating statistically significant relationships in the direction expected.

224. There is little variation bewteen the correlation coefficient and the pairwise correlation (where the difference is in how the unmatched pairs are handled). Given the similarity, I report the pairwise correlation. 
Table 10: Correlation of PTR to Alternative Measures

\begin{tabular}{|c|c|c|c|}
\hline \multicolumn{4}{|c|}{ Pairwise Correlation: All Funds } \\
\hline PTR & PTR All Funds & PTR Index Funds & PTR Active Funds \\
& $\mathbf{1 . 0 0 0}$ & $\mathbf{1 . 0 0 0}$ & $\mathbf{1 . 0 0 0}$ \\
\hline Duration & $\mathbf{- 0 . 3 8 9 1}$ & & $\mathbf{- 0 . 4 2 2 8}$ \\
& 0.0000 & 0.0000 & 0.0000 \\
& & & $\mathbf{0 . 5 3 5 3}$ \\
& $\mathbf{0 . 5 2 7 8}$ & $\mathbf{0 . 5 2 6 8}$ & 0.0000 \\
\hline MTurnover & 0.0000 & 0.0000 & $\mathbf{0 . 5 3 0 3}$ \\
& $\mathbf{0 . 4 3 5 0}$ & $\mathbf{0 . 1 8 2 9}$ & 0.0000 \\
\hline TNA_Fund & 0.0000 & 0.0000 & $\mathbf{0 . 0 5 8 4}$ \\
& $\mathbf{0 . 0 6 5 4}$ & $\mathbf{- 0 . 0 8 3 3}$ & 0.0000 \\
\hline
\end{tabular}

A regression analysis further explores the supporting hypothesis that a positive relationship between PTR and the alternative measures reinforces the PTR signal strength, or its continued use a rough proxy for mutual fund time horizons. The test is simple: is there an observable relationship between the different measures? To put this is statistical terms, the null hypothesis is that there is no relationship and the alternative hypothesis is that there is a relationship. Regression provides a useful tool.

As between the PTR and the Duration measure, the null hypothesis (no relationship) can be rejected at any confidence level. There is an observable (and predicted) negative correlation between the PTR and Duration measures so that if the PTR increases (mutual fund holding time decreases), the Duration measure decreases (shortening of mutual fund holding times). Similarly, the null hypothesis of no relationship between PTR and Churn Rate and PTR and MT can also be rejected at any confidence level. There is a positive correlation between the PTR and Churn Rate as well as with the MT so that if PTR increases (holding times decreasing) then the alternative measures increase (holding time decreasing). The results reported are for all funds. The results retain statistical significance when segmented for active versus index funds, and when controlled for fixed effects within the regression and robust standard errors. See Appendix 6 for additional statistical outputs. 
Table 11: PTR Linear Regression All Funds

\begin{tabular}{|c|c|c|c|}
\hline VARIABLES & $\begin{array}{c}\text { Dependent Variable: } \\
\text { PTR }\end{array}$ & Constant & $\begin{array}{c}\text { Observations } \\
\text { R-squared }\end{array}$ \\
\hline \multirow{2}{*}{ Duration } & $\mathbf{- 0 . 0 6}^{* * *}$ & $1.64 * * *$ & 62,559 \\
\cline { 2 - 4 } & $(0.001)$ & $(0.009)$ & 0.151 \\
\hline \multirow{2}{*}{ Churn Rate } & $\mathbf{3 . 1 8} * * *$ & $-0.12 * * *$ & 54,067 \\
\cline { 2 - 4 } & $(0.022)$ & $(0.008)$ & 0.279 \\
\hline \multirow{2}{*}{ M Turnover } & $\mathbf{4 . 6} * * *$ & 0.00 & 53,956 \\
\cline { 2 - 4 } & $(0.041)$ & $(0.009)$ & 0.189 \\
\hline \multicolumn{2}{|c|}{$\begin{array}{c}\text { Standard errors in parentheses } \\
* * *\end{array}<0.01, * * \mathrm{p}<0.05, * 0.1$} \\
\hline
\end{tabular}

The consistency between the trends line could be attributed to the common input into each calculation. The alternative measures, however, were each constructed to account for some criticism, shortcoming or bluntness of the portfolio turnover ratio.

To understand the overall time horizon trends observed, I also explored the linear relationship between total net assets (TNA) of the fund (fund size) and the measures. As PTR increased (shorter time horizon), TNA decreased; as Duration increased (longer time horizon), TNA increased; as Churn rate increased (shorter time horizon), TNA decreased; and as MTurnover increased (shorter time horizon), TNA decreased. All relationships were statistically significant at the 99\% confidence level and held for active and index (passive) fund segmenting. In other words, as the fund size increased, all measures reflected longer holding periods through an increased Duration measure and decreased PTR, Churn rate, and MT. Distilled even further, the take away is that there is an observable relationship between the fund size and the holding periods, with larger funds being associated with longer stock holding periods. The effects were largest with actively managed funds. The statisical results are reported in Appendix $6 .{ }^{225}$

\section{Limitations of Empirical Observations}

Any discussion of the mutual fund portfolio turnover and stock holding patterns derived from this study must be framed by the limitations of the dataset. First, an 11-year review is insufficiently short. It also included the financial crisis, to which the securities market as a whole had a strong, negative reaction, ${ }^{226}$ and which generated an observable shock to all measures by some, if not all, fund segments. There is also an element of chaotic variation year to year suggesting the complexity and multiplicity of factors driving turnover, such as liquidity, fund flows, strategy, and discretion. In light of this, perhaps a

225. Infra Appendix 6.

226. Tom Huddleston Jr., These Were the Dow's 10 Worst Single Day Losses Ever, ForTunE FIN. (Aug. 24, 2015), http://fortune.com/2015/08/24/stock-market-august-decline/ (noting largest single-day stock market point drops occurred on September 29 and October 15, 2008). 
better approach for future work, will expand the sample to prior decades and look at fiveyear benchmarks instead of year-to-year trends to observe more macro-level trends.

\section{Mutual Fund Turnover Report \& Time Horizon Estimate Recommendations}

My findings suggest that the PTR is an adequate estimator of transaction frequency and time horizons given its consistency with three other measures. Despite the bluntness of the PTR and other criticisms in Part III, it produced consistent time estimates. The PTR calculation is a simple calculation. It poses a low administrative burden for funds to calculate and report to the SEC as compared to Duration, Churn Rates, or MT measures.

Any endorsement of the current use of the PTR is tempered with an observation about the Duration measure. Further, academic and policy work should incorporate the Duration measure because it is direct, precise, and integrates investor heterogeneity in time horizons. The Duration measure was also the least sensitive to market shocks-like the financial crisis-because it incorporates five years of historical data. The Duration measure's sensitivity to active versus index fund activity will also contribute to a better understanding of mutual fund investment time horizons and corresponding pressures felt by operating company boards. Duration, however, presents too great of an administrative burden to warrant inclusion in the SEC filings given the consistent estimates with the PTR. Additionally, the Duration measure is not intended to capture transaction costs, rendering SEC filings less informative if Duration replaced the PTR in prospectus filings.

\section{CONCLUSION}

The aim of this Article is to observe mutual fund transaction patterns between 20052015 and to test the strength of the PTR signal as an estimate of investment time horizons. Recall the narrative - gleaned from legal literature and policy - that began this Article: institutional investors, like mutual funds, are increasingly short-term orientated and their short-term focus contaminates operating company boards, forcing them to be more shortterm.

This study contributes to our understanding of mutual fund investment time horizons in two key ways. First, there is no empirical evidence of increasing mutual fund turnover between 2005-15 and therefore no support for the claim that mutual funds, as an industry, are increasingly short-term. Across all measures, investment time horizons increased. Second, the PTR produces an adequate estimate of mutual fund time horizons.

How do these findings interact with the short-termism debate? The narrative of contagious mutual fund short-termism is weakened. It has not, however, been dealt a death blow. Perhaps, the damage has already been done. Historically, mutual fund transaction frequency has increased and time horizons shrunk. Second, that a trend of increasing shorttermism is not uniformly observable in the dataset does not eliminate the possible contagion effect of some institutional investors exerting palpable pressure on company boards. Mutual funds may participate, but no clear causal line can be drawn for the industry as a whole. Third, the threat of mutual fund exit, in light of large ownership positions, could be powerful, even if not always acted upon. Fourth, my empirical observations do not discount the power of benchmarks, like quarterly earnings and projections, which funds rely on to formulate exit strategies and manage fund assets. Those benchmarks likely reinforce a short-term performance priority. Fifth, recasting the short-termism narrative to 
incorporate current empirical data sharpens the focus of the debate requiring additional investigation to pinpoint the sources of short-termism. The role of mutual funds in shorttermism requires further empirical investigation, especially in light of data observations in this project.

Finally, examining mutual fund behavior and discussing potential externalities is critically important to the 93 million Americans invested in mutual funds, primarily through tax-deferred retirement accounts. Mutual funds are both major market participants and the primary vehicles through which we save for retirement. Theoretical and empirical investigations are needed to promote individual financial security and systemic stability. 


\section{APPENDICES}

\section{A. Appendix 1: Top 10 Public Companies by Market Capitalization \& Top 10 Institutional Holders}

The top ten market capitalization companies include: Apple (\$806 B), Alphabet (Google) (\$676 B), Microsoft (\$608 B), Facebook (\$497 B), Amazon (\$467 B), Berkshire Hathaway (\$432 B), Johnson \& Johnson (\$385 B), Exxon Mobil (\$ 352 B), JP Morgan Chase (\$349 B), Bank of America (\$286 B). ${ }^{227}$ Mutual fund ownership dominates the top institutional shareholders of these companies. Vanguard funds are the top institutional shareholder in nine out of ten companies (combined ownership ranging from $7.47 \%$ to $5.88 \%$ ). Blackrock funds are the second top institutional shareholder in nine out of ten companies (combined ownership ranging from $6.63 \%$ to $4.98 \%$ ). Northern Trust is a top ten shareholder in nine of the ten companies (combined ownership ranging from $1.39 \%$ to $0.95 \%$ ). Fidelity Research Management (FMR) is a top ten shareholder in eight out of ten companies (combined ownership ranging from $4.02 \%$ to $1.46 \%$ ). State Street Funds is a top ten shareholder in eight of the ten funds (combined ownership ranging from $5.87 \%$ to $3.38 \%$ ). Price (T. Rowe) is a top ten shareholder in five of the top ten companies (combined ownership ranging from $3.65 \%$ to $1.39 \%){ }^{228}$

\section{B. Appendix 2: Count \& Analysis of PTR in Literature}

\begin{tabular}{|l|l|}
\hline Total Sources & 91 \\
\hline Dates & $1990-2016$ \\
\hline Law Articles & 34 \\
\hline Finance \& Related Field Articles & 33 \\
\hline Industry Papers & 11 \\
\hline Interdisciplinary Articles & 2 \\
\hline Other Sources & 0 \\
\hline Coding Results for Sources & \\
\hline Shareholder question & 38 \\
\hline Portfolio turnover ratio as evidence of short-termism & 23 \\
\hline Disclosures on turnover & 3 \\
\hline Costs of turnover and relationship to fees and returns & 12 \\
\hline Portfolio turnover as estimate of transaction costs & 9 \\
\hline Criticisms with the Portfolio turnover calculation & 9 \\
\hline General discussion of turnover & 2 \\
\hline Positive benefits of turnover and/or short-termism & 4 \\
\hline Calculations of Turnover and alternative measures & 6 \\
\hline Other & 20 \\
\hline
\end{tabular}

227. Kenneth Kiesnoski, The Top 10 US Companies by Market Capitalization, CNBC MONEY (Oct. 24, 2017), https://www.cnbc.com/2017/03/08/the-top-10-us-companies-by-market-capitalization.html.

228. Figures pulled from Yahoo Finance and calculations on file with author. 
C. Appendix 3: PTR Sources in the Congressional Record by Hearing \& Date

\begin{tabular}{|l|l|l|}
\hline 1. & Legislative Record & Dates \\
\hline & $\begin{array}{l}\text { Pension Funds in the Capital } \\
\text { Markets: Hearing before the } \\
\text { Subcommittee on } \\
\text { Telecommunications, Consumer } \\
\text { Protection \& Finance of the } \\
\text { House Committee on Energy } \\
\text { and Commerce, 99th Congress, } \\
\text { Serial No. 99-92 }\end{array}$ & \\
\hline $\begin{array}{ll}\text { Attached Study: Study of the } \\
\text { Investment Performance of }\end{array}$ & \\
$\begin{array}{l}\text { ERISA Plans Prepared for the } \\
\text { Office of Pension and Welfare } \\
\text { Benefits: Department of Labor, } \\
\text { Contract Number J-9-P-4-0109 }\end{array}$ & \\
\hline 2. & $\begin{array}{l}\text { The Impact of Institutional } \\
\text { Investors on Corporate } \\
\text { Governance, Takeovers, and the } \\
\text { Capital Markets: Hearing before } \\
\text { the Subcommittee on Securities } \\
\text { of the Senate Committee on } \\
\text { Banking, Housing and Urban } \\
\text { Affairs, 101st Congress }\end{array}$ & \\
\hline $\begin{array}{l}\text { Attached Study: Institutional } \\
\text { Investors and Corporate } \\
\text { America: Conflicts and } \\
\text { Resolutions: An Overview of the } \\
\text { Role of Institutional Investors in } \\
\text { Capital Markets and Corporate } \\
\text { Governance prepared for the } \\
\text { Subcommittee by Dr. Carolyn } \\
\text { Kay Brancato }\end{array}$ & \\
\hline 3. & $\begin{array}{l}\text { Effects of Short-Term Trading } \\
\text { on Long-Term Investments: } \\
\text { Hearing on S.1654 and S. 2160 } \\
\text { before the Senate Committee on } \\
\text { Finance, 101 st Cong. }\end{array}$ & \\
\hline $\begin{array}{l}\text { Attached study: Tax Treatment } \\
\text { of Short-term Trading prepared } \\
\text { by the Staff of the Joint } \\
\text { Committee on Taxation Hearing } \\
\text { before the Subcommittee on } \\
\text { Capital Markets, Insurance and } \\
\text { Government Sponsored } \\
\text { Enterprises of the Committee on }\end{array}$ & \\
\hline
\end{tabular}




\begin{tabular}{|l|l|l|}
\hline & Financial Services, Serial No. & \\
$108-11$
\end{tabular}


D. Appendix 4: Annual Mutual Fund Data by Measures \& Years

\begin{tabular}{|c|c|c|c|c|c|c|}
\hline YEAR & $\mathbf{2 0 0 5}$ & $\mathbf{2 0 0 6}$ & $\mathbf{2 0 0 7}$ & $\mathbf{2 0 0 8}$ & $\mathbf{2 0 0 9}$ & $\mathbf{2 0 1 0}$ \\
\hline Duration all & 14.11 & 13.96 & 14.47 & 14.72 & 14.18 & 14.44 \\
\hline Index Dur & 23.9 & 23.04 & 22.21 & 21.85 & 18.45 & 18.07 \\
\hline Active Dur & 12.85 & 12.66 & 13.51 & 13.44 & 13.21 & 13.59 \\
\hline $\begin{array}{c}\text { Churn Rate } \\
\text { all }\end{array}$ & $33.90 \%$ & $32.10 \%$ & $30.20 \%$ & $31.70 \%$ & $33.40 \%$ & $30.60 \%$ \\
\hline Index CR & $23.90 \%$ & $23.40 \%$ & $24.62 \%$ & $28.76 \%$ & $29.19 \%$ & $30.65 \%$ \\
\hline Active CR & $34.40 \%$ & $33.30 \%$ & $31.23 \%$ & $32.45 \%$ & $34.45 \%$ & $30.61 \%$ \\
\hline PTR All & $84.90 \%$ & $81.20 \%$ & $81.40 \%$ & $85.70 \%$ & $99.60 \%$ & $87.60 \%$ \\
\hline Index PTR & $85.10 \%$ & $72.04 \%$ & $69.20 \%$ & $76.10 \%$ & $101.70 \%$ & $93.10 \%$ \\
\hline Active PTR & $84.90 \%$ & $82.70 \%$ & $83.60 \%$ & $87.64 \%$ & $99.20 \%$ & $86.35 \%$ \\
\hline Mturnover all & $19.3 \%$ & $19.1 \%$ & $18.0 \%$ & $19.3 \%$ & $20.1 \%$ & $17.9 \%$ \\
\hline Index MT & $8.90 \%$ & $10.88 \%$ & $11.32 \%$ & $13.80 \%$ & $14.90 \%$ & $15.18 \%$ \\
\hline Active MT & $20.80 \%$ & $20.29 \%$ & $19.24 \%$ & $20.50 \%$ & $21.33 \%$ & $18.52 \%$ \\
\hline TNA all & 1069 & 1204 & 1341 & 1032 & 950 & 1233 \\
\hline Index TNA & 1858 & 2041 & 2282 & 1775 & 1575 & 2180 \\
\hline Active TNA & 950 & 1069 & 1179 & 892 & 813 & 1026 \\
\hline
\end{tabular}

\begin{tabular}{|c|c|c|c|c|c|}
\hline YEAR & $\mathbf{2 0 1 1}$ & $\mathbf{2 0 1 2}$ & $\mathbf{2 0 1 3}$ & $\mathbf{2 0 1 4}$ & $\mathbf{2 0 1 5}$ \\
\hline Duration all & 15.27 & 16.29 & 16.68 & 17.39 & \\
\hline Index Dur & 19.43 & 19.78 & 20.25 & 21.33 & \\
\hline Active Dur & 14.29 & 15.45 & 15.81 & 16.44 & \\
\hline Churn Rate all & $27.40 \%$ & $26.90 \%$ & $24.80 \%$ & $25.70 \%$ & \\
\hline Index CR & $24.55 \%$ & $22.00 \%$ & $21.03 \%$ & $21.64 \%$ & \\
\hline Active CR & $28.09 \%$ & $27.90 \%$ & $25.70 \%$ & $26.74 \%$ & \\
\hline PTR All & $76.60 \%$ & $73.40 \%$ & $68.10 \%$ & $65.10 \%$ & $62.80 \%$ \\
\hline Index PTR & $75.10 \%$ & $74.28 \%$ & $77.28 \%$ & $71.23 \%$ & $70.40 \%$ \\
\hline Active PTR & $77.01 \%$ & $73.23 \%$ & $66.00 \%$ & $63.70 \%$ & $61.10 \%$ \\
\hline Mturnover all & $16.3 \%$ & $16.1 \%$ & $14.4 \%$ & $15.8 \%$ & \\
\hline Index MT & $12.12 \%$ & $11.71 \%$ & $10.35 \%$ & $11.04 \%$ & \\
\hline Active MT & $17.32 \%$ & $17.00 \%$ & $15.41 \%$ & $17.02 \%$ & \\
\hline TNA all & 1390 & 1595 & 2100 & 2581 & 2814 \\
\hline Index TNA & 2517 & 1990 & 4360 & 5826 & 6602 \\
\hline Active TNA & 1135 & 1255 & 1573 & 1846 & 1944 \\
\hline
\end{tabular}


E. Appendix 5: PTR Mean Distributions by Measure and by Year
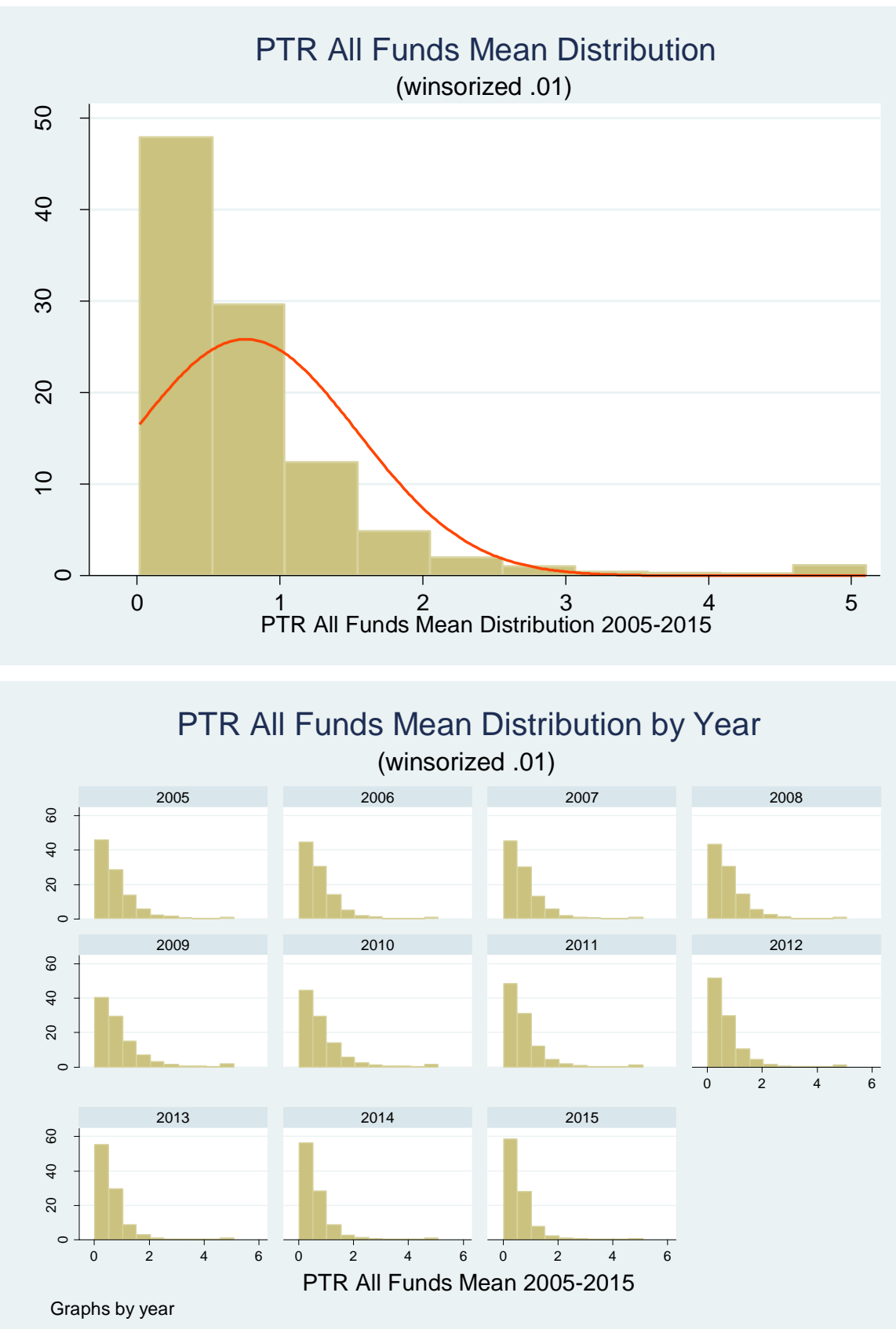

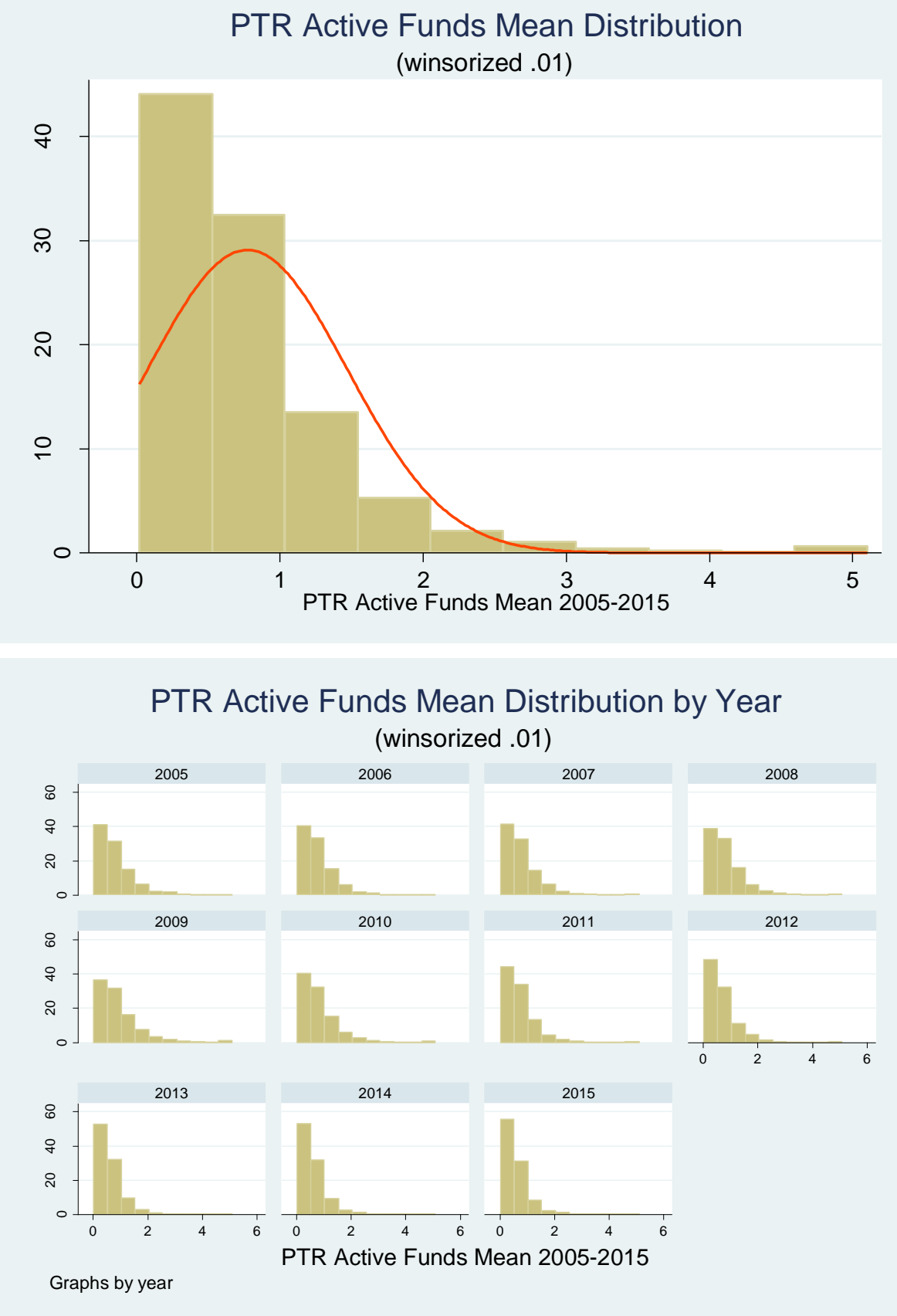

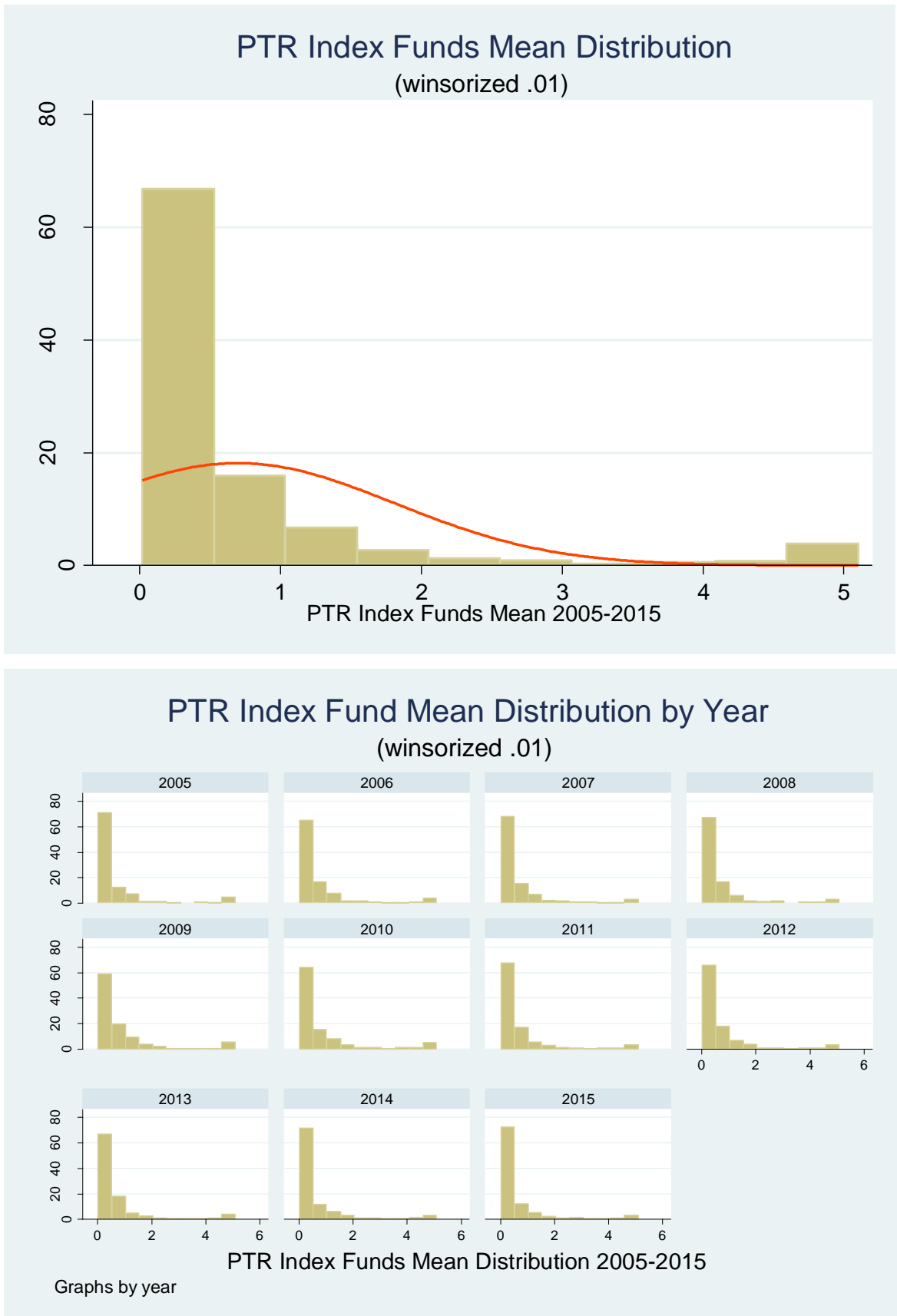


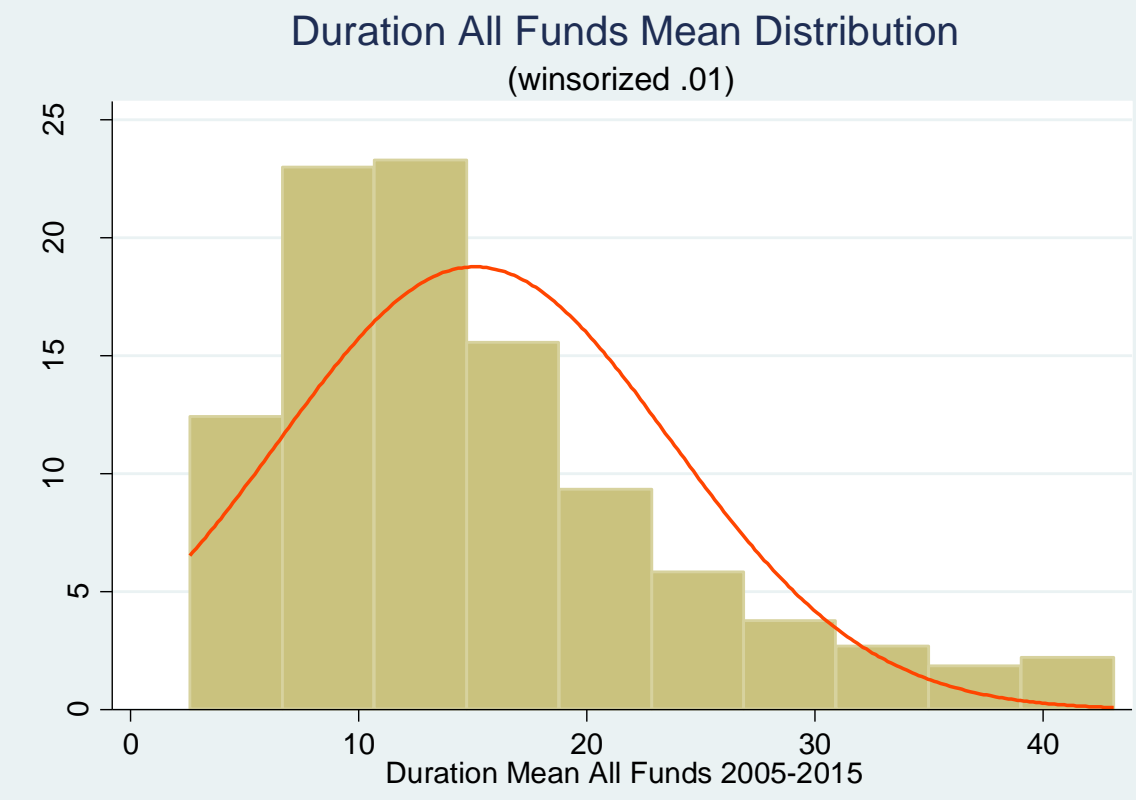

Duration All Funds Mean Distribution by Year (winsorized .01)

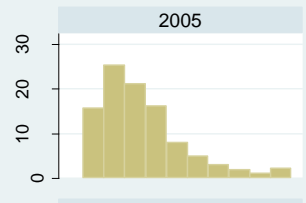

2006

2007 2008
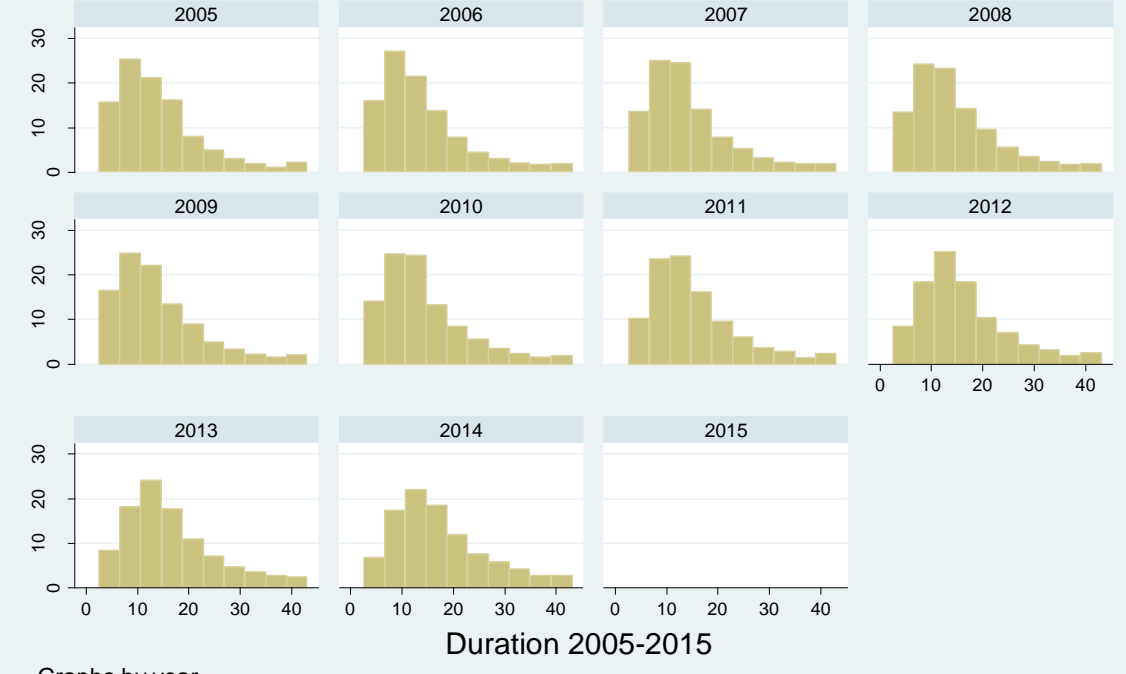

Duration 2005-2015

2015

Graphs by year 

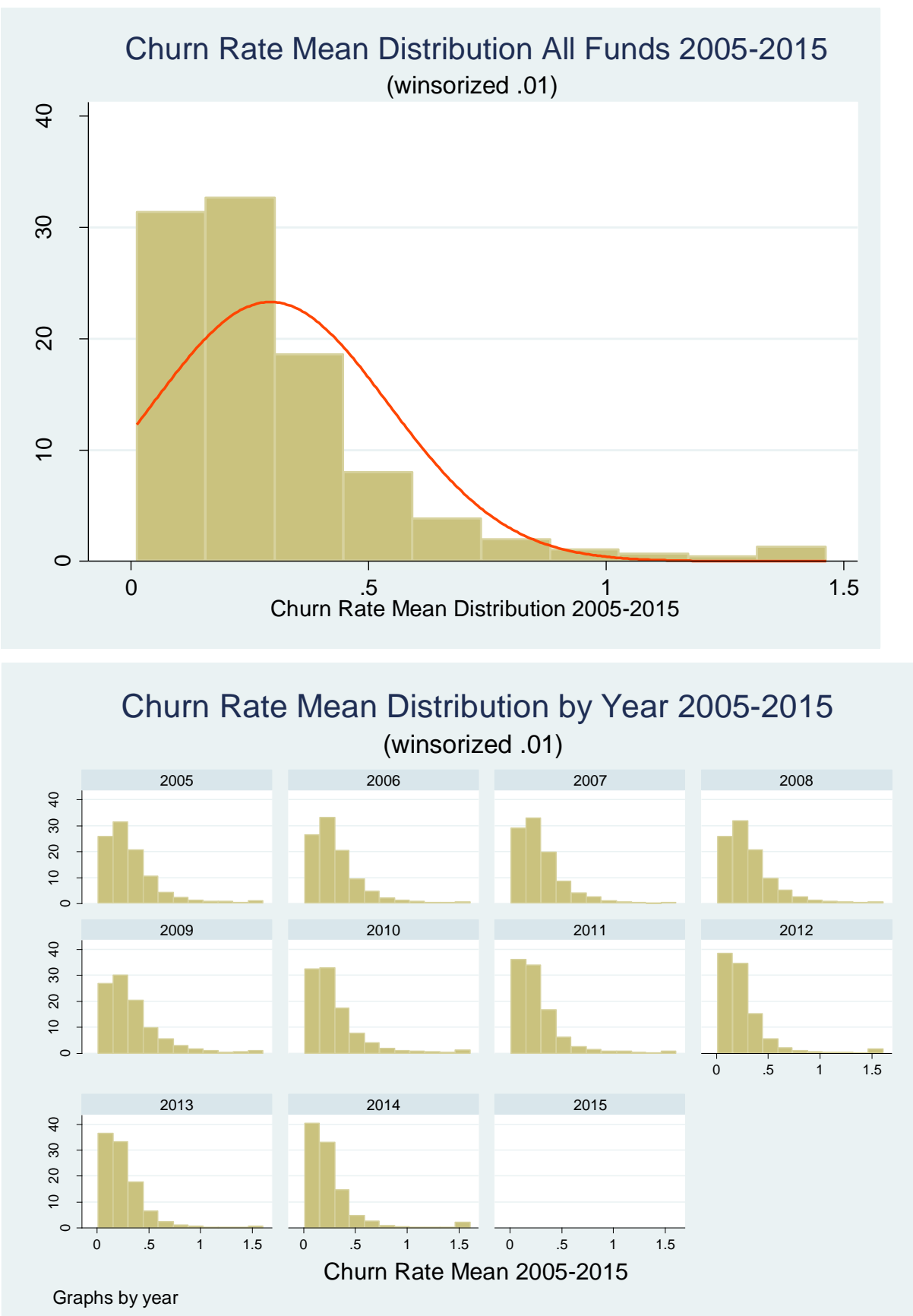


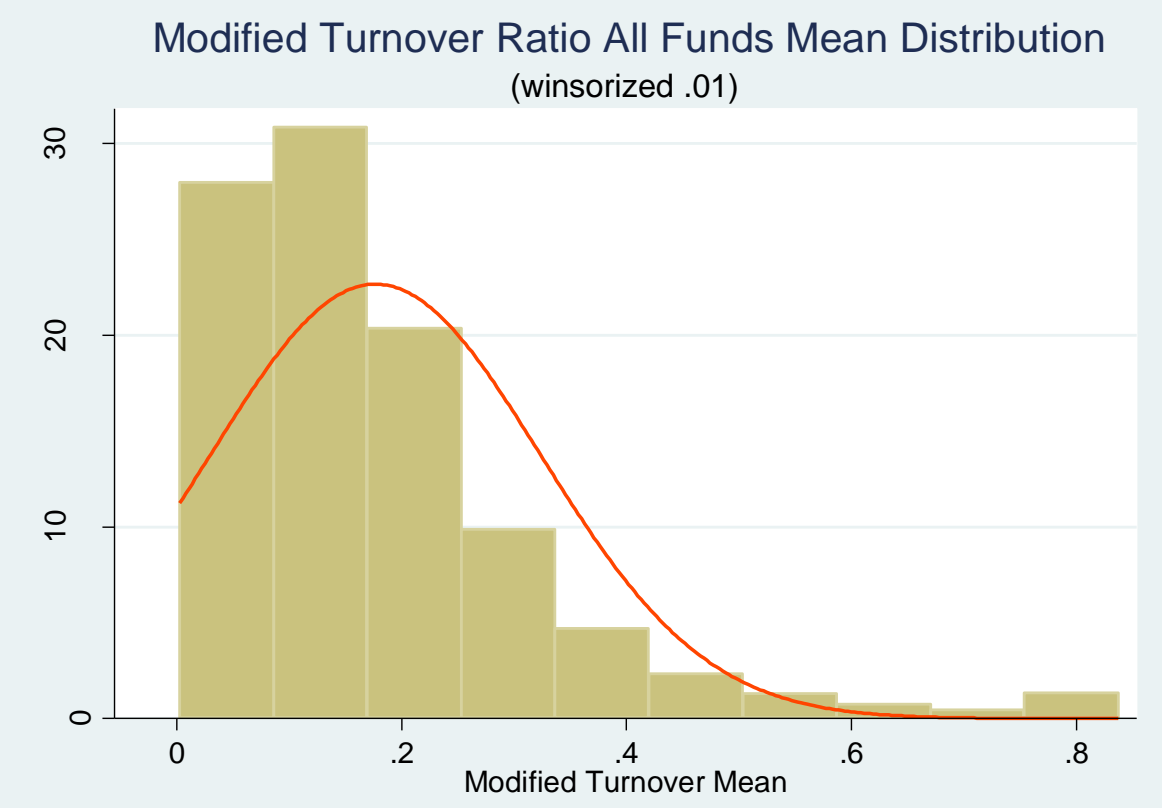

\section{Modified Turnover All Funds Mean Distribution by Year} (winsorized .01)

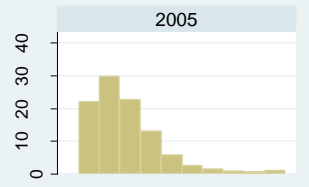

2006

2007

2008

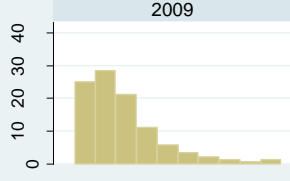

2010

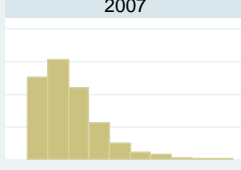

2011

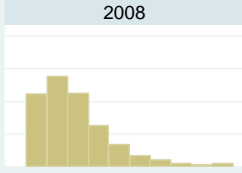

2012

2013
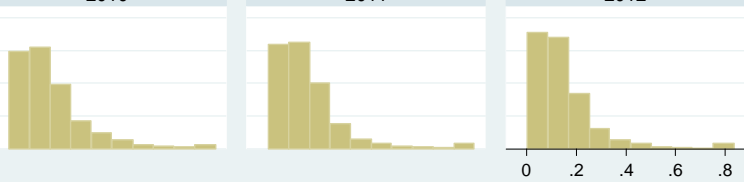

2015

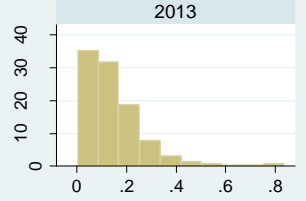

2014

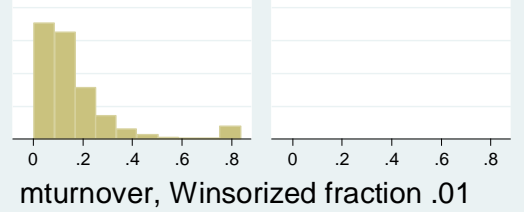

Graphs by year 
F. Appendix 6: Correlation \& Regression Data

\begin{tabular}{|c|c|c|c|}
\hline \multicolumn{2}{|c|}{ PTR Linear Regression Active Funds } \\
\hline VARIABLES & $\begin{array}{c}\text { Dependent Variable: } \\
\text { PTR }\end{array}$ & Constant & $\begin{array}{c}\text { Observations } \\
\text { R-squared }\end{array}$ \\
\hline \multirow{2}{*}{ Duration } & $\mathbf{- 0 . 0 6 * * *}$ & $1.67 * * *$ & 52,229 \\
\cline { 2 - 4 } & $(0.001)$ & $(0.010)$ & 0.156 \\
\hline \multirow{2}{*}{ Churn Rate } & $\mathbf{3 . 0 4} * * *$ & $-0.11 * * *$ & 45,036 \\
\cline { 2 - 4 } & $(0.023)$ & $(0.008)$ & 0.286 \\
\hline \multirow{2}{*}{ M Turnover } & $\mathbf{5 . 4 2 * * *}$ & $0.20 * * *$ & 44,944 \\
\cline { 2 - 4 } & $(0.041)$ & $(0.009)$ & 0.281 \\
\hline & $\begin{array}{c}\text { Standard errors in parentheses } \\
* * *\end{array}<0.01, * * \mathrm{p}<0.05, * \mathrm{p}<0.1$ \\
\hline
\end{tabular}

\begin{tabular}{|c|c|c|l|}
\hline \multicolumn{4}{|c|}{ PTR Linear Regression Index Funds } \\
\hline VARIABLES & $\begin{array}{c}\text { Dependent Variable: } \\
\text { PTR }\end{array}$ & $\begin{array}{l}\text { Constant } \\
\text { R-squared }\end{array}$ \\
\hline \multirow{2}{*}{ Duration } & $\mathbf{- 0 . 0 6 * * *}$ & $1.95 * * *$ & 10,330 \\
\cline { 2 - 4 } & $(0.001)$ & $(0.029)$ & 0.179 \\
\hline \multirow{2}{*}{ Churn Rate } & $\mathbf{3 . 8 0} * * *$ & $-0.14 * * *$ & 9,031 \\
\cline { 2 - 4 } & $(0.065)$ & $(0.022)$ & 0.277 \\
\hline \multirow{2}{*}{ M Turnover } & $\mathbf{2 . 3 5} * * *$ & 0.53 & 9,012 \\
\cline { 2 - 4 } & $(0.133)$ & $(0.024)$ & 0.033 \\
\hline & \multicolumn{2}{|c|}{$\begin{array}{l}\text { Standard errors in parentheses } \\
* * *\end{array}<0.01, * * \mathrm{p}<0.05, * \mathrm{p}<0.1$} \\
\hline
\end{tabular}




\begin{tabular}{|c|c|c|c|}
\hline \multicolumn{4}{|c|}{ PTR Linear Regression Robust Standard Errors } \\
\hline VARIABLES & $\begin{array}{c}\text { Dependent Variable: } \\
\text { PTR } \\
\end{array}$ & Constant & $\begin{array}{c}\text { Observations } \\
\text { R-squared }\end{array}$ \\
\hline \multirow[t]{2}{*}{ Duration } & $\mathbf{- 0 . 0 6} * * *$ & $1.64 * * *$ & 62,559 \\
\hline & $(0.001)$ & $(0.015)$ & 0.151 \\
\hline \multirow[t]{2}{*}{ Churn Rate } & $3.18 * * *$ & $-0.12 * * *$ & 54,067 \\
\hline & $(0.116)$ & $(0.031)$ & 0.279 \\
\hline \multirow[t]{2}{*}{ M Turnover } & $4.60 * * *$ & 0.00 & 53,956 \\
\hline & $(0.168)$ & $(0.027)$ & 0.189 \\
\hline \multicolumn{4}{|c|}{$\begin{array}{l}\text { Standard errors in parentheses } \\
* * * \mathrm{p}<0.01, * * \mathrm{p}<0.05, * \mathrm{p}<0.1\end{array}$} \\
\hline
\end{tabular}

\begin{tabular}{|c|c|c|c|c|}
\hline \multirow{2}{*}{ VARIABLES } & $\begin{array}{c}\text { Dependent } \\
\text { Variable: PTR }\end{array}$ & Constant & $\begin{array}{c}\text { Observations } \\
\text { R-squared }\end{array}$ & Number of yq \\
\hline Duration & $\mathbf{- 0 . 0 6 * * *}$ & $1.64 * * *$ & 62,559 & 40 \\
\cline { 2 - 5 } & $(0.001)$ & $(0.009)$ & 0.151 & \\
\hline Churn Rate & $\mathbf{3 . 1 7} * * *$ & $-0.12 * * *$ & 54,067 & 40 \\
\cline { 2 - 5 } & $(0.022)$ & $(0.008)$ & 0.274 & 40 \\
\hline M Turnover & $\mathbf{4 . 5 8} * * *$ & 0.01 & 53,956 & \\
\cline { 2 - 5 } & $(0.041)$ & $(0.009)$ & 0.185 & \\
\hline \multicolumn{5}{|c|}{$\begin{array}{c}\text { Standard errors in parentheses } \\
* * *\end{array}<0.01, * * \mathrm{p}<0.05, * \mathrm{p}<0.1$} \\
\hline
\end{tabular}




\begin{tabular}{|c|c|c|c|}
\hline VARIABLES & $\begin{array}{c}\text { Dependent Variable: } \\
\text { TNA_Fund }\end{array}$ & Constant & $\begin{array}{c}\text { Observations } \\
\text { R-squared }\end{array}$ \\
\hline PTR All & $\begin{array}{c}-\mathbf{4 0 3 . 3 1 * * *} \\
(20.861)\end{array}$ & $\begin{array}{c}1,878.33 * * * \\
(30.592)\end{array}$ & $\begin{array}{c}86,930 \\
0.004\end{array}$ \\
\hline PTR Active & $\begin{array}{c}-\mathbf{2 5 4 . 1 6} * * * \\
(16.136)\end{array}$ & $\begin{array}{l}1,443.30 * * * \\
(22.703)\end{array}$ & $\begin{array}{l}72,390 \\
0.004\end{array}$ \\
\hline PTR Index & $\begin{array}{c}-\mathbf{7 8 6 . 9 5} * * * \\
(78.072)\end{array}$ & $\begin{array}{c}3,741.63 * * * \\
(135.277)\end{array}$ & $\begin{array}{l}14,540 \\
0.007\end{array}$ \\
\hline \multirow[t]{2}{*}{ Duration All } & $151.94 * * *$ & $-764.47 * * *$ & 65,704 \\
\hline & $(3.297)$ & $(57.607)$ & 0.031 \\
\hline \multirow[t]{2}{*}{ Duration Active } & $98.91 * * *$ & $-121.81 * * *$ & 54,900 \\
\hline & $(2.951)$ & $(46.947)$ & 0.020 \\
\hline \multirow[t]{2}{*}{ Duration Index } & $235.40 * * *$ & $-1,981.92 * * *$ & 10,804 \\
\hline & $(11.290)$ & $(269.692)$ & 0.039 \\
\hline \multirow[t]{2}{*}{ Churn Rate ALL } & $-3,724.52 * * *$ & $2,614.17 * * *$ & 57,250 \\
\hline & $(146.513)$ & $53.669)$ & 0.011 \\
\hline \multirow[t]{2}{*}{ Churn R. Active } & $-2,2281.02 * * *$ & $1,930.12 * * *$ & 47,646 \\
\hline & 111.789) & $(41.368)$ & 0.009 \\
\hline \multirow[t]{2}{*}{ Churn R. Index } & $-7,594.44 * * *$ & $4,759.92 * * *$ & 9,601 \\
\hline & $(601.370)$ & $(208.766)$ & 0.016 \\
\hline \multirow[t]{2}{*}{ M Turnover All } & $-6,562.10 * * *$ & $2,672.36$ & 57.143 \\
\hline & $(248.335)$ & $(54.162)$ & 0.012 \\
\hline \multirow[t]{2}{*}{ M Turnover Active } & $-4,131.19 * * *$ & $2011.54 * * *$ & 47,558 \\
\hline & (191.405) & (142.927) & 0.010 \\
\hline \multirow[t]{2}{*}{ M Turnover Index } & $-12,150.19 * * *$ & $4,348.81 * * *$ & 9,559 \\
\hline & $(1,060.135)$ & (195.527) & 0.014 \\
\hline
\end{tabular}

